\title{
Assessment of Activation Products in the Savannah River Site Environment ${ }^{(U)}$
}

W. H. Carltòn

M. Denham

Approved by:

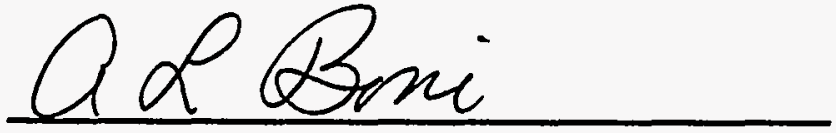

A. L. Boni, Manager

Environmental Technology Section

Prepared for the U.S. Department of Energy under contract no. DE-AC09-89SR18035

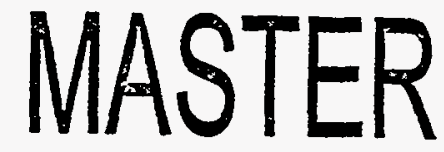





\section{DISCLAIMER}

Portions of this document may be illegible in electronic image products. Images are produced from the best available original document. 



\section{Contents}

Executive Summary i

Chapter 1. Introduction 1-1

Physical Characteristics $1-3$

References 1-3

\section{Chapter 2. Origin and Disposition of Activation Products}

\section{at SRS 2-1}

Origin of Activation Products at SRS 2-3

Irradiation in Production Reactors 2-3

Production of Phosphorus-32 2-3

Production of Chromium-51 2-3

Production of Cobalt-60 2-3

Production of Zinc-51 2-3

Other Sources Attributable to SRS Operations 2-3

SRS Test Reactors 2-3

Spontaneous Fission 2-4

Materials Originating Offsite $2-4$

Disposition of Activation Products at SRS 2-4

Activation Products in Fuel and Targets Irradiated in Production Reactors 2-4

Activation Products in Certain Fuel Irradiated Offsite 2-5

Activation Products in Fuel And Targets Irradiated in Test Reactors 2-5

Activation Products from Spontaneous Fission 2-5

Commercially Purchased Activation Products 2-6

Global-Fallout Activation Products 2-6

References 2-6

\section{Chapter 3. Releases and Stored Inventories of Activation}

Products at SRS 3-1

Reactor Facilities 3-3

Facility Operations 3-3

Pathways for Release 3-3

Emission Control 3-4

Release Monitoring 3-4

History of Measured Releases 3-4

C Reactor 3-5

K Reactor 3-5

L Reactor 3-5

P Reactor 3-18

R Reactor 3-18

Summary of Reactor Releases 3-18 
Separations and Liquid Waste Facilities 3-18

Facility Operations 3-18

Pathways for Release 3-22

Emission Control 3-22

Release Monitoring 3-22

History of Measured Releases 3-22

F-Area Separations 3-22

Releases to Atmosphere 3-23

Releases to Streams 3-23

Releases to F-Area Seepage Basins 3-23

H-Area Separations 3-23

Releases to Atmosphere 3-23

Releases to Streams 3.23

Releases to H-Area Seepage Basins 3-23

Effuent Treatment Facility 3-23

Waste Tank Farms 3-24

Summary of Separations and Liquid-Waste Facilities 3-28

Solid Waste Disposal Facility 3-27

Savannah River Technology Center 3-27

Other Facilities 3-27

References 3-28

\section{Chapter 4. Activation Product Concentration} and Transport Mechanisms 4-1

Atmospheric Transport 4-3

Aqueous Transport 4-3

Surface Waters on the Savannah River Site 4-3

Lower Three Runs Creek 4-3

Upper Three Runs Creek 4-3

Steel Creek 4-3

Fourmile Branch 4-3

Pen Branch 4-4

Site Stream Summary 4-4

Savannah River $4-4$

Groundwater Concentrations and Transport 4-4

SRS Groundwater System 4-4

Activation Products in SRS Groundwater 4-6

Cobalt 60 Chemistry in Groundwater 4-7

Summary 4-8

References 4-8

Chapter 5. Assessment of Dose/Risk from SRS Activation

Product Releases 5-1

Relationship of Dose to Risk and Health Effects 5-3

lonizing Radiation 5-3

Cancer Risk Estimates 5-3

Activation Product Exposure and Dose to Man 5-3 
Models of Activation Product Transport and Dose 5-4

Atmospheric Releases 5-4

Liquid Releases 5-4

Modeling Atmospheric Dispersion of Radioactive Releases 5-4 MAXIGASP 5-6 POPGASP 5-6

Modeling Doses from Liquid Releases $5-6$

Validation of Models Using Monitoring Data 5-9

Atmospheric Releases 5-9

Liquid Releases 5-9

Impact of SRS Activation Product Releases

on the Offsite Population 5-9

Doses from Atmospheric Releases $\mathbf{5 - 1 0}$

Individual Doses from Liquid Releases 5-10

Phosphorus-32 5-10

Chromium-51 5-10

Cobalt-60 5-10

Zinc-65 5-17

Sum of All Doses 5-17

Collective Doses from Liquid Releases 5-17

Comparison of Activation Product Doses Near SRS

with Applicable Regulations 5-17

Atmospheric Releases 5-17

Liquid Releases 5-17

Summary of Dosimețric Impacts 5-18

References 5-18

Additional Reading 5-19

\section{List of Figures}

Figure 2.1. Areas within SRS that may be Sources of Activation

Figure 3.1. Product Releases 2-2

Figure 3.2. Proximity of SRS Facilities to Site Streams 3-2

Figure 3.3. C-Area 32P Releases to Streams and Basins 3-6

Figure 3.4. C.Area ${ }^{51} \mathrm{Cr}$ Releases to Streams and Basins $3-6$

Figure 3.5. C-Area ${ }^{60}$ Co Releases to Streams and Basins 3-7

Figure 3.6. C-Area ${ }^{65} \mathrm{Zn}$ Releases to Streams and Basins 3-7

Figure 3.7. K-Area 32P Releases to Streams and Basins 3-9

Figure 3.8. $\mathrm{K}$-Area ${ }^{51} \mathrm{Cr}$ Releases to Streams and Basins 3-9

Figure 3.9. K-Area ${ }^{60}$ Co Releases to Streams and Basins 3-10

Figure 3.10. K-Area ${ }^{65} \mathrm{Zn}$ Releases to Streams and Basins 3-10

Figure 3.11. L-Area 32P Releases to Streams and Basins 3-12

Figure 3.12. Figure 3.13. Figure 3.14. Figure 3.15. Figure 3.16. Figure 3.17. Figure 3.18. Figure 3.19. Figure 3.20 . L-Area ${ }^{51} \mathrm{Cr}$ Releases to Streams and Basins 3-12 L-Area ${ }^{60}$ Co Releases to Streams and Basins 3-13 L-Area ${ }^{65} \mathrm{Zn}$ Releases to Streams and Basins 3-13 P-Area 32P Releases to Streams and Basins 3-15 P-Area ${ }^{51} \mathrm{Cr}$ Releases to Streams and Basins 3-15 P-Area ${ }^{60}$ Co Releases to Streams and Basins 3-16 P-Area ${ }^{65} \mathrm{Zn}$ Releases to Streams 3-16 R-Area 32P Releases to Streams and Basins 3-19

Figure 3.21. R-Area ${ }^{51} \mathrm{Cr}$ Releases to Streams and Basins 3-19 R-Area ${ }^{60}$ Co Releases to Streams and Basins 3-20 R-Area ${ }^{65} \mathrm{Zn}$ Releases to Streams 3-20 
Figure 3.22.

Figure 3.23.

Figure 3.24.

Figure 3.25 .

Figure 4.1.

Figure 4.2.

Figure 4.3.

Figure 4.4.

Figure 4.5 .

Figure 4.6.

Figure 5.1.

Figure 5.2.
H-Area ${ }^{51} \mathrm{Cr}$ Releases to Basins 3-25

H-Area ${ }^{60}$ Co Releases to Basins 3-25

H-Area ${ }^{65} \mathrm{Zn}$ Releases to Basins 3-26

SRTC ${ }^{60}$ Co Releases to Atmosphere $3-26$

Geological Cross-Section Showing the Main

Aquifers 4-5

\section{Stratigraphicand Hydrostratigraphic Nomenclature} Used at SRS 4-5

Updip Limits of the Confining Systems in the Coastal Plain Sediments 4-6

Hydraulic Head Differences Across Confining Units

Near the Cretaceous/Tertiary Boundary $4-6$

Location Map of Waste Disposal Sites Near F Area and $H$ Area 4-7

Time Series Plot Showing ${ }^{60}$ Co Activities in Groundwater from the Five Wells that have Exceeded the Drinking Water Standard. The Heavy Solid Line is the Decay Curve of ${ }^{60} \mathrm{Co}$ from the Maximum Activity of $210 \mathrm{pCi} /$ liter, the Dashed Line is the Drinking Water Standard of $100 \mathrm{pCi} /$ liter. 4-8 Simplified Pathways between Radioactive Materials Released to the Atmosphere and Man 5-5

Simplified Pathways between Radioactive Materials Released to Groundwater or Surface Waters and Man 5-8

\section{List of Tables}

Table 1-1.

Table 3-1

Table 3-2.

Table 3-3.

Table 3-4.

Table 3-5.

Table 3-6.

Table 3-7.

Table 3-8.

Table 4-1.

Table 5-1.

Table 5-2.

Table 5-3.

Table 5-4.

Table 5-5.

Table 5-6.

Table 5-7.

- Table 5-8.

Table 5-9.
Physical Characteristics of Activation Products (ICRP 1983) 1-3

C-Area Releases 3-8

K-Area Releases 3-11

L-Area Releases 3-14

P-Area Releases 3-17

R-Area Releases 3-21

Atmospheric Releases of Cobalt-60 3-24

H-Area Releases 3-24

Miscellaneous Releases 3-29

Releases to Streams by Area 4-3

Site-Specific Parameters

for Atmospheric Releases 5-6

Site-Specific Parameters for Liquid Releases 5-7

Additional Site-Specific Parameters

for Liquid Releases 5-9

Atmospheric ${ }^{60}$ Cobalt Releases and Dose 5-11

Liquid ${ }^{32}$ Phosphorus Releases and Dose 5-12

Liquid ${ }^{51}$ Chromium Releases and Dose 5-13

Liquid ${ }^{60}$ Cobalt Releases and Dose 5-14

Liquid ${ }^{65}$ Zinc Releases and Dose 5-15

Maximally Exposed Individual Drinking Water

Doses at Beaufort-Jasper and Port Wentworth 5-16 


\section{Executive Summary}

A series of documents has been published in which the impact of various radionuclides released to the environment by Savannah River Site (SRS) operations has been assessed. The quantity released, the disposition of the radionuclides in the environment, and the dose to offsite individuals has been presented for carbon, cesium, iodine, plutonium, strontium, technetium, tritium, uranium, and the noble gases. An assessment of the impact of nonradioactive mercury also has been published.

This document assesses the impact of radioactive activation products released from SRS facilities since the first reactor became operational late in 1953. The isotopes reported here are those whose release resulted in the highest dose to people living near $S R S:{ }^{32} \mathrm{P},{ }^{51} \mathrm{Cr},{ }^{60} \mathrm{Co}$, and ${ }^{65} \mathrm{Zn}$.

Release pathways, emission control features, and annual releases to the aqueous and atmospheric environments are discussed. No single incident has resulted in a major acute release of activation products to the environment. The releases were the result of normal operations of the reactors and separations facilities. Releases declined over the years as better controls were established and production was reduced.

The overall radiological impact of SRS activation product atmospheric releases from 1954 through 1994 on the offsite maximally exposed individual can be characterized by a total dose of 0.76 mrem. During the same period, such an individual received a total dose of 14,400 mrem from non-SRS sources of ionizing radiation present in the environment. SRS activation product aqueous releases between 1954 and 1994 resulted in a total dose of 54 mrem to the offsite maiximally exposed individual.

The impact of SRS activation product releases on offsite populations also has been evaluated. The total collective dose was estimated as 1254 person-rem distributed among 615,000 individuals. Using international dose factors, less than one cancer death is predicted from SRS releases, while almost 100,000 fatal cancers will occur in this population from all other causes.

Activation products released from SRS present a negligible risk to the offsite population. 
This page intentionally left blank. 


\section{Chapter 1. Introduction}

Most of the radioactivity produced by the operation of a nuclear reactor results from the fission process, during which the nucleus of a fissionable atom (such as ${ }^{235} U$ ) splits into two or more nuclei, which typically are radioactive. The Radionuclide Assessment Program (RAP) has reported on fission products cesium, strontium, iodine, and technetium. Additional quantities of radioactive material are produced by activation-neutron capture by a nonradioactive nucleus. Releases of four activation products, which result in dose to the offsite population, are discussed in this publication. In descending order of dose contribution, they are ${ }^{65} \mathrm{Zn},{ }^{32} \mathrm{P},{ }^{60} \mathrm{Co}$, and ${ }^{51} \mathrm{Cr}$. Other activation products are discussed in other RAP documentsor contribute an insignificant environmental dose $1<1 \%$ of the total activation product dose. This document will discuss the production, release, migration, and dose to humans for each of these activation products. 
This page intentionally left blank. 


\section{Physical Characteristics}

Phosphorus-32 is created by capture of a neutron in $\mathrm{a}^{31} \mathrm{P}$ nucleus. It decays with a relatively short half-life of 14 days to stable ${ }^{32} \mathrm{~S}$ through the emission of an energetic beta particle. No gammas are emitted.

Chromium-51 is created by capture of a neutron in a ${ }^{50} \mathrm{Cr}$ nucleus. It decays with a half-life of 28 days to stable ${ }^{51} \mathrm{~V}$ through the capture of one of its orbital electrons. No particulate radiation is emitted but a $320 \mathrm{keV}$ gamma is emitted during $9 \%$ of the disintegrations.

Cobalt -60 is created by capturing a neutron in a ${ }^{59} \mathrm{Co}$ nucleus. It decays with a half-life of 5.3 years to stable ${ }^{60} \mathrm{Ni}$ through the emission of a low-energy beta particle. Two energetic gammas are emitted with each disintegration.
Zinc- 65 is created by capture of a neutron in a ${ }^{64} \mathrm{Zn}$ nucleus. It decays with a half-life of 244 days to ${ }^{65} \mathrm{Cu}$ through the capture of one of its orbital electrons. No particulate radiation is emitted but a $510 \mathrm{keV}$ gamma is emitted during $3.4 \%$ of the disintegrations, and a $1.12 \mathrm{MeV}$ gamma is emitted during $49 \%$ of the disintegrations.

The physical characteristics are summarized in Table 1-1.

\section{References}

ICRP, 1983, International Commission on Radiological Protection, Radionuclide Transformations, Oxford: Pergamon Press; ICRP Publication 38.

Table 1-1. Physical Characteristics of Acitivation Products (IRCP 1983)

\begin{tabular}{|c|c|c|c|c|c|}
\hline Radionuclide & $\begin{array}{c}\text { Method of } \\
\text { Production }\end{array}$ & Half-life & Decays to & $\begin{array}{c}\text { Beta Energy } \\
(\mathrm{MeV}) \text { max }\end{array}$ & $\begin{array}{c}\text { Gamma Energy } \\
(\mathrm{MeV})\end{array}$ \\
\hline \hline${ }^{32} \mathrm{p}$ & ${ }^{31} \mathrm{P}(\mathrm{n}, \gamma)$ & $14.3 \mathrm{~d}$ & ${ }^{32} \mathrm{~S}$ & 1.7 & None \\
\hline${ }^{51} \mathrm{Cr}$ & ${ }^{50} \mathrm{Cr}(\mathrm{n}, \gamma)$ & $27.7 \mathrm{~d}$ & ${ }^{51} \mathrm{~V}$ & Electron Capture & $0.32(9 \%)$ \\
\hline${ }^{60} \mathrm{Co}$ & ${ }^{59} \mathrm{Co}(\mathrm{n}, \gamma)$ & $5.27 \mathrm{y}$ & ${ }^{60} \mathrm{Ni}$ & 0.31 & $\begin{array}{c}1.17(100 \%) \\
1.33(100 \%)\end{array}$ \\
\hline${ }^{65} \mathrm{Zn}$ & ${ }^{64} \mathrm{Zn}(\mathrm{n}, \gamma)$ & $244 \mathrm{~d}$ & ${ }^{65} \mathrm{Cu}$ & Electron Capture & $\begin{array}{c}0.51(3.4 \%) \\
1.12(49 \%)\end{array}$ \\
\hline
\end{tabular}




\section{Chapter 2. Origin and Disposition of Activation Products at SRS}

This chapter presents an overview of the origin, uses, and disposition of activation products at SRS under normal operating conditions. The locations of SRS facilities that had the potential to release activation products are shown in Figure 2.1. The greatest releases of activation products occurred during the 1960s and originated primarily in the reactor facilities, which are located near the center of the 800-square-kilometer site. The history of actual releases from specific SRS facilities is presented in Chapter 3. 


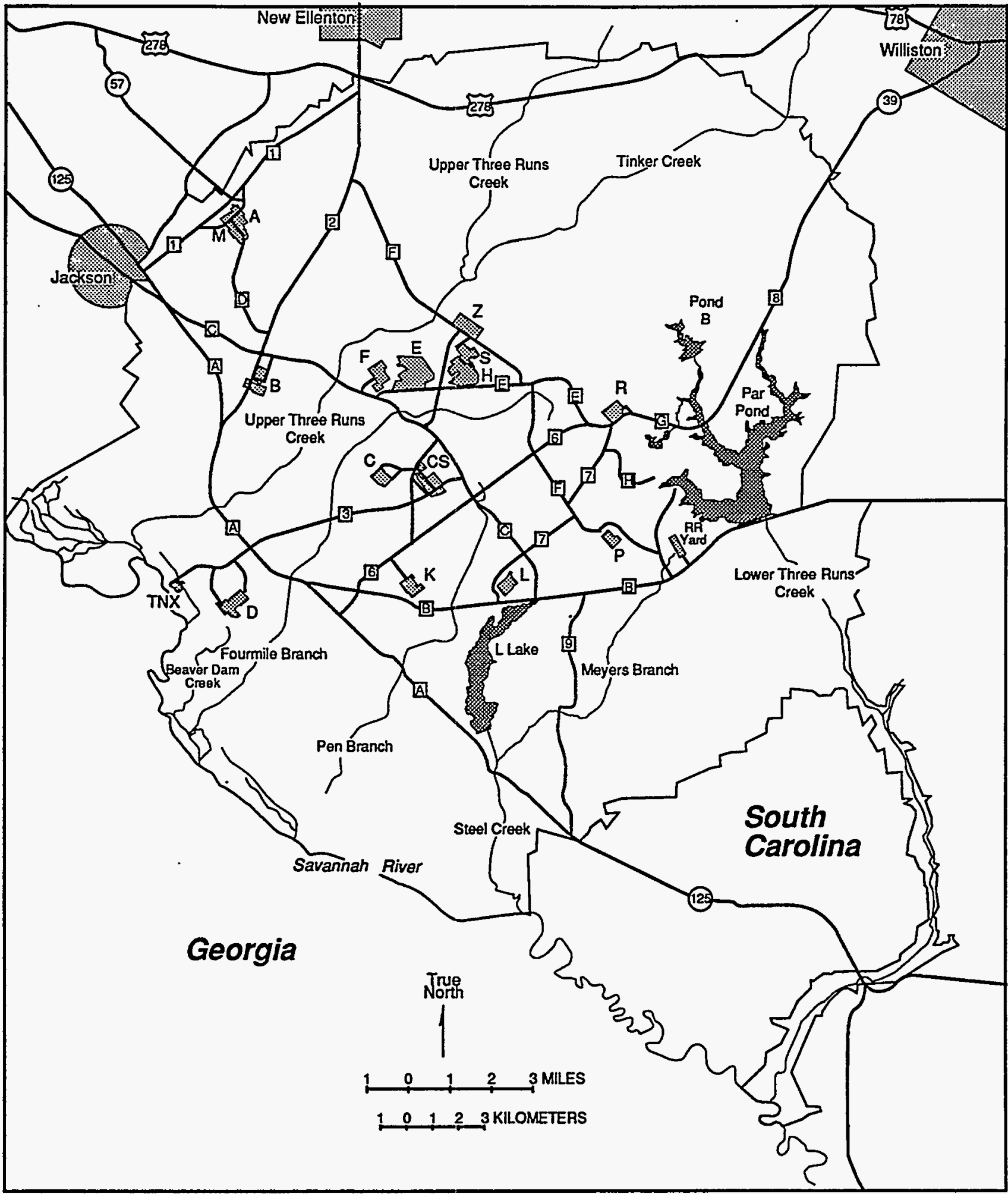

934030.03

Figure 2.1. Areas within SRS that may be Sources of Activation Product Releases 


\section{Origin of Activation Products at SRS}

Activation products at SRS originated predominantly in the reactor cores of the five production reactors. Other site operations and offsite sources contributed slightly to the inventory of activation products at SRS.

\section{Irradiation in Production Reactors}

The role of the production reactors was to produce special nuclear materials, principally tritium and plutonium, for national defense purposes. Additional radionuclides such as ${ }^{238} \mathrm{Pu}$, which is a power source for certain deep-space missions, were produced occasionally for other govemment purposes.

The reactors became operational in 1953-1955, but they did not operate continuously. The reactors alternated between periods of production and periods for maintenance or fuel and targets replacement. As of 1995, four reactors were shut down and one was on standby. The history of individual reactor operations is discussed in Chapter 3.

When a reactor was operating, neutron-induced fission reactions occurred in the ${ }^{235} \mathrm{U}$ fuel of the reactor core. Each neutron-induced fission reaction in the fuel produced several neutrons, some of which induced additional fission reactions and maintained a chain reaction. Some of the remaining neutrons interacted with target materials in the reactor. One such interaction, neutron capture in a ${ }^{238} \mathrm{U}$ target, resulted in the production of a special nuclear material, ${ }^{239} \mathrm{Pu}$. Other neutron interactions produced activation products such as ${ }^{32} \mathrm{P},{ }^{51} \mathrm{Cr},{ }^{60} \mathrm{Co}$, and ${ }^{65} \mathrm{Zn}$. Each of these will be discussed individually.

\section{Production of Phosphorus-32}

During normal reactor operations, small amounts of ${ }^{32} \mathrm{P}$ were in the moderator; these originated from $n, p$ activation of sulfur leached from moderator deionizers (Longtin 1966). In the mid 1960s, phosphoric acid, $\mathrm{H}_{3} \mathrm{PO}_{4}$, was used to clean heat exchangers, and the residual ${ }^{31} \mathrm{P}$ was converted to radioactive ${ }^{32} \mathrm{P}$ by neutron absorption (Ashley 1966).

\section{Production of Chromium-51}

Chromium-51 activity in the moderator originated from activation of stable ${ }^{50} \mathrm{Cr}$ in stainless steel reactor components in the reactor tank. Additional ${ }^{51} \mathrm{Cr}$ was produced from ${ }^{50} \mathrm{Cr}$ contained in erosion and corrosion products of stainless steel used in the reactor cooling system piping (Longtin 1972). The ${ }^{51} \mathrm{Cr}$ was formed when the erosion and corrosion products were transported into the reactor vessel and exposed to neutrons.

\section{Production of Cobalt -60}

Cobalt- 60 activity in the moderator originated in a manner similar to ${ }^{51} \mathrm{Cr}$ activity through the activation of ${ }^{59} \mathrm{Co}$ contained in erosion and corrosion products. In addition, ${ }^{60} \mathrm{Co}$ was produced for gamma radiation and heat sources (Bebbington 1990).

\section{Production of Zinc-65}

Zinc- 65 activity in the moderator originated from neutron activation of stable ${ }^{64} \mathrm{Zn}$ that was found as a trace element in aluminum reactor fuel and target components (Fox 1975).

\section{Other Sources Attributable to SRS Operations}

Small quantities of activation products were produced at SRS by test reactors and spontaneous fission, and larger quantities were produced offsite and moved to SRS. The activity levels from these sources were insignificant when compared with activity levels in the production reactors. However, the sources are discussed in the following subsections to provide a complete overview of potential activation product releases.

\section{SRS Test Reactors}

Several small nuclear reactors were in use at two SRS locations from the 1950s through the 1970s. The Heavy Water Components Test Reactor (HWCTR), located in B Area, was used in the early 1960 s to test prototype fuels for a proposed heavy water-moderated power reactor. The other test reactors, located in M Area, were used from the mid 1950s to the late 1970s. The Process Development Pile and the Lattice Test Reactor were used as zero-power mock-up facilities to test components for the production reactors. The Subcritical Experimental Pile also was used to test component designs. The Standard Pile provided neutrons for experiments such as neutron radiography and neutron activation. 


\section{Spontaneous Fission}

Spontaneous fission is a radioactive decay mode that occurs in heavy elements such as uranium and produces neutrons. Spontaneous fission is one of the mechanisms producing activation products in nature. The occurrence of spontaneous fission ranges from rare to frequent. Uranium-238 is an example of a radionuclide in which spontaneous fission rarely occurs.

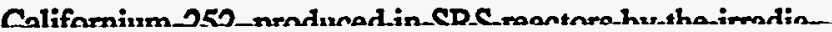

\section{Disposition of Activation Products at SRS}

The principal means for disposing of activation products are containment and time, which allows radioactive decay to occur. Table 1-1 shows the activation products produced in SRS reactors and their half-lives. Cobalt-60. with a five-

Assessment of Activation Products

in the Savannah River Site Environment (U)

WSRC-TR-95-0422

\section{Global-Fallout Activation Products}

Most global fallout occurred because of atmospheric nuclear weapons tests and the Chernobyl accident. Fallout was not distributed uniformly throughout the terrestrial environment in the vicinity of SRS. Activation product activity typically was a small fraction of the fission product activity.

\section{References}

Ashley, C., 1966, Environmental Monitoring at the Savannah River Plant, Annual Report - 1966, DPST-67-302, E. I. duPont de Nemours \& Co., Aiken, SC.
Bebbington, W. P., 1990, History of Du Pont at the Savannah River Plant, E. I. duPont de Nemours \& Co., Aiken, SC.

Fox, L. W., 1975, “Memo to J. K. Lower," SRT-ETS960031, E. I. duPont de Nemours \& Co., Aiken, SC.

Longtin, F. B., 1966, Moderator Silicate Control of ${ }^{32} P$ Release, DPSOX-6546, E. I. duPont de Nemours \& Co., Aiken, SC.

Longtin, F. B., 1972, 100-Area Release Guides for ${ }^{95} \mathrm{Zr}$ $\mathrm{Nb}$ and ${ }^{51} \mathrm{Cr}$, SRT-ETS-960029, E. I. duPont de Nemours \& Co., Aiken, SC. 


\section{Chapter 3. Releases and Stored Inventories of Activation Products at SRS}

Routine operations at SRS facilities have released activation products to the regional environment surrounding the Site. The most significant releases occurred during the 1960s when activation products were released to seepage basins and site streams. The largest releases originated in the reactor facilities located near the center of the 800-square-kilometer site. The proximity of these facilities to major streams within the SRS boundary is shown in Figure 3.1, which also shows the location of other facilities having the potential to release activation products.

This chapter discusses activation products at SRS facilities in terms of possible release pathways, emission control features, and annual releases to the aqueous and atmospheric environments. 


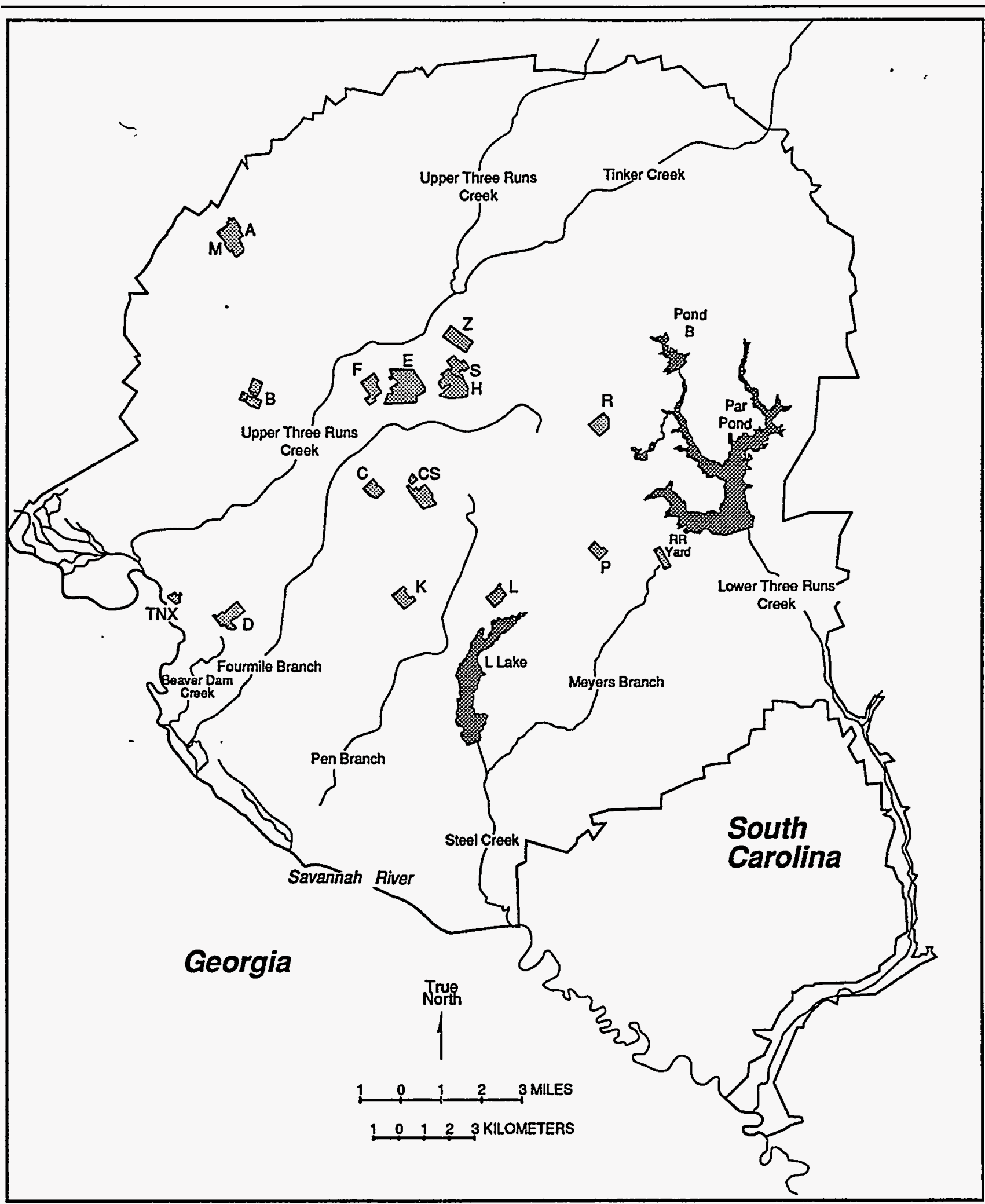

M934030.04

Figure 3.1. Proximity of SRS Facilities to Site Streams 


\section{Reactor Facilities}

The five production reactors at SRS were identified by the letter designations $C, K, L, P$, and $R$. The reactors were designed to irradiate various targets to produce special nuclear materials (principally, tritium and plutonium) for national defense purposes. Specific radionuclides for other government purposes also were produced including ${ }^{238} \mathrm{Pu}$, a power source for certain deep-space missions.

\section{Facility Operations}

When a nuclear reactor was operating, nuclear fission reactions occurred in the reactor core. The principal components of the core were the fuel, targets, control rods, and moderator. Control rods were neutron-absorbing materials positioned in the core to control the power level of a reactor.

The moderator in SRS reactors was heavy water that was circulated around the fuel and target elements in the reactor core. The moderator decreased the kinetic energy (slowed the speed) of neutrons emitted in the fission process. Slow neutrons are more likely than fast neutrons to interact with fuel and target materials.

The moderator also functioned as the primary coolant to remove heat from fuel and target elements. Heat then was transferred from the moderator to the secondary coolant by heat exchangers. The SRS reactors used either river or pond water as the secondary coolant in the heat exchangers.

In reactors that used water from the Savannah River as the secondary coolant, the river water was passed through the shell side of the heat exchanger and discharged to a site stream that flowed back to the Savannah River. When the $L$ Reactor was upgraded and restarted in the 1980s, a cooling lake (L Lake) was constructed to mitigate the thermal impact on Steel Creek. River water was pumped through the $L$ Area heat exchangers and discharged into L Lake without recirculation. L Lake overflowed into Steel Creek. Reactors that used pond water as the secondary coolant discharged the water from the heat exchanger to a canal that flowed to a series of cooling ponds. Cooled pond water was recirculated through the heat exchanger.

Under normal operating conditions, fuel and target elements were irradiated for a specified time, removed from the reactor core, and stored underwater in the VTS basin of the reactor building. Storage in the VTS basin for the cooling period allowed short-lived radionuclides to decay to low levels before reprocessing of the fuel and targets began. After cooling, the elements were moved to the disassembly basin and prepared for transfer to the chemical separations areas.

\section{Pathways for Release}

During normal reactor operations, trace quantities of corrosion and erosion impurities (see Chapter 2) were dispersed in the moderator, and activation products were created by neutron capture. Most of these impurities were removed from the moderator by an on-line ion exchange purification process.

Once activation products were in the moderator, they circulated with the moderator and adsorbed onto fuel and target surfaces. When a leak developed in a heat exchanger tube, some activation products were released along with primary coolant into the secondary coolant-and subsequently to the environment. Any activation products released by this pathway were not quantified; however, the secondary coolant was monitored for beta-gamma activity. Leakage to the secondary coolant was a minor pathway compared to release from the tube storage basins. Low operating temperatures of the reactors (below the boiling temperature of heavy water), coupled with high-boiling points for activation product compounds, minimized volatilization of activation products into the blanket gas so that airborne releases were minimal.

Similar pathways occurred during cooling of irradiated materials in the VTS basin and during subsequent handling of those materials in the disassembly basin. Water also leached adsorbed activation products from the exterior surfaces of fuel and targets. Once in the basin water, the activation products circulated with the water, became trapped in the deionizer, and adsorbed onto fuel and target surfaces. Again, low temperatures and activation product solubility minimized the airbome release of activation products from the VTS.

Continuous purges of the VTS basin water were the primary pathways by which aqueous activation products were released to the environment. The VTS basin waters initially were purged directly to site streams to remove the heat generated by the stored irradiated fuel and targets and to maintain clarity in the storage basins. After installing basin heat exchangers, deion- 
Figure 3.2. C-Area P-32 Releases to Streams and Basins

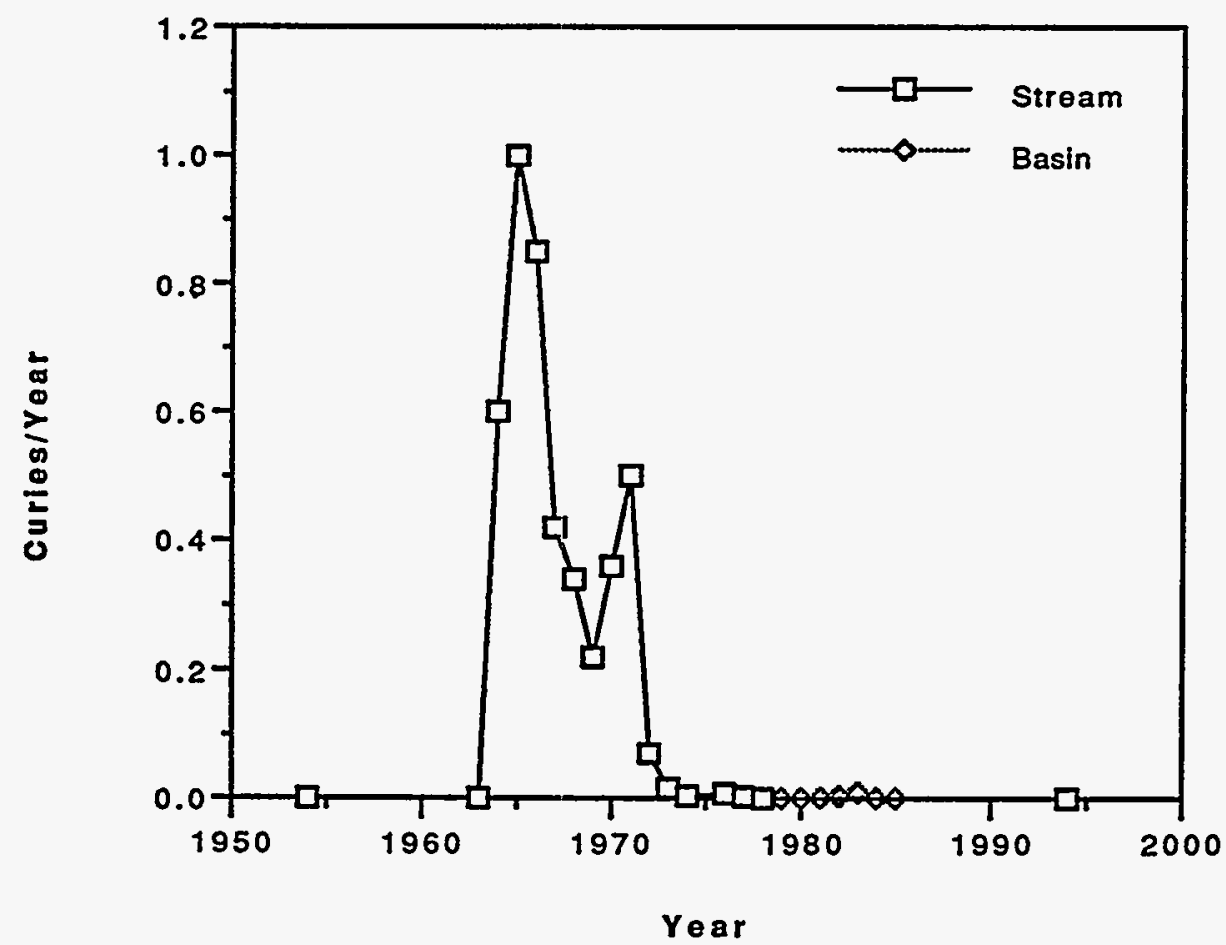

Figure.3.3. C-Area Cr-51 Releases to Streams and Basins

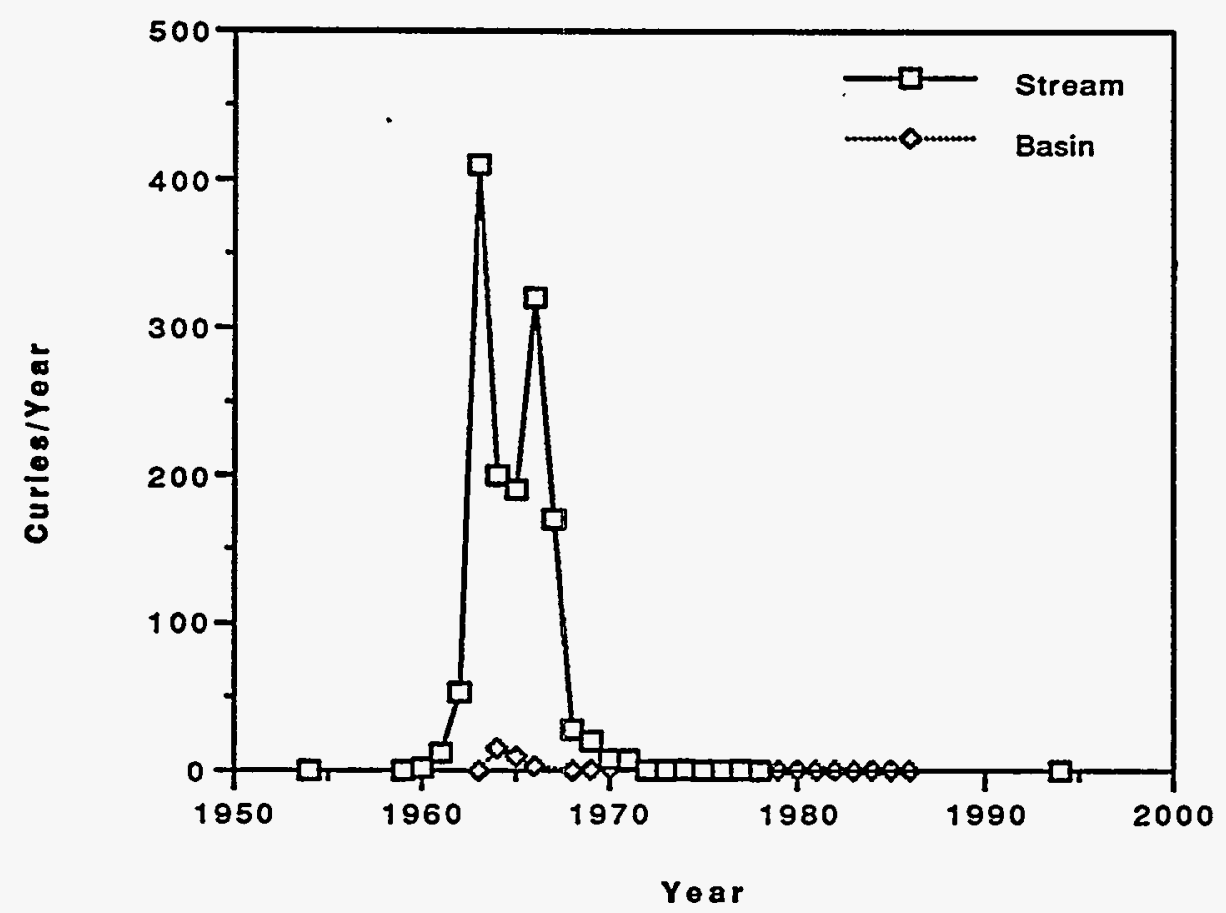


Figure 3.4. C-Area Co-60 Releases to Streams and Basins

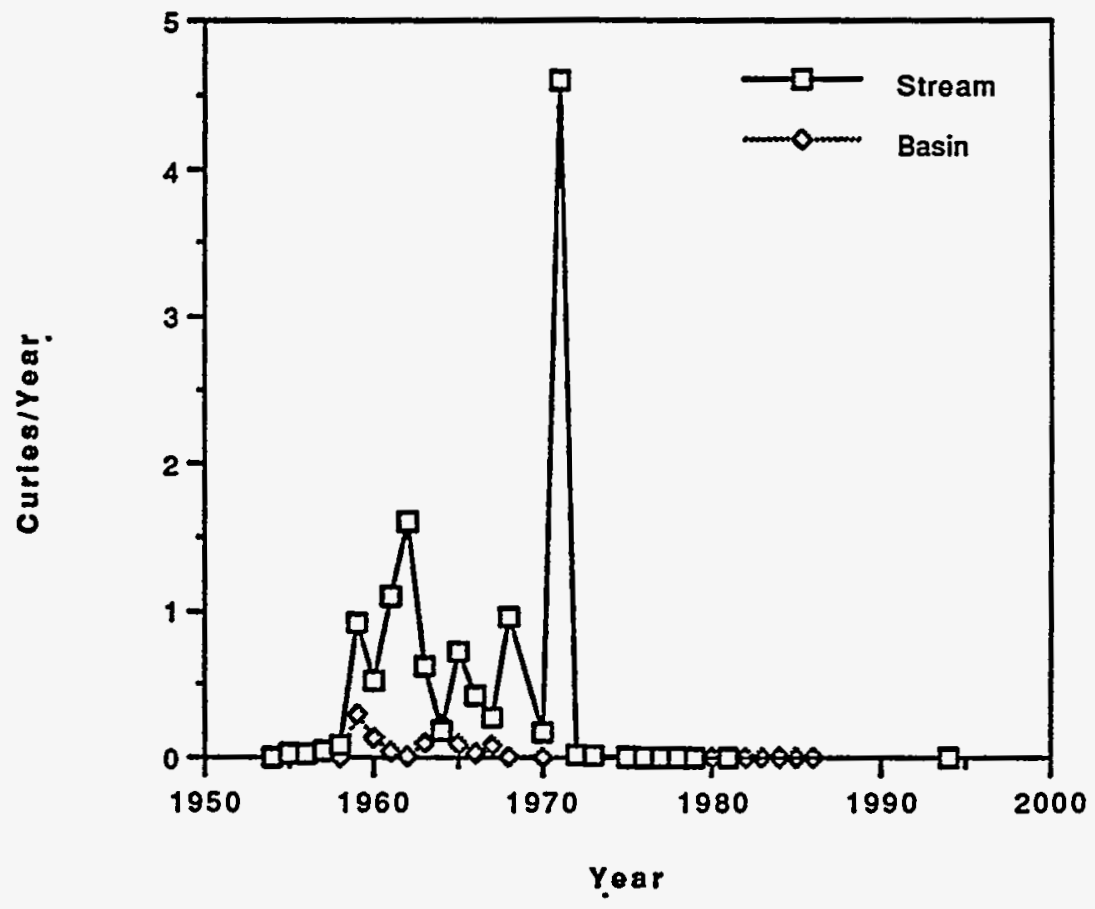

Figure 3.5. C-Area Zn-65 Releases to Streams and Basins

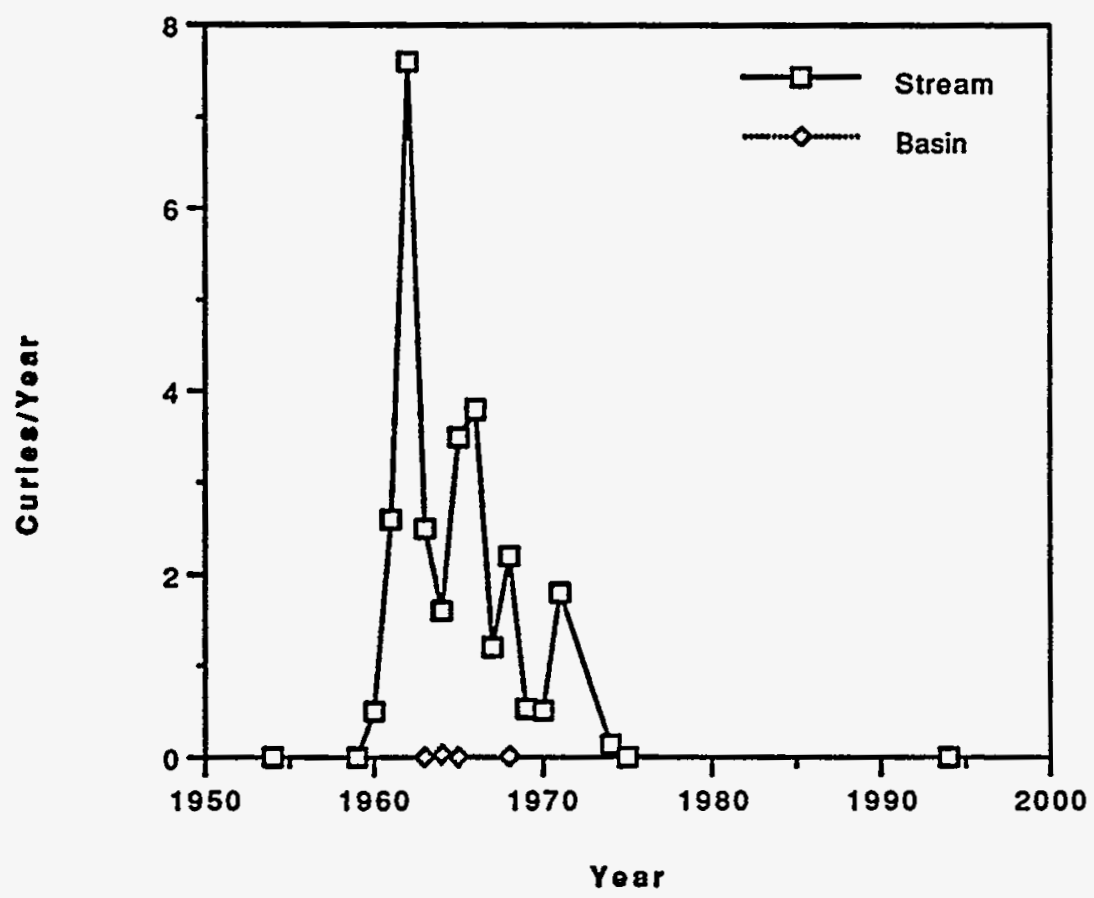


Assessment of Activation Products

in the Savannah River Site Environment (U)

Table 3-1. C-Area Releases

Releases to Streams (Ci)

Releases to Basins (Ci)

\begin{tabular}{|c|c|c|c|c|c|c|c|c|}
\hline Year & P-32 & $\mathrm{Cr}_{\mathrm{r}-51}$ & $\mathrm{C}_{0}-60$ & $\mathrm{Zn}-65$ & P-32 & Cr-51 & $\mathrm{C} 0-60$ & $\mathrm{Zn}-65$ \\
\hline 1954 & & & & & & & & \\
\hline 1955 & & & $2.6 \times 10^{-2}$ & & & & & \\
\hline 1956 & & & $2.4 \times 10^{-2}$ & & & & & \\
\hline 1957 & & & $4.4 \times 10^{-2}$ & & & & & \\
\hline 1958 & & & $8.2 \times 10^{-2}$ & & & & & \\
\hline 1959 & & & $9.2 \times 10^{-1}$ & & & & $2.9 \times 10^{-1}$ & \\
\hline 1960 & & $1.7 \times 10^{0}$ & $5.2 \times 10^{-1}$ & $5.0 \times 10^{-1}$ & & & $1.3 \times 10^{-1}$ & \\
\hline 1961 & & $1.2 \times 10^{1}$ & $1.1 \times 10^{0}$ & $2.6 \times 10^{0}$ & & & $4.0 \times 10^{-2}$ & \\
\hline 1962 & & $5.3 \times 10^{1}$ & $1.6 \times 10^{0}$ & $7.6 \times 10^{0}$ & & & $7.8 \times 10^{-3}$ & \\
\hline 1963 & & $4.1 \times 10^{2}$ & $6.2 \times 10^{-1}$ & $2.5 \times 10^{0}$ & & & $9.8 \times 10^{-2}$ & \\
\hline 1964 & $6.0 \times 10^{-1}$ & $2.0 \times 10^{2}$ & $1.8 \times 10^{-1}$ & $1.6 \times 10^{0}$ & & $1.5 \times 10^{1}$ & $2.3 \times 10^{-1}$ & $3.0 \times 10^{-2}$ \\
\hline 1965 & $1.0 \times 10^{0}$ & $1.9 \times 10^{2}$ & $7.2 \times 10^{-1}$ & $3.5 \times 10^{0}$ & & $9.2 \times 10^{0}$ & $9.0 \times 10^{-2}$ & $4.0 \times 10^{-3}$ \\
\hline 1966 & $8.5 \times 10^{-1}$ & $3.2 \times 10^{2}$ & $4.2 \times 10^{-1}$ & $3.8 \times 10^{0}$ & & $3.0 \times 10^{0}$ & $3.0 \times 10^{-2}$ & \\
\hline 1967 & $4.2 \times 10^{-1}$ & $1.7 \times 10^{2}$ & $2.7 \times 10^{-1}$ & $1.2 \times 10^{0}$ & & & $8.0 \times 10^{-2}$ & \\
\hline 1968 & $3.4 \times 10^{-1}$ & $2.8 \times 10^{l}$ & $9.6 \times 10^{-1}$ & $2.2 \times 10^{0}$ & & $2.0 \times 10^{-1}$ & $4.0 \times 10^{-3}$ & $1.0 \times 10^{-2}$ \\
\hline 1969 & $2.2 \times 10^{-1}$ & $2.0 \times 10^{1}$ & & $5.3 \times 10^{-1}$ & & $4.2 \times 10^{-1}$ & & \\
\hline 1970 & $3.6 \times 10^{-1}$ & $7.7 \times 10^{0}$ & $1.7 \times 10^{-1}$ & $5.1 \times 10^{1}$ & & $1.6 \times 10^{0}$ & $1.0 \times 10^{-3}$ & \\
\hline 1971 & $5.0 \times 10^{-1}$ & $7.2 \times 10^{0}$ & $4.6 \times 10^{0}$ & $1.8 \times 10^{0}$ & & & & \\
\hline 1972 & $7.0 \times 10^{-2}$ & $1.8 \times 10^{1}$ & $2.0 \times 10^{-2}$ & & & & & \\
\hline 1973 & $1.6 \times 10^{-2}$ & $1.6 \times 10^{1}$ & $1.4 \times 10^{-2}$ & & & & & \\
\hline 1974 & $4.0 \times 10^{-3}$ & $4.9 \times 10^{1}$ & & $1.4 \times 10^{-1}$ & & & & \\
\hline 1975 & & $6.8 \times 10^{2}$ & $4.0 \times 10^{-3}$ & $2.0 \times 10^{-3}$ & & & & \\
\hline 1976 & $8.0 \times 10^{-3}$ & $1.8 \times 10^{1}$ & $1.0 \times 10^{-3}$ & & & & & \\
\hline 1977 & $3.2 \times 10^{-3}$ & $4.3 \times 10^{-1}$ & $8.0 \times 10^{-4}$ & & & & & \\
\hline 1978 & $2.7 \times 10^{-5}$ & $2.5 \times 10^{-2}$ & $3.9 \times 10^{-4}$ & & $4.7 \times 10^{-5}$ & $1.9 \times 10^{-2}$ & & \\
\hline 1979 & & & $3.5 \times 10^{-5}$ & & $4.0 \times 10^{-4}$ & $1.7 \times 10^{-1}$ & $1.4 \times 10^{-4}$ & \\
\hline 1980 & & & & & $3.6 \times 10^{-4}$ & $1.3 \times 10^{-1}$ & $2.0 \times 10^{-4}$ & \\
\hline 1981 & & & $1.3 \times 10^{-4}$ & & $1.4 \times 10^{-3}$ & $1.8 \times 10^{-1}$ & $2.1 \times 10^{-4}$ & \\
\hline 1982 & & & & & $3.0 \times 10^{-3}$ & $2.8 \times 10^{-1}$ & $6.0 \times 10^{-5}$ & \\
\hline 1983 & & & & & $1.0 \times 10^{-2}$ & $3.5 \times 10^{-4}$ & $1.8 \times 10^{-4}$ & \\
\hline 1984 & & & & & $2.3 \times 10^{-4}$ & $2.4 \times 10^{-2}$ & $8.5 \times 10^{-4}$ & \\
\hline 1985 & & & & & $2.0 \times 10^{-6}$ & $1.5 \times 10^{-1}$ & $2.4 \times 10^{-4}$ & \\
\hline 1986 & & & & & & $6.5 \times 10^{-4}$ & $1.2 \times 10^{-4}$ & \\
\hline 1987 & & & & & & & & \\
\hline 1988 & & & & & & & & \\
\hline 1989 & & & & & & & & \\
\hline 1990 & & & & & & & & \\
\hline 1991 & & & & & & & & \\
\hline 1992 & & & & & & & & \\
\hline 1993 & & & & & & & & \\
\hline 1994 & & & & & & & & \\
\hline Total & $4.4 \times 10^{0}$ & $1.4 \times 10^{3}$ & $1.2 \times 10^{1}$ & $2.8 \times 10^{1}$ & $1.5 \times 10^{-2}$ & $3.0 \times 10^{1}$ & $1.0 \times 10^{0}$ & $4.4 \times 10^{-2}$ \\
\hline
\end{tabular}


Figure 3.6. K-Area P-32 Releases to Streams and Basins

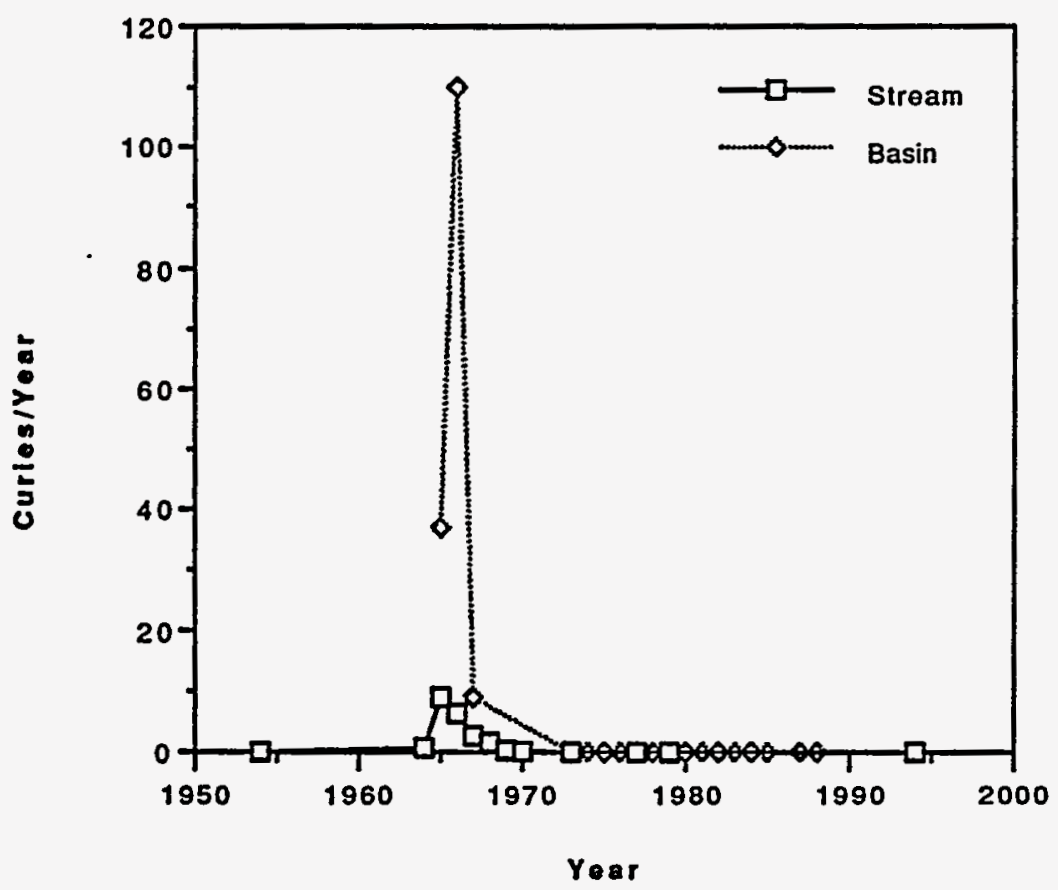

Figure 3.7. K-Area Cr-51 Releases to Streams and Basins

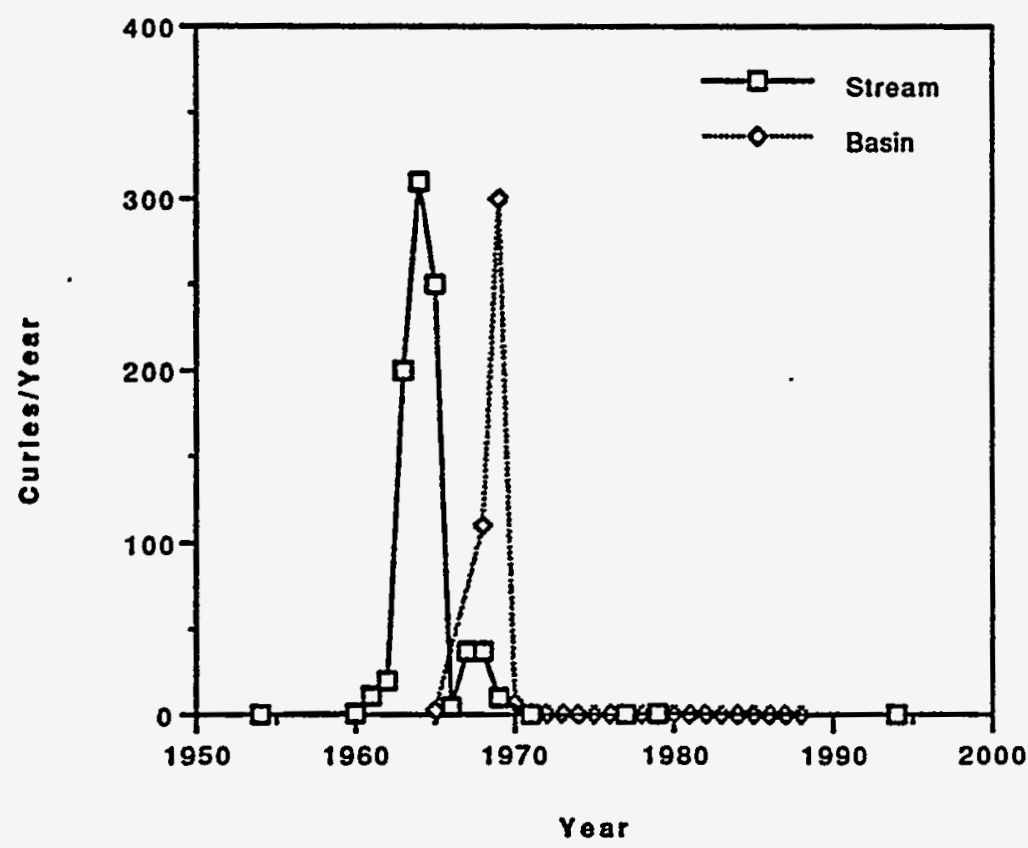


Figure 3.8. K-Area Co-60 Releases to Streams and Basins

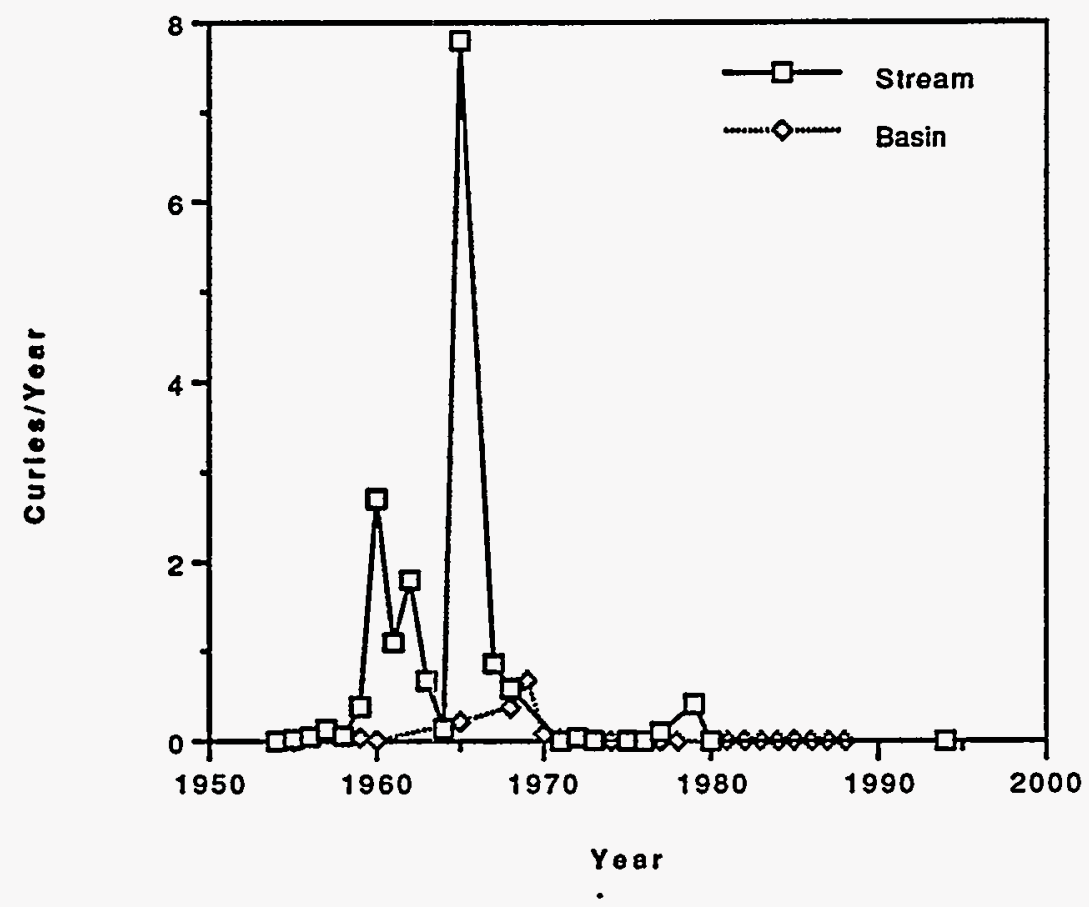

Figure 3.9. K-Area Żn-65 Releases to Streams and Basins

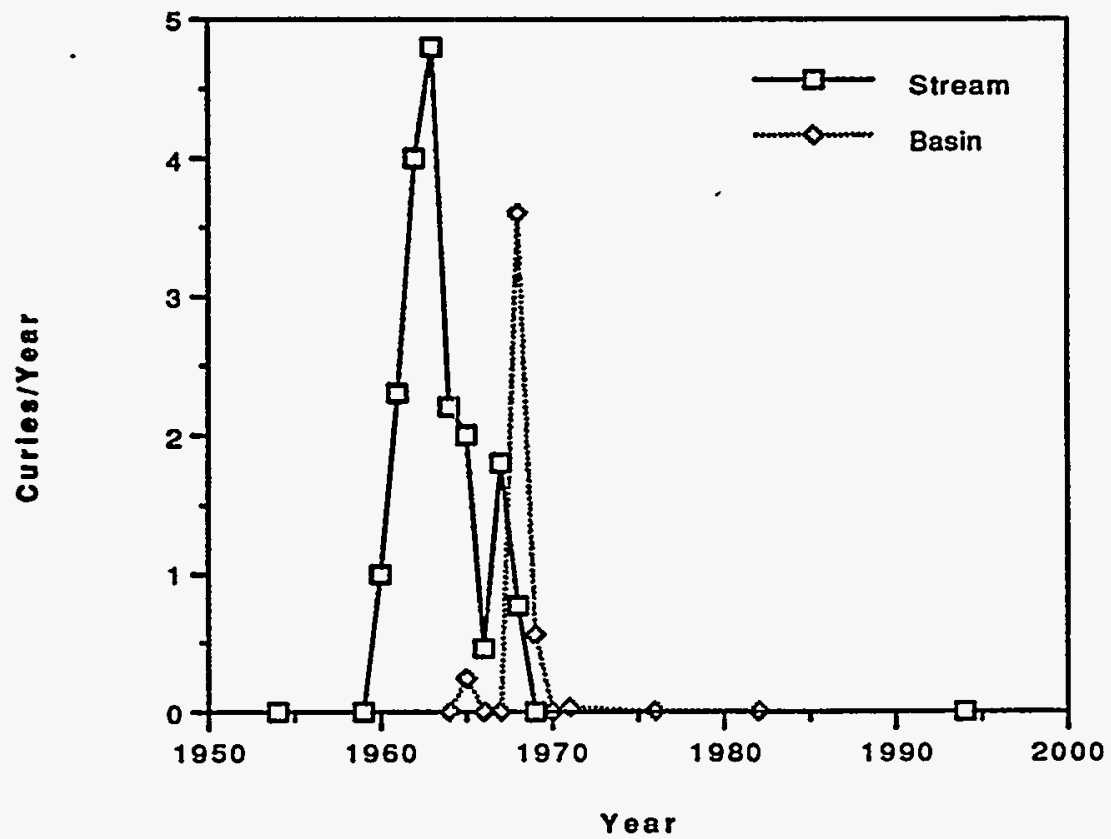


Table 3-2. K-Area Releases

Releases to Streams (Ci)

Releases to Basins (Ci)

\begin{tabular}{|c|c|c|c|c|c|c|c|c|}
\hline Year & P-32 & Cr-51 & $\mathrm{Co}-60$ & $\mathrm{Zn}-65$ & P-32 & $\mathrm{Cr}_{\mathrm{r}-51}$ & $\mathrm{CO}-60$ & $\mathrm{Zn}-65$ \\
\hline 1954 & & & & & & & & \\
\hline 1955 & & & $2.2 \times 10^{-2}$ & & & & & \\
\hline 1956 & & & $4.8 \times 10^{-2}$ & & & & & \\
\hline 1957 & & & $1.3 \times 10^{-1}$ & & & & & \\
\hline 1958 & & & $6.2 \times 10^{-2}$ & & & & & \\
\hline 1959 & & & $3.8 \times 10^{-1}$ & & & & $4.0 \times 10^{-2}$ & \\
\hline 1960 & & $8.4 \times 10^{-1}$ & $2.7 \times 10^{0}$ & $1.0 \times 10^{0}$ & & & $6.2 \times 10^{-3}$ & \\
\hline 1961 & & $1.1 \times 10^{1}$ & $1.1 \times 10^{0}$ & $2.3 \times 10^{0}$ & & & & \\
\hline 1962 & & $2.0 \times 10^{1}$ & $1.8 \times 10^{0}$ & $4.0 \times 10^{0}$ & & & & \\
\hline 1963 & & $2.0 \times 10^{2}$ & $6.7 \times 10^{-1}$ & $4.8 \times 10^{0}$ & & & & \\
\hline 1964 & $6.5 \times 10^{-1}$ & $3.1 \times 10^{2}$ & $1.4 \times 10^{-1}$ & $2.2 \times 10^{0}$ & & & & \\
\hline 1965 & $9.0 \times 10^{0}$ & $2.5 \times 10^{2}$ & $7.8 \times 10^{0}$ & $2.0 \times 10^{0}$ & $3.7 \times 10^{1}$ & $2.4 \times 10^{0}$ & $2.2 \times 10^{-1}$ & $2.4 \times 10^{-1}$ \\
\hline 1966 & $6.4 \times 10^{0}$ & $4.7 \times 10^{0}$ & & $4.6 \times 10^{-1}$ & $1.1 \times 10^{2}$ & & & \\
\hline 1967 & $2.7 \times 10^{0}$ & $3.7 \times 10^{1}$ & $8.6 \times 10^{-1}$ & $1.8 \times 10^{0}$ & $9.0 \times 10^{0}$ & & & \\
\hline 1968 & $1.6 \times 10^{0}$ & $3.7 \times 10^{1}$ & $5.8 \times 10^{-1}$ & $7.7 \times 10^{-1}$ & & $1.1 \times 10^{2}$ & $3.7 \times 10^{-1}$ & $3.6 \times 10^{0}$ \\
\hline 1969 & $3.0 \times 10^{-1}$ & $1.0 \times 10^{1}$ & & & & $3.0 \times 10^{2}$ & $6.7 \times 10^{-1}$ & $5.6 \times 10^{-1}$ \\
\hline 1970 & $1.3 \times 10^{-1}$ & & & & & $6.9 \times 10^{0}$ & $8.0 \times 10^{-2}$ & \\
\hline 1971 & & $1.2 \times 10^{-3}$ & $2.2 \times 10^{-3}$ & & & $6.3 \times 10^{-1}$ & $3.0 \times 10^{-2}$ & $3.0 \times 10^{-2}$ \\
\hline 1972 & & & $4.0 \times 10^{-2}$ & & & $5.1 \times 10^{-1}$ & & \\
\hline 1973 & $4.6 \times 10^{-2}$ & & $8.0 \times 10^{-3}$ & & $1.8 \times 10^{-2}$ & $4.1 \times 10^{-1}$ & $3.0 \times 10^{-3}$ & \\
\hline 1974 & $\because$ & & & & $2.2 \times 10^{-2}$ & $1.6 \times 10^{-1}$ & $1.0 \times 10^{-3}$ & \\
\hline 1975 & & & $4.0 \times 10^{-3}$ & & $8.0 \times 10^{-3}$ & $5.8 \times 10^{-2}$ & $1.0 \times 10^{-3}$ & \\
\hline 1976 & & & $1.0 \times 10^{-3}$ & & $9.0 \times 10^{-3}$ & $3.5 \times 10^{-1}$ & $1.0 \times 10^{-3}$ & $2.0 \times 10^{-3}$ \\
\hline 1977 & $5.0 \times 10^{-4}$ & $1.6 \times 10^{-1}$ & $1.0 \times 10^{-1}$ & & $2.2 \times 10^{-2}$ & $1.4 \times 10^{-1}$ & $2.6 \times 10^{-5}$ & \\
\hline 1978 & & & & & $8.5 \times 10^{-4}$ & $9.3 \times 10^{-2}$ & $1.2 \times 10^{-4}$ & \\
\hline 1979 & $4.0 \times 10^{-3}$ & $5.4 \times 10^{-1}$ & $4.1 \times 10^{-1}$ & & $1.3 \times 10^{-4}$ & $1.5 \times 10^{-1}$ & & \\
\hline 1980 & & & $1.5 \times 10^{-3}$ & & $5.6 \times 10^{-4}$ & $2.2 \times 10^{-1}$ & $1.7 \times 10^{-3}$ & \\
\hline 1981 & & & & & $6.7 \times 10^{-4}$ & $8.2 \times 10^{-2}$ & $1.9 \times 10^{-3}$ & \\
\hline 1982 & & & & & $3.4 \times 10^{-3}$ & $3.6 \times 10^{-1}$ & $6.6 \times 10^{-3}$ & $5.5 \times 10^{-4}$ \\
\hline 1983 & & & & & $4.3 \times 10^{-3}$ & $1.2 \times 10^{-2}$ & $2.8 \times 10^{-3}$ & \\
\hline 1984 & & & & & $2.7 \times 10^{-3}$ & $2.1 \times 10^{-2}$ & $3.4 \times 10^{-4}$ & \\
\hline 1985 & & & & & $1.1 \times 10^{-4}$ & $2.4 \times 10^{-2}$ & $1.0 \times 10^{-2}$ & \\
\hline 1986 & & & & & & $1.4 \times 10^{-2}$ & $3.2 \times 10^{-3}$ & \\
\hline 1987 & & & & & $1.0 \times 10^{-6}$ & $5.8 \times 10^{-3}$ & $1.2 \times 10^{-3}$ & \\
\hline 1988 & & & & & $7.4 \times 10^{-7}$ & $7.2 \times 10^{-4}$ & $2.1 \times 10^{-4}$ & \\
\hline 1989 & & & & & & & & \\
\hline 1990 & & & & & & & & \\
\hline 1991 & & & & & & & & \\
\hline 1992 & & & & & & & & \\
\hline 1993 & & & & & & & & \\
\hline 1994 & & & & & & & & \\
\hline Total & $2.1 \times 10^{1}$ & $8.8 \times 10^{2}$ & $1.7 \times 10^{1}$ & $1.9 \times 10^{1}$ & $1.6 \times 10^{2}$ & $4.2 \times 10^{2}$ & $1.5 \times 10^{0}$ & $4.4 \times 10^{0}$ \\
\hline
\end{tabular}


Figure 3.10. L-Area P-32 Releases to Streams and Basins

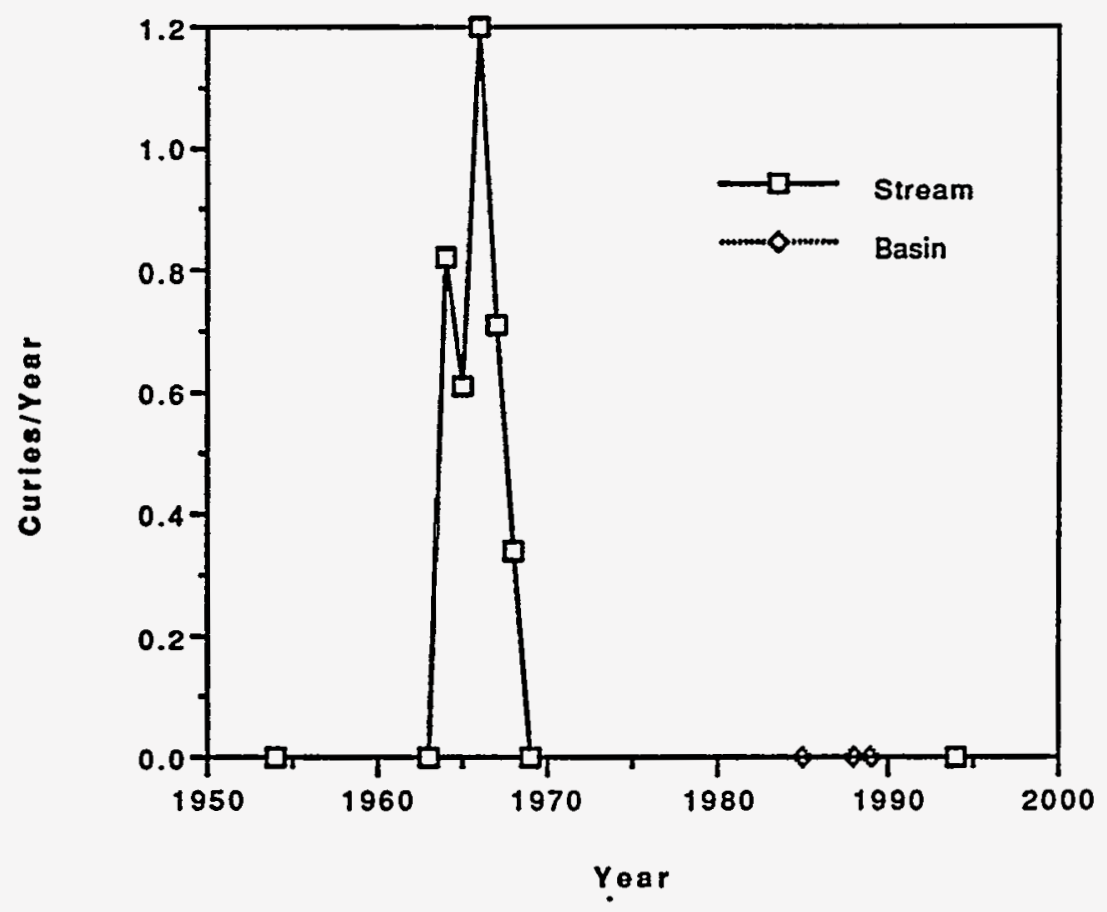

Figure 3.11. L-Area Cr-51 Releases to Streams and Basins

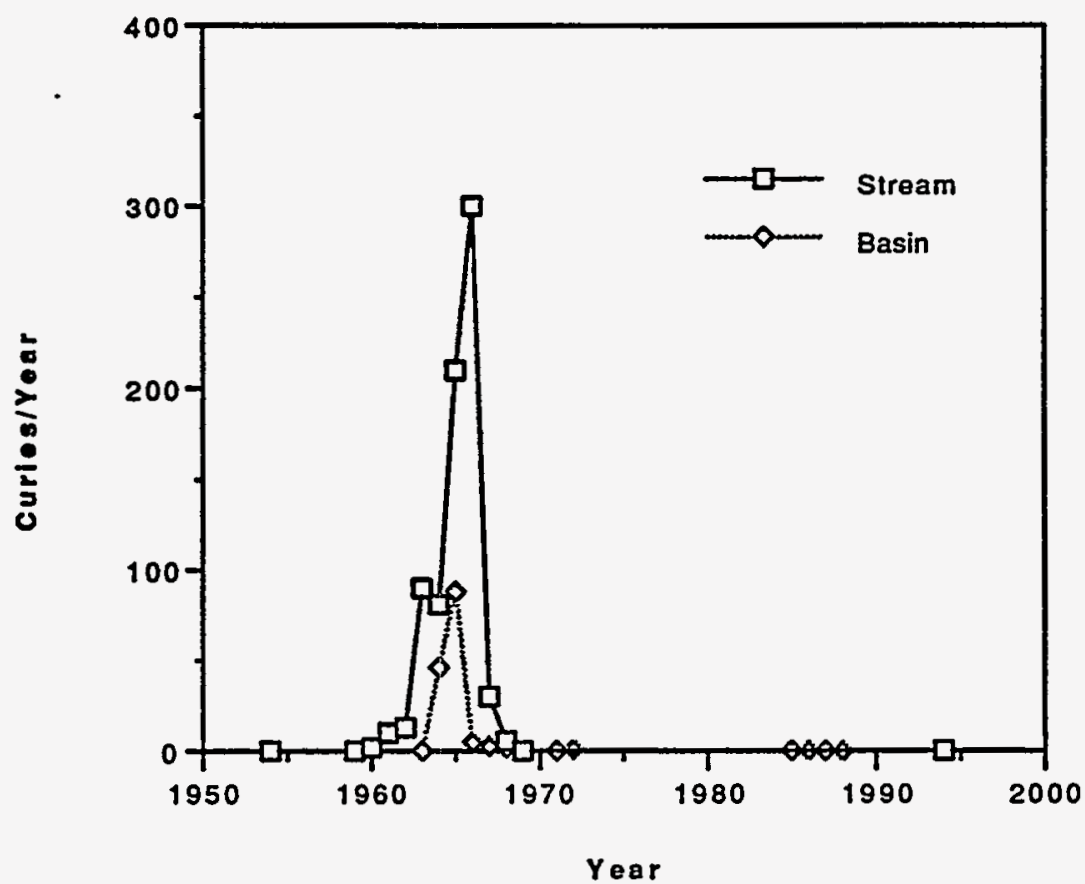


Figure 3.12. L-Area C0-60 Releases to Streams and Basins

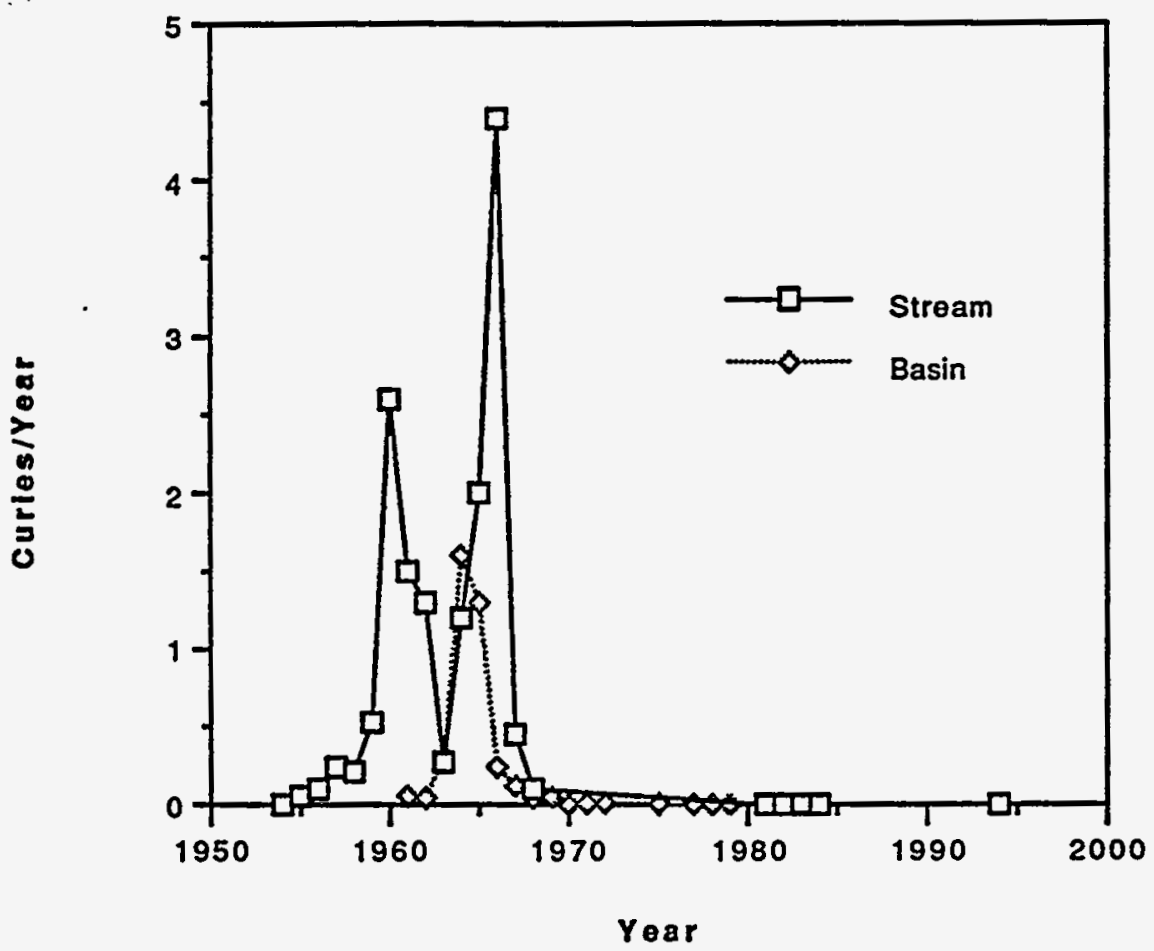

Figure 3.13. L-Area Zn-65 Releases to Streams and Basins

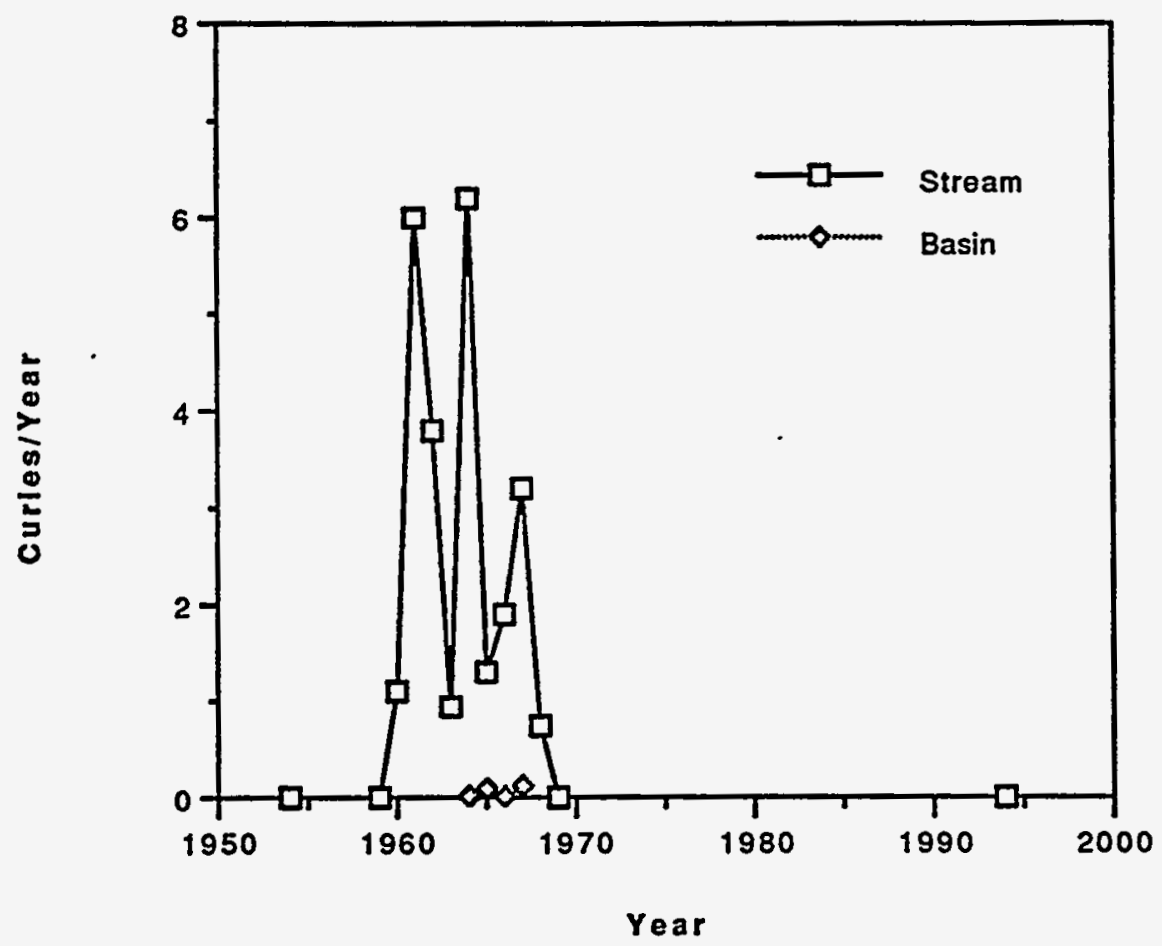


Table 3-3. L-Area Releases

Releases to Streams (Ci)

Releases to Basins (Cl)

\begin{tabular}{|c|c|c|c|c|c|c|c|c|}
\hline Year & P-32 & Cr-51 & Co-60 & $\mathrm{Zn}-65$ & P-32 & $\mathrm{C}_{\mathrm{T}-51}$ & $\mathrm{C} 0-60$ & $\mathrm{Zn} \cdot 65$ \\
\hline 1954 & & & & & & & & \\
\hline 1955 & & & $5.6 \times 10^{-2}$ & & & & & \\
\hline 1956 & & & $1.0 \times 10^{-1}$ & & & & & \\
\hline 1957 & & & $2.4 \times 10^{-1}$ & & & & & \\
\hline 1958 & & & $2.1 \times 10^{-1}$ & & & & & \\
\hline 1959 & & & $5.3 \times 10^{-1}$ & & & & & \\
\hline 1960 & & $1.9 \times 10^{0}$ & $2.6 \times 10^{0}$ & $1.1 \times 10^{0}$ & & & & • \\
\hline 1961 & & $1.0 \times 10^{1}$ & $1.5 \times 10^{0}$ & $6.0 \times 10^{0}$ & & & $5.3 \times 10^{-2}$ & \\
\hline 1962 & & $1.3 \times 10^{1}$ & $1.3 \times 10^{0}$ & $3.8 \times 10^{0}$ & & & $4.2 \times 10^{-2}$ & \\
\hline 1963 & & $9.0 \times 10^{1}$ & $2.7 \times 10^{-1}$ & $9.4 \times 10^{-1}$ & & & $3.1 \times 10^{-1}$ & \\
\hline 1964 & $8.2 \times 10^{-1}$ & $8.1 \times 10^{1}$ & $1.2 \times 10^{0}$ & $6.2 \times 10^{0}$ & & $4.6 \times 10^{1}$ & $1.6 \times 10^{0}$ & $1.0 \times 10^{-2}$ \\
\hline 1965 & $6.1 \times 10^{-1}$ & $2.1 \times 10^{2}$ & $2.0 \times 10^{0}$ & $1.3 \times 10^{0}$ & & $8.8 \times 10^{1}$ & $1.3 \times 10^{0}$ & $9.0 \times 10^{-2}$ \\
\hline 1966 & $1.2 \times 10^{0}$ & $3.0 \times 10^{2}$ & $4.4 \times 10^{0}$ & $1.9 \times 10^{0}$ & & $4.7 \times 10^{0}$ & $2.4 \times 10^{-1}$ & $1.0 \times 10^{-2}$ \\
\hline 1967 & $7.1 \times 10^{-1}$ & $3.0 \times 10^{1}$ & $4.5 \times 10^{-1}$ & $3.2 \times 10^{0}$ & & $2.5 \times 10^{0}$ & $1.2 \times 10^{-1}$ & $1.2 \times 10^{-1}$ \\
\hline 1968 & $3.4 \times 10^{-1}$ & $5.6 \times 10^{0}$ & $1.0 \times 10^{-1}$ & $7.4 \times 10^{-1}$ & & $2.0 \times 10^{0}$ & $4.0 \times 10^{-2}$ & \\
\hline 1969 & & & & & & $1.0 \times 10^{-3}$ & $4.9 \times 10^{-2}$ & \\
\hline 1970 & & & & & & & $2.0 \times 10^{-3}$ & \\
\hline 1971 & & & & & & $2.3 \times 10^{-2}$ & $1.0 \times 10^{-2}$ & \\
\hline 1972 & & & & & & $6.5 \times 10^{-1}$ & $1.0 \times 10^{-2}$ & \\
\hline 1973 & & & & & & & & \\
\hline 1974 & & & & & & & & \\
\hline 1975 & & & & & & & $7.0 \times 10^{-3}$ & \\
\hline 1976 & & & & & $\cdot$ & & & \\
\hline 1977 & & & & & & & $2.1 \times 10^{-4}$ & \\
\hline 1978 & & & & & & & $3.4 \times 10^{-4}$ & \\
\hline 1979 & & & & & & & $1.8 \times 10^{-4}$ & \\
\hline 1980 & & & & & & & & \\
\hline 1981 & & & $1.1 \times 10^{-4}$ & & & & & \\
\hline 1982 & & & $1.1 \times 10^{-4}$ & & & & & \\
\hline 1983 & & & $1.9 \times 10^{-3}$ & & & & & \\
\hline 1984 & & & $3.1 \times 10^{-4}$ & & & & & \\
\hline 1985 & & & & & $8.0 \times 10^{-6}$ & $1.8 \times 10^{-4}$ & & \\
\hline 1986 & & & & & & $6.1 \times 10^{-3}$ & & \\
\hline 1987 & & & & & & $3.8 \times 10^{-3}$ & & \\
\hline 1988 & & & & & $9.8 \times 10^{-6}$ & $1.2 \times 10^{-3}$ & & \\
\hline 1989 & & & & & $1.8 \times 10^{-5}$ & & & \\
\hline 1990 & & & & & & & & \\
\hline 1991 & & & & & & & & \\
\hline 1992 & & & & & & & & \\
\hline 1993 & & & & & & & & \\
\hline 1994 & & & & & & & & \\
\hline Total & $3.7 \times 10^{0}$ & $7.4 \times 10^{2}$ & $1.5 \times 10^{1}$ & $2.5 \times 10^{1}$ & $3.6 \times 10^{-5}$ & $1.4 \times 10^{2}$ & $3.8 \times 10^{0}$ & $2.3 \times 10^{-1}$ \\
\hline
\end{tabular}


Figure 3.14. P-Area P-32 Releases to Streams and Basins:

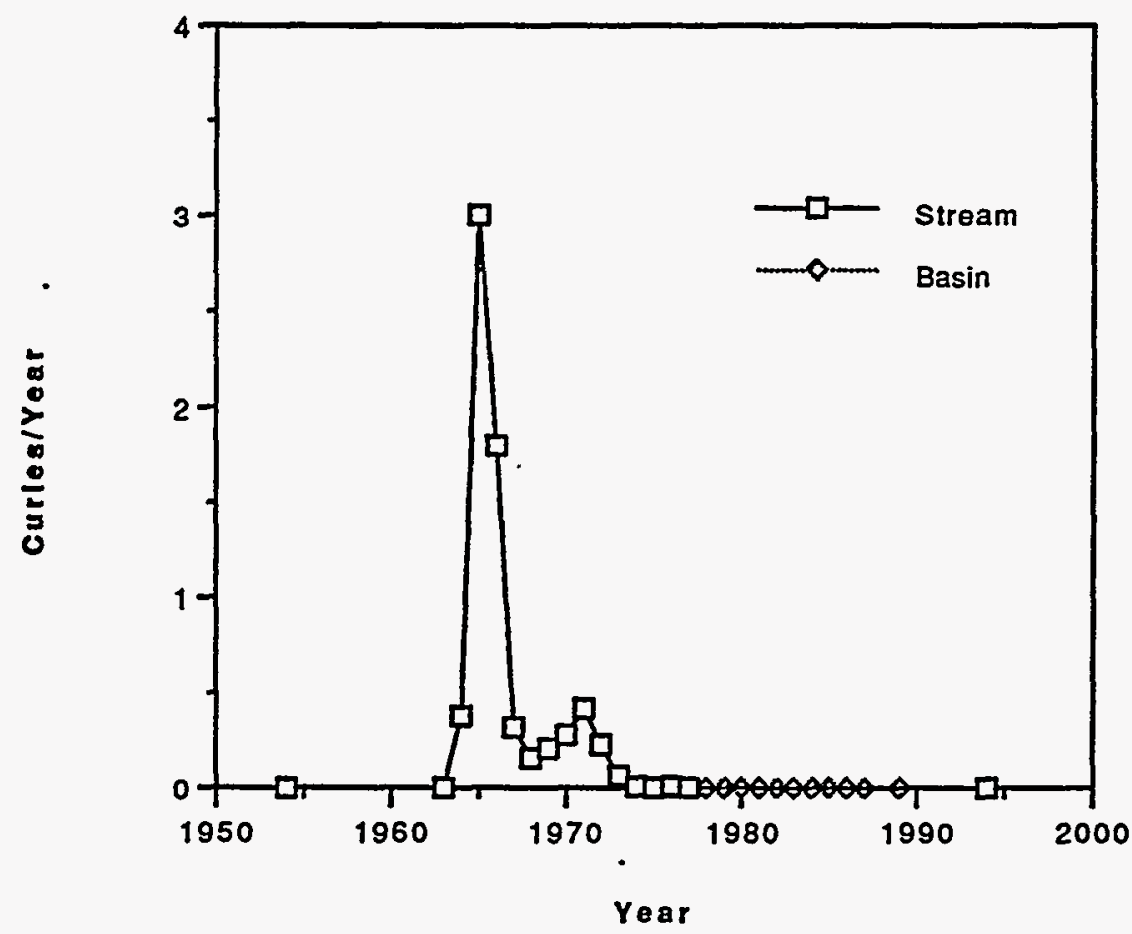

Figure 3.15. P-Area Cr-51 Releases to Streams and Basins

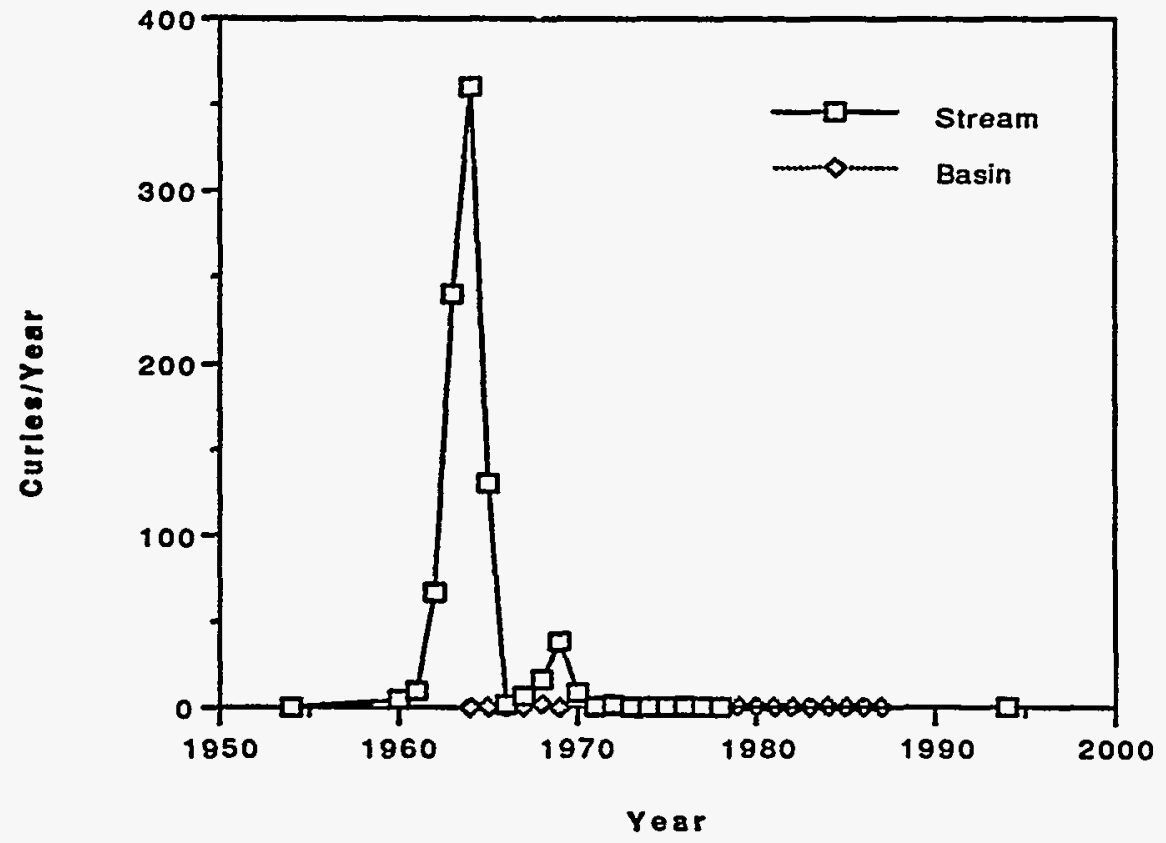


Figure 3.16. P-Area Co-60 Releases to Streams and Basins

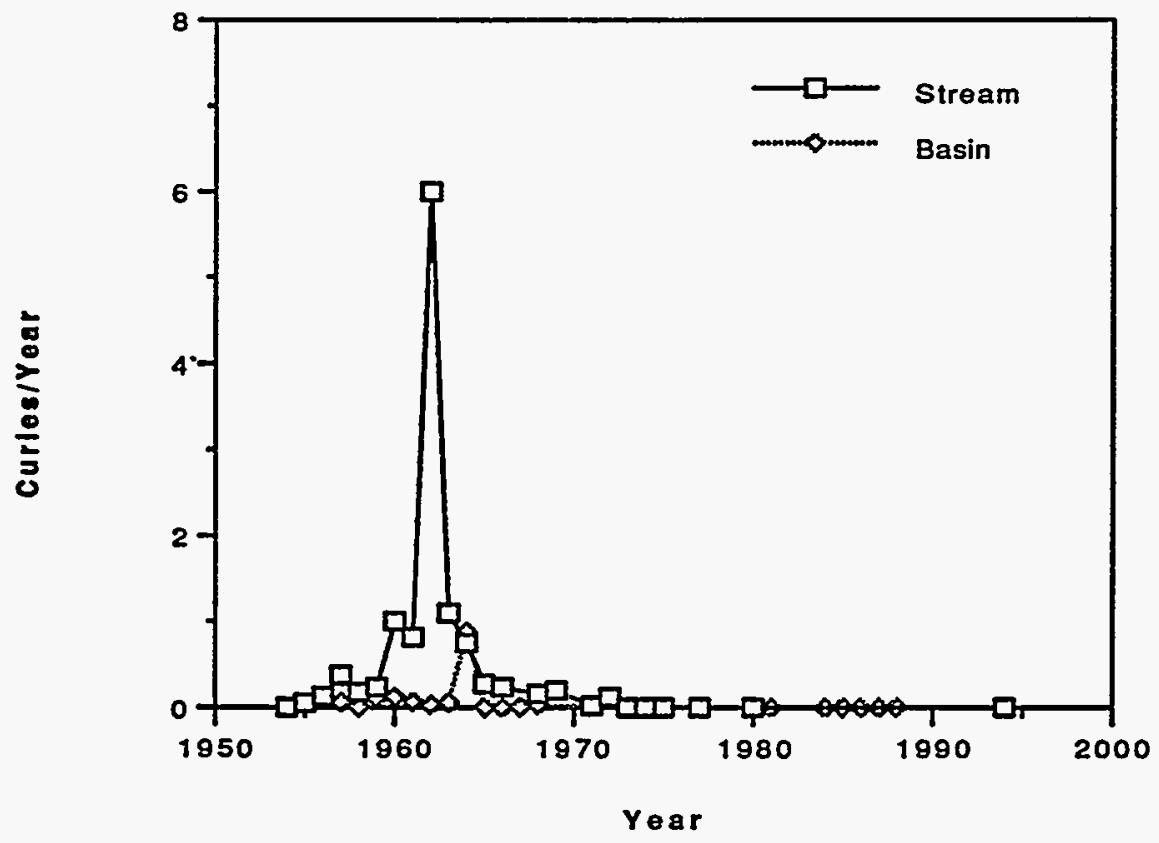

- Figure 3.17. P-Area Zn-65 Releases to Streams

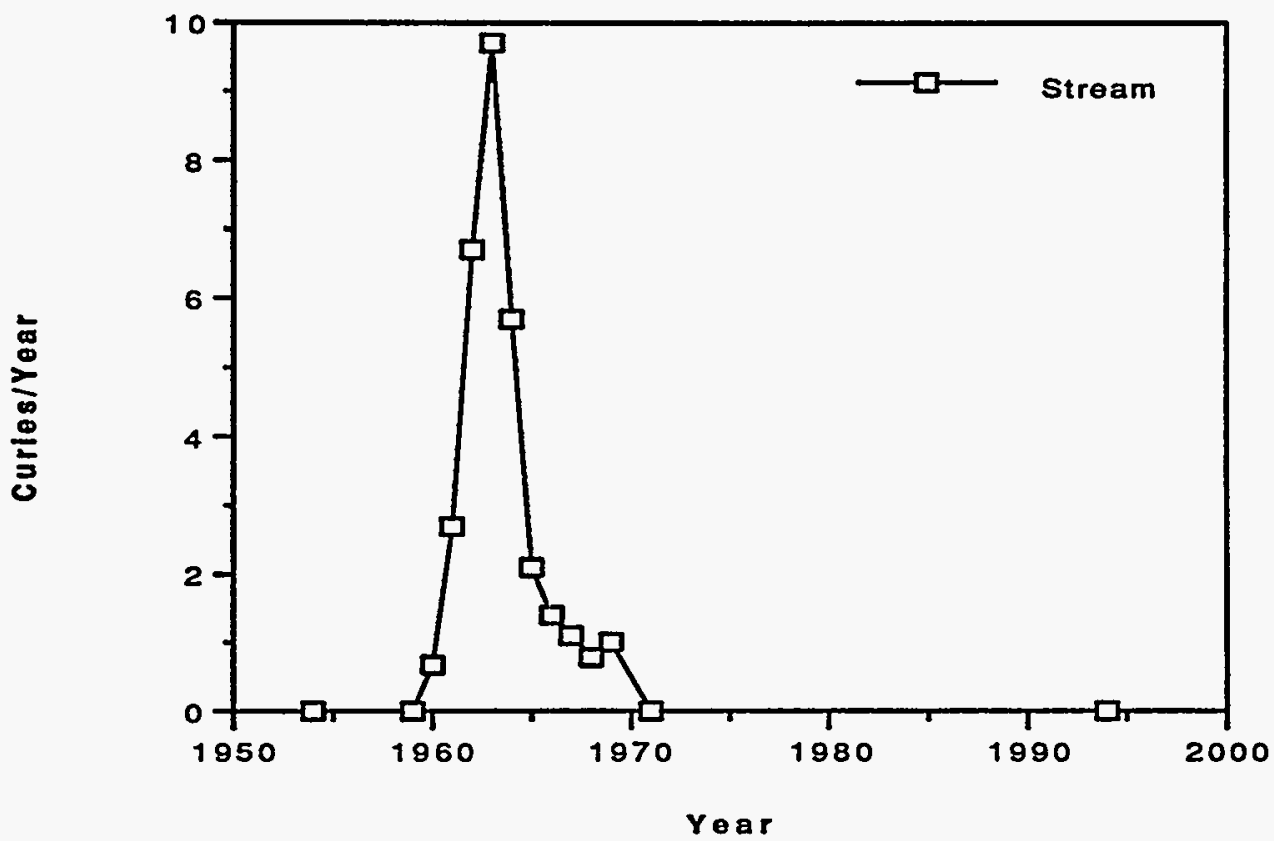


Chapter 3. Releases and Stored Inventories of Activation Products at SRS

Table 3-4. P-Area Releases

Releases to Streams $(\mathrm{Cl})$

Releases to Basins (Ci)

\begin{tabular}{|c|c|c|c|c|c|c|c|c|}
\hline Year & $\overline{P-32}$ & $\mathrm{Cr}_{\mathrm{r}-51}$ & $\mathrm{Co}_{0}-60$ & $\mathrm{Zn}-65$ & P-32 & $\mathrm{Cr}_{\mathrm{r}-51}$ & $C 0-60$ & Zn-65 \\
\hline 1954 & & & & & & & & \\
\hline 1955 & & & $5.6 \times 10^{-2}$ & & & & & \\
\hline 1956 & & & $1.3 \times 10^{-1}$ & & & & & \\
\hline 1957 & & & $3.8 \times 10^{-1}$ & & & & $6.4 \times 10^{-2}$ & \\
\hline 1958 & & & $1.8 \times 10^{-1}$ & & & & $2.0 \times 10^{-3}$ & \\
\hline 1959 & & & $2.4 \times 10^{-1}$ & & & & $1.1 \times 10^{-1}$ & \\
\hline 1960 & & $4.2 \times 10^{0}$ & $1.0 \times 10^{0}$ & $6.7 \times 10^{-1}$ & & & $1.2 \times 10^{-1}$ & \\
\hline 1961 & & $9.5 \times 10^{0}$ & $8.2 \times 10^{-1}$ & $2.7 \times 10^{0}$ & & & $6.6 \times 10^{-2}$ & \\
\hline 1962 & & $6.7 \times 10^{1}$ & $6.0 \times 10^{0}$ & $6.7 \times 10^{0}$ & & & $3.0 \times 10^{-2}$ & \\
\hline 1963 & & $2.4 \times 10^{2}$ & $1.1 \times 10^{0}$ & $9.7 \times 10^{0}$ & & & $6.0 \times 10^{-2}$ & \\
\hline 1964 & $3.8 \times 10^{-1}$ & $3.6 \times 10^{2}$ & $7.5 \times 10^{-1}$ & $5.7 \times 10^{0}$ & & $6.0 \times 10^{-2}$ & $8.8 \times 10^{-1}$ & \\
\hline 1965 & $3.0 \times 10^{0}$ & $1.3 \times 10^{2}$ & $2.8 \times 10^{-1}$ & $2.1 \times 10^{0}$ & & $4.0 \times 10^{-3}$ & $3.0 \times 10^{-3}$ & \\
\hline 1966 & $1.8 \times 10^{0}$ & $1.3 \times 10^{0}$ & $2.4 \times 10^{-1}$ & $1.4 \times 10^{0}$ & & $2.0 \times 10^{-3}$ & $3.0 \times 10^{-3}$ & \\
\hline 1967 & $3.2 \times 10^{-1}$ & $6.3 \times 10^{0}$ & & $1.1 \times 10^{0}$ & & & $5.0 \times 10^{-3}$ & \\
\hline 1968 & $1.6 \times 10^{-1}$ & $1.6 \times 10^{1}$ & $1.6 \times 10^{-1}$ & $7.8 \times 10^{-1}$ & & $1.8 \times 10^{0}$ & $3.0 \times 10^{-2}$ & $1.8 \times 10^{-1}$ \\
\hline 1969 & $2.1 \times 10^{-1}$ & $3.8 \times 10^{1}$ & $2.0 \times 10^{-1}$ & $1.0 \times 10^{0}$ & & & & \\
\hline 1970 & $2.8 \times 10^{-1}$ & $8.3 \times 10^{0}$ & & & & & & \\
\hline 1971 & $4.2 \times 10^{-1}$ & $1.6 \times 10^{-1}$ & $2.1 \times 10^{-2}$ & $1.2 \times 10^{-3}$ & & & & \\
\hline 1972 & $2.3 \times 10^{-1}$ & $1.2 \times 10^{0}$ & $1.2 \times 10^{-1}$ & & & & & \\
\hline 1973 & $6.7 \times 10^{-2}$ & $28 \times 10^{-1}$ & $2.0 \times 10^{-3}$ & & & & & \\
\hline 1974 & $1.0 \times 10^{-2}$ & $1.1 \times 10^{-1}$ & $1.0 \times 10^{-3}$ & & & & & \\
\hline 1975 & $2.0 \times 10^{-3}$ & $4.8 \times 10^{-2}$ & $1.0 \times 10^{-3}$ & & & & & \\
\hline 1976 & $9.0 \times 10^{-3}$ & $1.8 \times 10^{-1}$ & & & & & & \\
\hline 1977 & $27 \times 10^{-3}$ & $7.0 \times 10^{-2}$ & $6.0 \times 10^{-5}$ & & $\cdot$ & & & \\
\hline 1978 & & $1.5 \times 10^{-2}$ & & & $2.7 \times 10^{-3}$ & $8.9 \times 10^{-3}$ & & \\
\hline 1979 & & & & & $1.5 \times 10^{-3}$ & $1.7 \times 10^{-1}$ & & \\
\hline 1980 & & & $8.3 \times 10^{-5}$ & & $9.4 \times 10^{-4}$ & $1.1 \times 10^{-1}$ & & \\
\hline 1981 & & & & & $1.6 \times 10^{-3}$ & $8.4 \times 10^{-2}$ & $1.0 \times 10^{-6}$ & \\
\hline 1982 & & & & & $4.9 \times 10^{-4}$ & $1.4 \times 10^{-1}$ & & \\
\hline 1983 & & & & & $1.2 \times 10^{-3}$ & $7.9 \times 10^{-2}$ & & \\
\hline 1984 & & & & & $1.3 \times 10^{-4}$ & $2.2 \times 10^{-1}$ & $6.5 \times 10^{-5}$ & \\
\hline 1985 & & & & & $4.9 \times 10^{-4}$ & $9.6 \times 10^{-2}$ & $3.6 \times 10^{-4}$ & \\
\hline 1986 & & & & & $8.5 \times 10^{-5}$ & $9.6 \times 10^{-2}$ & $5.7 \times 10^{-5}$ & \\
\hline 1987 & & & & & $1.2 \times 10^{-5}$ & $4.7 \times 10^{-2}$ & $4.9 \times 10^{-4}$ & \\
\hline 1988 & & & & & & & $1.3 \times 10^{-5}$ & \\
\hline 1989 & & & & & $1.9 \times 10^{-4}$ & & & \\
\hline 1990 & & & & & & & & \\
\hline 1991 & & & & & & & & \\
\hline 1992 & & & & & & & & \\
\hline 1993 & & & & & & & & \\
\hline 1994 & & & & & & & & \\
\hline Total & $6.9 \times 10^{0}$ & $8.8 \times 10^{2}$ & $1.2 \times 10^{1}$ & $3.2 \times 10^{1}$ & $9.3 \times 10^{-3}$ & $2.9 \times 10^{0}$ & $1.4 \times 10^{0}$ & $1.8 \times 10^{-1}$ \\
\hline
\end{tabular}


and seepage basins from $P$ Area are presented in Figures 3.14 through 3.17 and in Table 3-4.

The total measured aqueous releases from $P$ Reactor to Steel Creek/PAR Pond during the reactor's operational lifetime were $6.9 \times 10^{0} \mathrm{Ci}$ of ${ }^{32} \mathrm{P}, 8.8 \times 10^{2} \mathrm{Ci}$ of ${ }^{51} \mathrm{Cr}, 1.2 \times$ $10^{1} \mathrm{Ci}$ of ${ }^{60} \mathrm{Co}$, and $3.2 \times 10^{1} \mathrm{Ci}$ of ${ }^{65} \mathrm{Zn}$. Cumulative releases to seepage basins totaled $9.3 \times 10^{-3} \mathrm{Ci}$ of ${ }^{32} \mathrm{P}, 2.9$ $\times 10^{0} \mathrm{Ci}$ of ${ }^{51} \mathrm{Cr}, 1.4 \times 10^{0} \mathrm{Ci}$ of ${ }^{60} \mathrm{Co}$, and $1.8 \times 10^{-1} \mathrm{Ci}$ of ${ }^{65} \mathrm{Zn}$. The greatest annual release of ${ }^{32} \mathrm{P}$ to Steel Creek/ PAR Pond, $3.0 \times 10^{0} \mathrm{Ci}$, occurred in 1965 ; of ${ }^{51} \mathrm{Cr}, 3.6 \times$ $10^{2} \mathrm{Ci}$, in 1964; of ${ }^{60} \mathrm{Co}, 6.0 \times 10^{\circ} \mathrm{Ci}$, in 1962 ; and of ${ }^{65} \mathrm{Zn}, 9.7 \times 10^{\circ} \mathrm{Ci}$, in 1963 .

\section{R Reactor}

R Reactor was the first operational production reactor at SRS. It operated from late 1953 until 1964 when it was shut down. Reactor basin water was discharged into Lower Three Runs Creek from 1954 to 1958, into PAR Pond from 1958 to 1964, and into a seepage basin system from 1957 to 1964 . R Reactor had six seepage basins, designated 904-103G, -104G, -57G, -58G, -59G, and -60G.

The original seepage basin, 904-103G, was used only from June to December 1957. Use of this basin was terminated because of surface outcropping and leakage into an abandoned sewer. The basin was backfilled in 1958 . Basins 904-104G, -57G, -58G, and -59G-in use from 1957 to 1960 -were deactivated, backfilled, and covered with asphalt in 1960. Basin 904-60G-in use from 1958 to 1964 -was backfilled in 1977.

Reactor heat exchanger cooling water and miscellaneous effluents were discharged to Lower Three Runs Creek from 1954 to 1958. After 1958, these effluents were discharged to PAR Pond, which was constructed by damming Lower Three Runs Creek. Initially, R Reactor effluents were discharged directly to PAR Pond. Beginning in 1961, a canal and pond system that eventually drained into PAR Pond (Figure 3.1) replaced direct discharges into PAR Pond. Releases to stream and seepage basins from R Area are presented in Figures 3.18 through 3.21 and in Table 35.

The total measured aqueous releases from $\mathrm{R}$ Reactor to Lower Three Runs/PAR Pond during the reactor's operational lifetime were $6.2 \times 10^{-1} \mathrm{Ci}$ of ${ }^{32} \mathrm{P}, 5.5 \times 10^{2} \mathrm{Ci}$ of ${ }^{51} \mathrm{Cr}, 1.1 \times 10^{1} \mathrm{Ci}$ of ${ }^{60} \mathrm{Co}$, and $3.8 \times 10^{1} \mathrm{Ci}$ of ${ }^{65} \mathrm{Zn}$. Cumulative releases to seepage basins totaled $1.0 \times 10^{-2} \mathrm{Ci}$ of ${ }^{32} \mathrm{P}$ and $3.2 \times 10^{0} \mathrm{Ci}$ of ${ }^{51} \mathrm{Cr}$. The greatest annual release of ${ }^{32} \mathrm{P}$ to Lower Three Runs/PAR Pond, $6.2 \times 10^{-1}$ $\mathrm{Ci}$, occurred in 1964; of ${ }^{51} \mathrm{Cr}, 3.4 \times 10^{2} \mathrm{Ci}$, in 1964; of
${ }^{60} \mathrm{Co}, 2.4 \times 10^{0} \mathrm{Ci}$, in 1963 ; and of ${ }^{65} \mathrm{Zn}, 1.6 \times 10^{1} \mathrm{Ci}$, in 1963.

\section{Summary of Reactor Releases}

The total measured stream releases of activation products from reactor areas through 1994 were $3.7 \times 10^{1} \mathrm{Ci}$ of ${ }^{32} \mathrm{P}, 4.5$ $\times 10^{3} \mathrm{Ci}$ of ${ }^{51} \mathrm{Cr}, 6.7 \times 10^{1} \mathrm{Ci}$ of ${ }^{60} \mathrm{Co}$, and $1.4 \times 10^{2} \mathrm{Ci}$ of ${ }^{65} \mathrm{Zn}$. The total measured basin releases were $1.6 \times 10^{2} \mathrm{Ci}$ of ${ }^{32} \mathrm{P}, 6.0 \times 10^{2} \mathrm{Ci}$ of ${ }^{51} \mathrm{Cr}, 8.0 \times 10^{0} \mathrm{Ci}$ of ${ }^{60} \mathrm{Co}$, and $5.0 \times 10^{0}$ $\mathrm{Ci}$ of ${ }^{65} \mathrm{Zn}$.

\section{Separations and Liquid Waste Facilities}

Two chemical separations facilities and their associated liquid-waste storage facilities are located near the center of the Site (Figure 3.1). The two separations areas are identified by the letter designations $F$ and $H$. In these areas, the products of interest from reactor irradiation are chemically separated and purified from waste products.

\section{Facility Operations}

Two chemical separations facilities were used to reprocess irradiated fuel and targets in canyon buildings (221-F and 221-H). Irradiated materials were dissolved and the products of interest chemically separated and purified from waste fission and activation products. Occasional special campaigns for the production of radionuclides such as ${ }^{238} \mathrm{Pu}$ and ${ }^{252} \mathrm{Cf}$ have occurred.

Beginning in late $1954,{ }^{239} \mathrm{Pu},{ }^{237} \mathrm{~Np}$, and ${ }^{238} \mathrm{U}$ were recovered from irradiated ${ }^{238} \mathrm{U}$ targets in $\mathrm{F}$ Area, which used the Purex chemical extraction process. In $\mathrm{H}$ Area, ${ }^{239} \mathrm{Pu}$ and ${ }^{238} \mathrm{U}$ were recovered from ${ }^{238} \mathrm{U}$ targets by the Purex process during 1955 to 1959 . The H-Area facility then was modified to recover ${ }^{235} \mathrm{U}$ from irradiated enriched uranium fuel. A further modification in 1963 allowed the recovery of ${ }^{237} \mathrm{~Np}$ from the fuel; the HM process (H Modified Purex) was used for chemical extraction of the uranium. Also in $\mathrm{H}$ Area, the Frames process was used occasionally to recover ${ }^{238} \mathrm{Pu}$ and ${ }^{237} \mathrm{~Np}$ from special target elements. This process used ion exchange for separations and purification.

Waste facilities in or adjacent to the separations facilities were designed for liquid-waste handling. Depending on activity level, liquid wastes were stored in tanks or sent to seepage basins or the ETF. In November 1988, the ETF became operational to treat wastes previously sent to seep- 
Figure 3.18. R-Area P-32 Releases to Streams

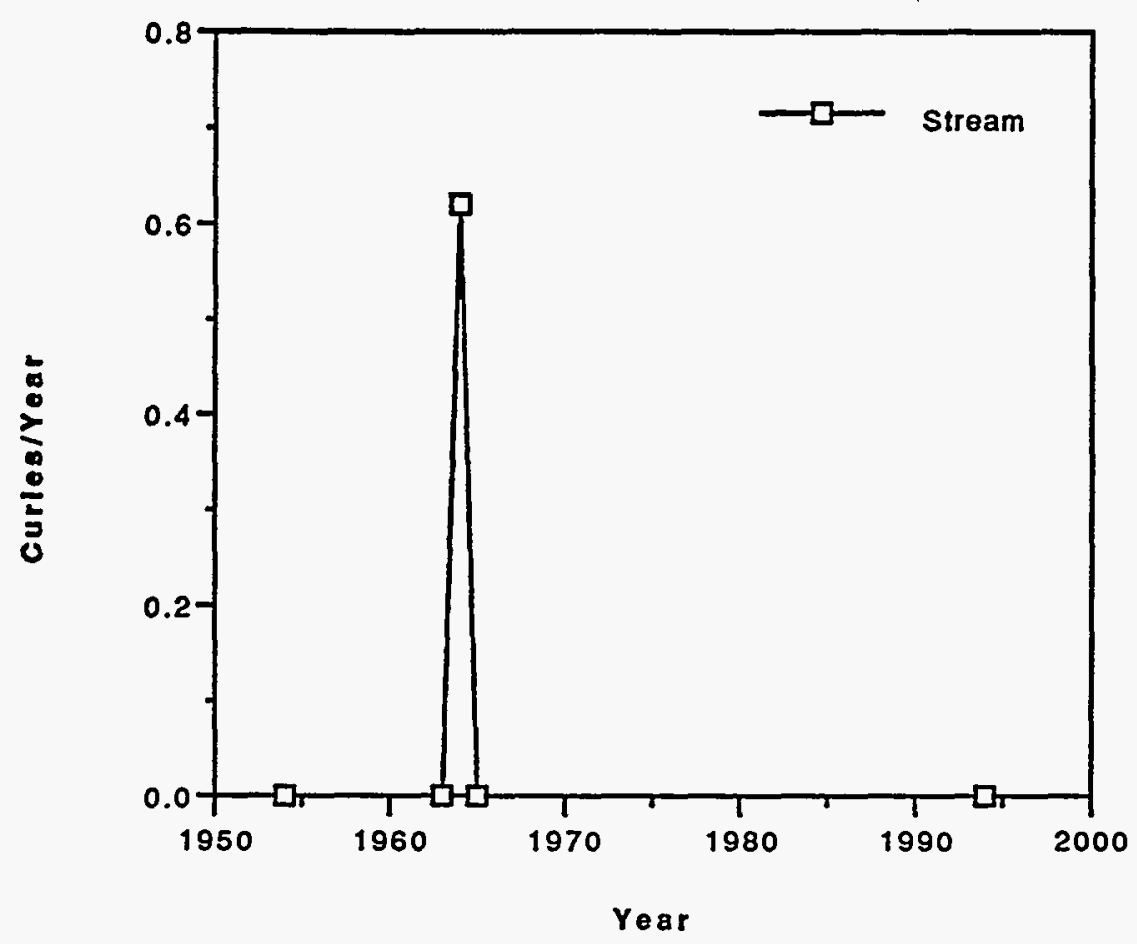

Figure 3.19. R-Area Cr-51 Releases to Streams and Basins

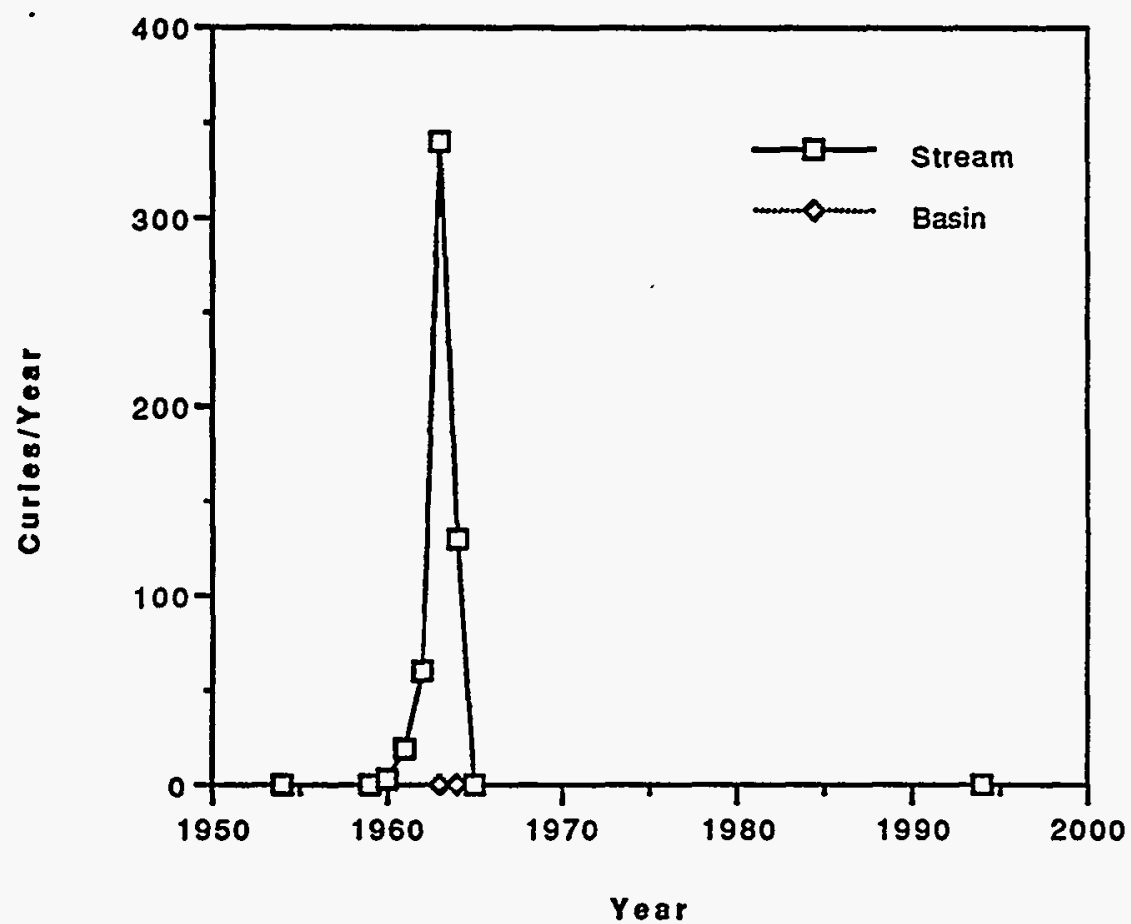


Figure 3.20. R-Area Co-60 Releases to Streams and Basins

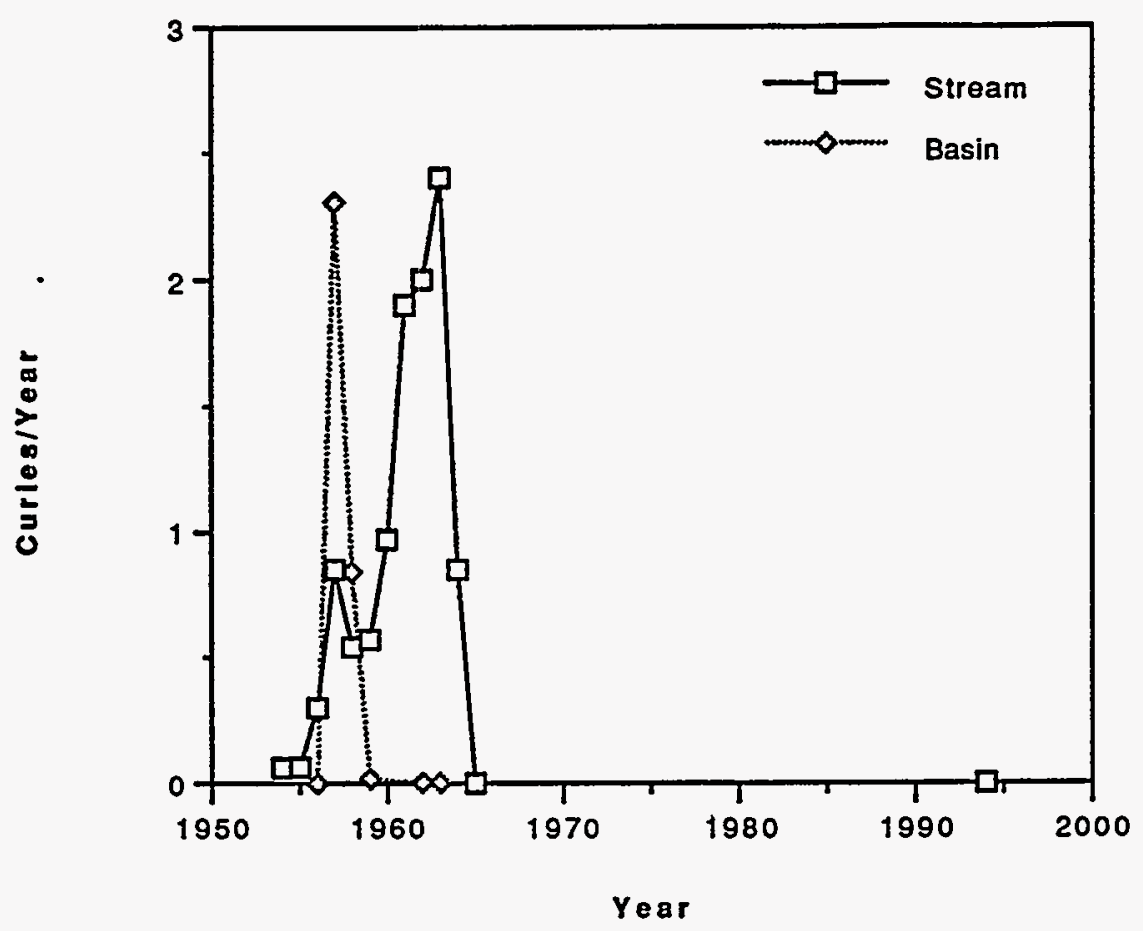

Figure 3.21. R-Area Zn-65 Releases to Streams

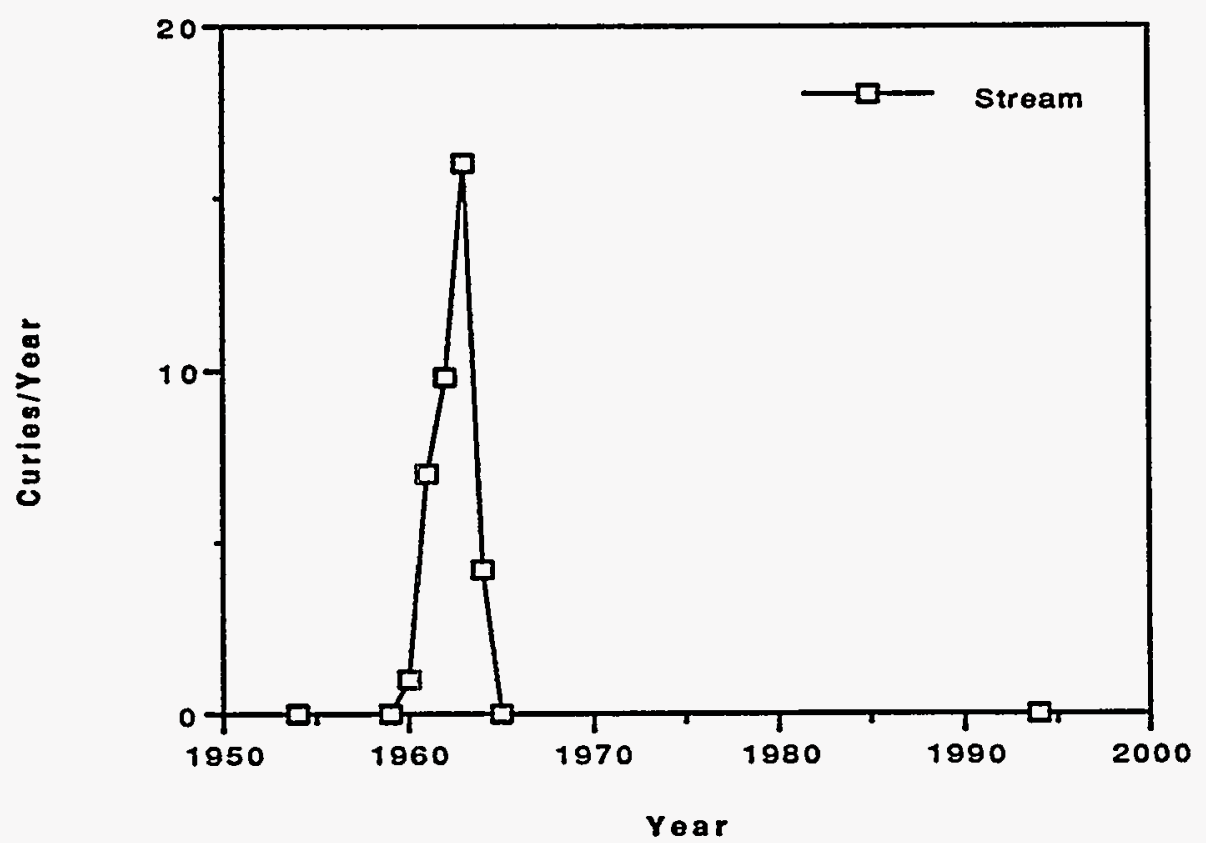


Table 3-5. R-Area Releases

\begin{tabular}{|c|c|c|c|c|c|c|c|c|}
\hline \multicolumn{5}{|c|}{ Releases to Streams (Ci) } & \multicolumn{4}{|c|}{ Releases to Basins (Ci) } \\
\hline Year & P-32 & Cr-51 & $C 0.60$ & $2 n-65$ & $\mathrm{P}-32$ & $\mathrm{Cr}_{\mathrm{T}-51}$ & $\mathrm{C} 0-60$ & Zn-65 \\
\hline 1954 & & & $6.0 \times 10^{-2}$ & & & & & \\
\hline 1955 & & & $6.4 \times 10^{-2}$ & & & & & \\
\hline 1956 & & & $3.0 \times 10^{-1}$ & & & & & \\
\hline 1957 & & & $8.5 \times 10^{-1}$ & & & $2.3 \times 10^{0}$ & & \\
\hline 1958 & & & $5.4 \times 10^{-1}$ & & & $8.4 \times 10^{-1}$ & & \\
\hline 1959 & & - & $5.7 \times 10^{-1}$ & & & $1.8 \times 10^{-2}$ & & \\
\hline 1960 & • & $2.8 \times 10^{0}$ & $9.7 \times 10^{-1}$ & $1.0 \times 10^{0}$ & & & & \\
\hline 1961 & & $1.9 \times 10^{1}$ & $1.9 \times 10^{0}$ & $7.0 \times 10^{0}$ & & & & \\
\hline $1962^{\circ}$ & & $6.0 \times 10^{1}$ & $2.0 \times 10^{0}$ & $9.8 \times 10^{0}$ & & $1.6 \times 10^{-3}$ & & \\
\hline 1963 & & $3.4 \times 10^{2}$ & $2.4 \times 10^{0}$ & $1.6 \times 10^{1}$ & & $2.0 \times 10^{-3}$ & & \\
\hline 1964 & $6.2 \times 10^{-1}$ & $1.3 \times 10^{2}$ & $8.5 \times 10^{-1}$ & $4.2 \times 10^{0}$ & $1.0 \times 10^{-2}$ & & & \\
\hline 1965 & & & & & & & & \\
\hline 1966 & & & & & & & & \\
\hline $\begin{array}{l}1967 \\
1968\end{array}$ & & & & & & & & \\
\hline 1969 & & & & & & & & \\
\hline 1970 & & & & & & & & \\
\hline 1971 & & & & & & & & \\
\hline 1972 & & & & & & & & \\
\hline 1973 & & & & & & & & \\
\hline 1974 & & & & & & & & \\
\hline 1975 & 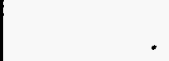 & & & & & & & \\
\hline 1976 & & & & & & & & \\
\hline $\begin{array}{l}1977 \\
1978\end{array}$ & & & & & & & & \\
\hline $\begin{array}{l}1978 \\
1979\end{array}$ & & & & & & & & \\
\hline 1980 & & & & & & & & \\
\hline 1981 & & & & & & & & \\
\hline 1982 & & & & & & & & \\
\hline 1983 & & & & & & & & \\
\hline 1984 & & & & & & & & \\
\hline 1985 & & & & & & & & \\
\hline 1986 & & & & & & & & \\
\hline 1987 & & & & & & & & \\
\hline 1988 & & & & & & & & \\
\hline 1989 & & & & & & & & \\
\hline 1990 & & & & & & & & \\
\hline 1991 & & & & & & & & \\
\hline 1992 & & & & & & & & \\
\hline 1993 & & & & & & & & \\
\hline 1994 & & & & & & & & \\
\hline Total & $6.2 \times 10^{-1}$ & $5.5 \times 10^{2}$ & $1.1 \times 10^{1}$ & $3.8 \times 10^{1}$ & $1.0 \times 10^{-2}$ & $3.2 \times 10^{0}$ & $0.0 \times 10^{0}$ & $0.0 \times 10^{0}$ \\
\hline
\end{tabular}


age basins that were closed in 1988 and have been decommissioned.

\section{Pathways for Release}

Unlike the reactor facilities, which released activation products to the environment almost exclusively through aqueous effluents, the separations facilities have released activation products through atmospheric and aqueous effluents. The aqueous releases from separations facilities were to seepage basins in $\mathrm{H}$ Area, while atmospheric releases of ${ }^{60} \mathrm{Co}$ have occurred from both canyon building stacks.

Aqueous releases occurred when residual ${ }^{51} \mathrm{Cr},{ }^{60} \mathrm{Co}$, and ${ }^{65} \mathrm{Zn}$ were present in high- and low-level aqueous waste streams. Before these wastes were stored in tanks, an evaporation process was used to reduce volume. During evaporation, part of the activation products distilled with the condensate in the evaporators. This condensate was sent to the seepage basins through November 1988, then to the ETF.

The major sources of wastewater previously discharged to the seepage basins were the overheads from the nitric acid recovery unit and the process evaporators in $\mathrm{F}$ and $\mathrm{H}$ areas. In H Area, water from the Resin Regeneration Facility and RBOF also was discharged to the seepage basin system. A flow sheet for liquid waste handling can be found in Jacobsen et al. (1973). Because of this reference's date, replacement of the seepage basins with the ETF is not shown.

\section{Emission Control}

Administrative and physical controls implemented in reactor areas in the 1960 s minimized the possibility that shortcooled fuel or targets would be sent inadvertently to the chemical separations areas. Beginning in the early 1970s, fuel and targets were controlled so their nominal cooling time was $\mathbf{2 0 0}$ days before reprocessing by the Purex or HM process.

Canyon building exhaust air passes through sand filters to remove particulate radioactivity prior to discharge from a 61-meter stack. Air and fumes from process vessels are exhausted through a variety of scrubbers, filters, or silver nitrate reactors to remove specific gaseous contaminants before final filtration and discharge from the stack. The 61-meter stack in each facility provides sufficient loft to the offgases to ensure that activation products (and other radionuclides) are dissipated into very low concentrations over a large area. This minimizes exposure to people in and around the facility.
For liquid releases, results of radioactivity measurements determined whether liquids were discharged to the ETF (previously seepage basins) or to waste tanks.

\section{Release Monitoring}

Atmospheric releases of activation products from separations facilities have been sampled since start up. Reprocessing irradiated material began in F Canyon in November 1954 and in $H$ Canyon in July 1955 . The only activation product identified was ${ }^{60} \mathrm{Co}$, which was seen only a few times. Other activation products (and ${ }^{60} \mathrm{Co}$ ) would have contributed to the unidentified beta portion of releases.

Aqueous releases of activation products to seepage basins have been quantified. Several techniques were used to monitor aqueous releases. Process cooling water in F Area was monitored in-line for beta-gamma activity. In $\mathrm{H}$ Area, batches of process cooling water were monitored prior to release. When liquid effluents were released to seepage basins, they were sampled continuously. Samples were collected weekly and analyzed by gamma spectrometry. Effluent Treatment Facility (ETF) discharges were sampled before release to Upper Three Runs Creek (Taylor 1989).

\section{History of Measured Releases}

Atmospheric releases of radioactivity, as well as releases to streams and seepage basins, have been monitored since the start up of the chemical separations facilities (Cummins et al. 1991). In most years, activation products were not quantified individually, but their radioactivity was included in unidentified beta-gamma.

\section{F-Area Separations}

Aqueous wastes from $\mathrm{F}$ Canyon initially were sent to waste tanks and a seepage basin designated 904-49G, also known as Old F Area Seepage Basin. The capacity of this basin proved to be inadequate. It was abandoned in 1955 after three additional seepage basins were constructed. The new basins, designated $904-41 G,-42 G$, and $-43 G$, were in use from 1955 to 1988, when wastewaters were diverted to the ETF. The latter basins also were known as F Seepage Basins 1,2 , and 3 .

Additionally, an earthen retention basin (281-3F) was used from 1955 to 1973 to temporarily contain water potentially contaminated by process upsets. Use of a lined retention basin was implemented in 1973. 


\section{Releases to Atmosphere}

The only activation product measured in atmospheric releases from $F$ Area was ${ }^{60} \mathrm{Co}$, which was reported in four different years. The total release of ${ }^{60} \mathrm{Co}$ was 1.9 $\times 10^{-2} \mathrm{Ci}$, with most occurring in 1971. Measured annual releases are shown in Table 3-6.

\section{Releases to Streams}

Cooling water for portions of the F-Area separations process is pumped from deep wells and discharged to Fourmile Branch after use. This water has been used in the "once through" or "segregated" cooling-water systems that control temperatures in the separations process or waste evaporators. Because of the possibility of cooling-coil leakage, these cooling-water streams have the potential to contain measurable amounts of radioactivity. Cooling coils are used in the head-end dissolvers; hence, a mixture of many fission and activation products is available as a potential cooling system contaminant.

To minimize releases of radioactivity into the cooling system when a leak does occur, positive pressure is maintained in the cooling coils in all process vessels. After the water has been used, it is monitored and released to Fourmile Branch. Should activity levels in the water preclude the discharge of the water to the creek, the contaminated water is held in a plastic lined "diversion" basin and transferred to either the H Area waste tank farm or the ETF for processing. In the past, diversion basin water that was too radioactive for release to the stream was pumped to the seepage basins. No activation products were identified as constituents of the releases from $F$ Area to stream.

\section{Releases to F-Area Seepage Basins}

Cobalt -60 was released to $F$ Area seepage basins in 1969,1970 , and 1971. The total activity was $1.2 \times$ $10^{-1} \mathrm{Ci}$ with the largest release, $9.0 \times 10^{-2} \mathrm{Ci}$, occurring in 1970. Releases for individual years are listed in Table 3-8.

\section{H-Area Separations}

H Canyon has been operational since July 1955 . In addition to the general chemical separations operations, $H$ Area also includes the ETF and the RBOF, with an adjacent regeneration facility for resins from other areas. Certain offsite noncommercial irradiated fuels are stored underwater in the RBOF, as are some SRS fuel elements that have failed. This facility is equipped to disassemble and cut fuel for inspection.
Aqueous wastes from $\mathrm{H}$ Canyon were sent to tanks and to four seepage basins, designated 904-44G, $45 \mathrm{G},-46 \mathrm{G}$, and $-56 \mathrm{G}$. The basins, also known as $\mathrm{H}$ Seepage Basins 1, 2, 3, and 4, were used from 1955 to: 1988, when wastewaters were diverted to the ETF. Basin 904-46G has been inactive since 1962.

Also, an earthen retention basin, designated 281-3H, was used from 1955 to 1973 to temporarily contain water potentially contaminated by process upsets. Use of a lined retention basin was implemented in 1973.

\section{Releases to Atmosphere}

The only activation product measured in atmospheric releases from $\mathrm{H}$ Area was ${ }^{60} \mathrm{Co}$, which was reported in two different years. The total release of ${ }^{60} \mathrm{Co}$ was $6.2 \times 10^{-4} \mathrm{Ci}$, with most occurring in 1971. Measured annual releases are shown in Table 3-6.

\section{Releases to Streams}

As in F Area, clean well water is pumped through pressurized coils in evaporators and process tanks to control temperatures, then discharged into a process sewer that empties into Fourmile Branch. Water from the cooling system is monitored before release to Fourmile Branch. No release of activation product activity has been reported.

\section{Releases to H-Area Seepage Basins}

The total measured release of ${ }^{51} \mathrm{Cr}$ to the $\mathrm{H}$ seepage basins was $1.1 \times 10^{2} \mathrm{Ci}$; of ${ }^{60} \mathrm{Co}, 5.1 \times 10^{\circ} \mathrm{Ci}$; and of ${ }^{65} \mathrm{Zn}, 2.9 \times 10^{0} \mathrm{Ci}$. Activation product releases occurred in $\mathrm{H}$ Area primarily because of the presence of the Resin Regeneration Facility, which removed fission and activation products that had been captured by ion exchange resins in the reactor disassembly basins. The release information is presented in Figures 3.22 through 3.24 and Table 3-7.

The ETF became operational in November 1988 to receive aqueous wastes previously discharged to the separations area seepage basins.

\section{Effuent Treatment Facility}

All the low-level liquid wastes formerly discharged to the F-Area and H-Area seepage basins are processed in the ETF. Treated aqueous wastes from the ETF are discharged to Upper Three Runs Creek. No activation product releases have been reported since the ETF became operational. 
Assessment of Activation Products

Table 3-6. Atmospheric Releases of Co-60

\begin{tabular}{ccc} 
Year & \multicolumn{3}{c}{ Area } \\
\hline A & F & H
\end{tabular}

1954

1955

1956

1957

1958

1959

1960

1961

1962

1963

1964

1965

1966

1967

1968

1969

1970

1971

1972

1973

1974

1975

1976

1977

1978

1979

1980

1981

1982

1983

1984

1985

1986

1987

1988

1989

1990

1991

1992

1993

1994

Total
$3.9 \times 10^{-2}$

$1.1 \times 10^{-2}$

$2.8 \times 10^{-3}$

$2.6 \times 10^{-3}$

$7.1 \times 10^{-3}$

$1.8 \times 10^{-3}$

$3.9 \times 10^{-3}$

$1.1 \times 10^{-3}$

$1.3 \times 10^{-4}$

$3.8 \times 10^{-4}$

$3.8 \times 10^{-4}$

$4.0 \times 10^{-4}$

$6.2 \times 10^{-4}$

$8.9 \times 10^{-5}$

$4.4 \times 10^{-5}$

$1.7 \times 10^{-4}$

$5.4 \times 10^{-5}$

$1.9 \times 10^{-2}$

$9.0 \times 10^{-5}$

$6.2 \times 10^{-4}$

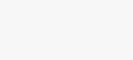

$7.0 \times 10^{-6} \quad 1.0 \times 10^{-6}$

$3.0 \times 10^{-6}$

$4.0 \times 10^{-6}$

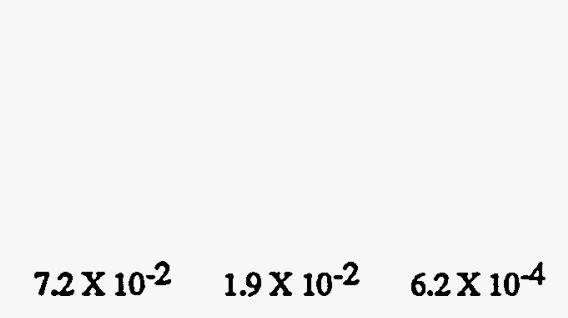

Table 3-7. H-Area Releases

\begin{tabular}{|c|c|c|c|}
\hline \multirow[b]{2}{*}{ Year } & \multicolumn{3}{|c|}{ Release to Basins (Ci) } \\
\hline & $\mathrm{Cr}_{\mathrm{r}-51}$ & $\mathrm{C} 0-60$ & $\overline{Z n-65}$ \\
\hline \multicolumn{4}{|l|}{1954} \\
\hline \multicolumn{4}{|l|}{1955} \\
\hline \multicolumn{4}{|l|}{1956} \\
\hline \multicolumn{4}{|l|}{1957} \\
\hline \multicolumn{4}{|l|}{1958} \\
\hline \multicolumn{4}{|l|}{1959} \\
\hline \multicolumn{4}{|l|}{1960} \\
\hline \multicolumn{4}{|l|}{1961} \\
\hline \multicolumn{4}{|l|}{1962} \\
\hline \multicolumn{4}{|l|}{1963} \\
\hline \multicolumn{4}{|l|}{1964} \\
\hline \multicolumn{4}{|l|}{1965} \\
\hline \multicolumn{4}{|l|}{1966} \\
\hline \multicolumn{4}{|l|}{1967} \\
\hline \multicolumn{4}{|l|}{1968} \\
\hline 1969 & \multicolumn{3}{|c|}{$6.6 \times 10^{-1}$} \\
\hline 1970 & \multicolumn{3}{|c|}{$3.2 \times 10^{-1}$} \\
\hline 1971 & $2.5 \times 10^{1}$ & $4.2 \times 10^{-1}$ & \\
\hline 1972 & $3.0 \times 10^{1}$ & $3.0 \times 10^{-2}$ & \\
\hline 1973 & $1.4 \times 10^{1}$ & $4.0 \times 10^{-2}$ & \\
\hline 1974 & $7.7 \times 10^{0}$ & $4.9 \times 10^{-1}$ & $7.6 \times 10^{-1}$ \\
\hline 1975 & $4.5 \times 10^{0}$ & $4.1 \times 10^{-1}$ & $5.7 \times 10^{-1}$ \\
\hline 1976 & $6.0 \times 10^{0}$ & $4.7 \times 10^{-1}$ & $4.4 \times 10^{-1}$ \\
\hline 1977 & $6.0 \times 10^{0}$ & $4.0 \times 10^{-1}$ & $5.3 \times 10^{-1}$ \\
\hline 1978 & $1.4 \times 10^{0}$ & $1.7 \times 10^{-1}$ & $5.4 \times 10^{-2}$ \\
\hline 1979 & $7.8 \times 10^{-1}$ & $1.0 \times 10^{-1}$ & $8.0 \times 10^{-2}$ \\
\hline 1980 & $1.1 \times 10^{0}$ & $2.2 \times 10^{-1}$ & $1.4 \times 10^{-1}$ \\
\hline 1981 & $2.1 \times 10^{0}$ & $1.6 \times 10^{-1}$ & $7.4 \times 10^{-2}$ \\
\hline 1982 & $2.1 \times 10^{0}$ & $2.6 \times 10^{-1}$ & $9.1 \times 10^{-2}$ \\
\hline 1983 & $1.1 \times 10^{0}$ & $2.2 \times 10^{-1}$ & $9.5 \times 10^{-2}$ \\
\hline 1984 & $5.7 \times 10^{0}$ & $2.7 \times 10^{-1}$ & $1.0 \times 10^{-2}$ \\
\hline 1985 & $3.6 \times 10^{0}$ & $2.8 \times 10^{-1}$ & $3.0 \times 10^{-3}$ \\
\hline 1986 & $4.4 \times 10^{-1}$ & $1.3 \times 10^{-1}$ & $5.2 \times 10^{-2}$ \\
\hline 1987 & $4.2 \times 10^{-2}$ & $1.3 \times 10^{-2}$ & $2.1 \times 10^{-2}$ \\
\hline 1988 & $7.1 \times 10^{-4}$ & $5.9 \times 10^{-4}$ & $4.7 \times 10^{-3}$ \\
\hline 1989 & & & \\
\hline 1990 & & & \\
\hline 1991 & & & \\
\hline 1992 & & & \\
\hline 1993 & & & \\
\hline 1994 & & & \\
\hline Total & $1.1 \times 10^{2}$ & $5.1 \times 10^{0}$ & $2.9 \times 10^{0}$ \\
\hline
\end{tabular}


Chapter 3. Releases and Stored Inventories

of Activation Products at SRS

WSRC-TR-95-0422

Figure 3.22. H-Area Cr-51 Releases to Basins

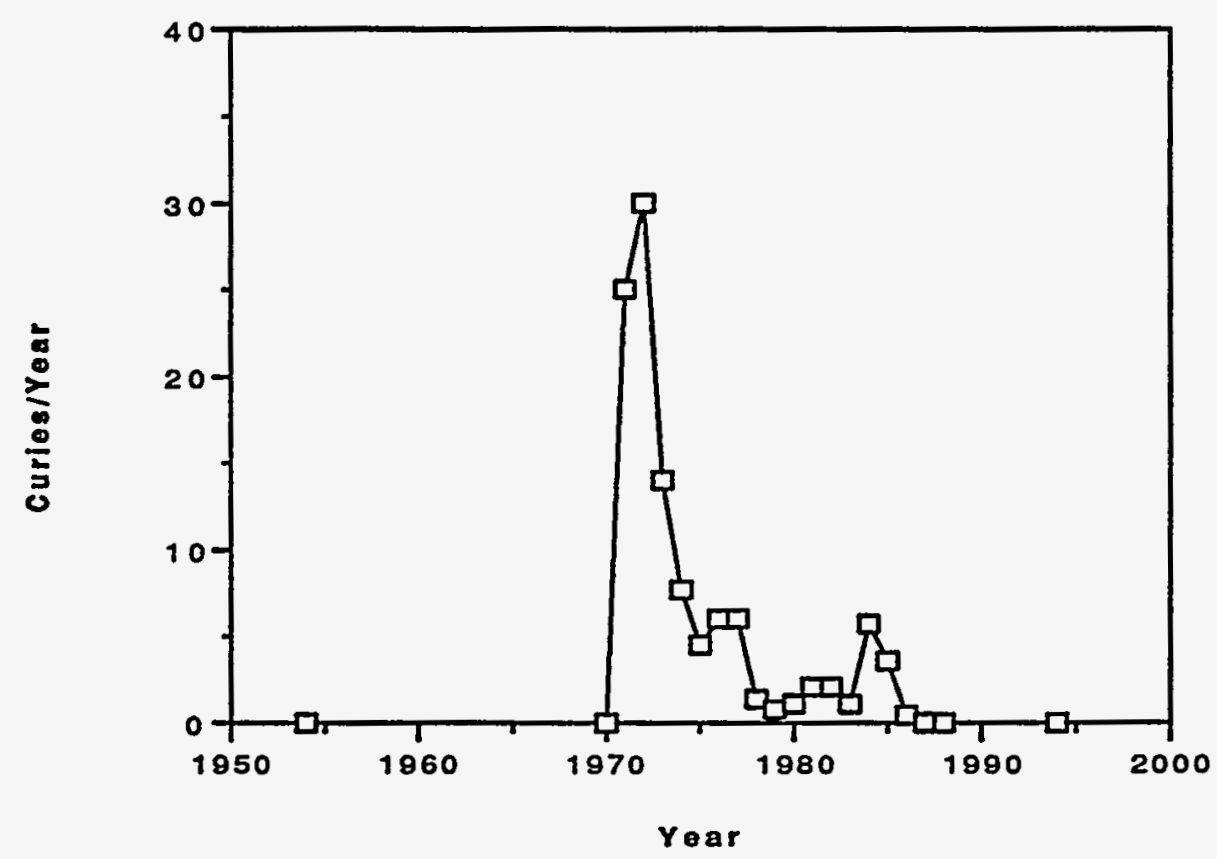

Figure 3.23. H-Area Co-60 Releases to Basins

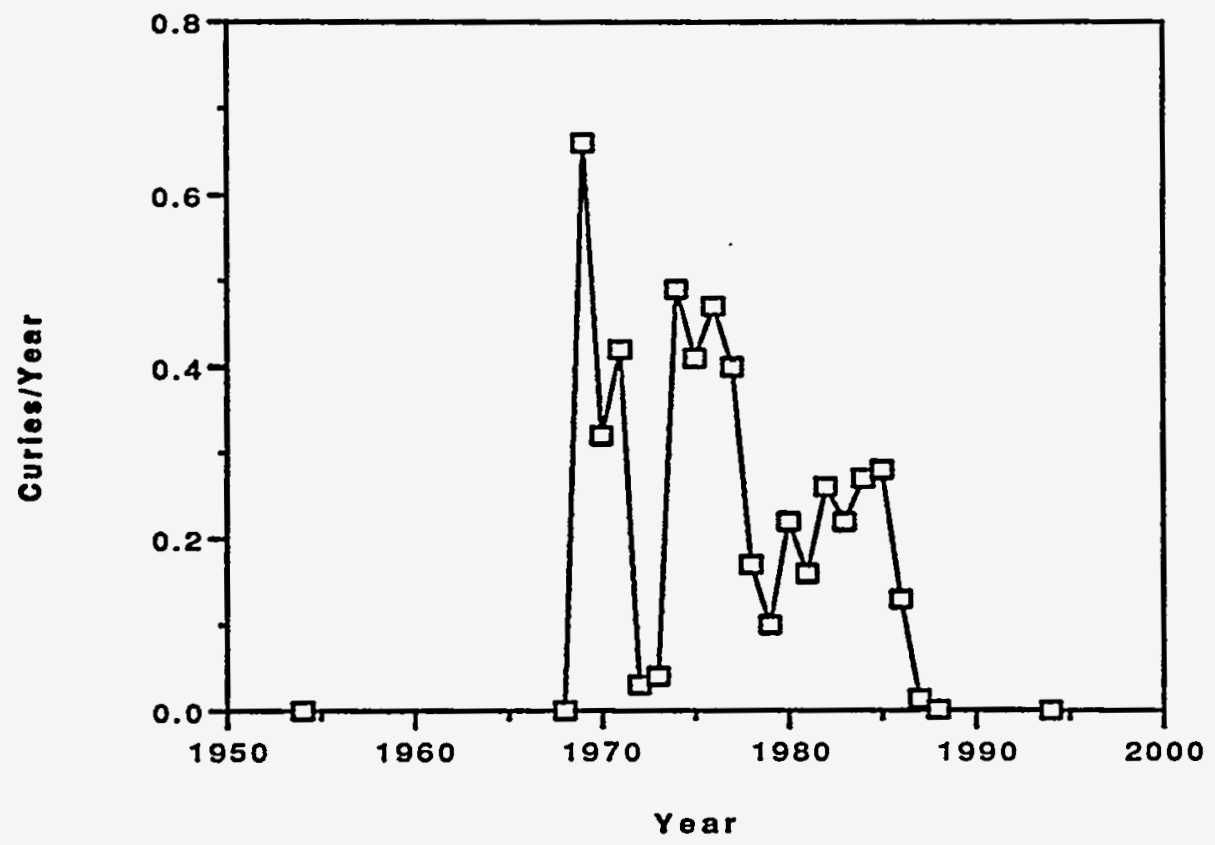

95X05039.fmk

3-25 
Figure 3.24. H-Area Zn-65 Releases to Basins

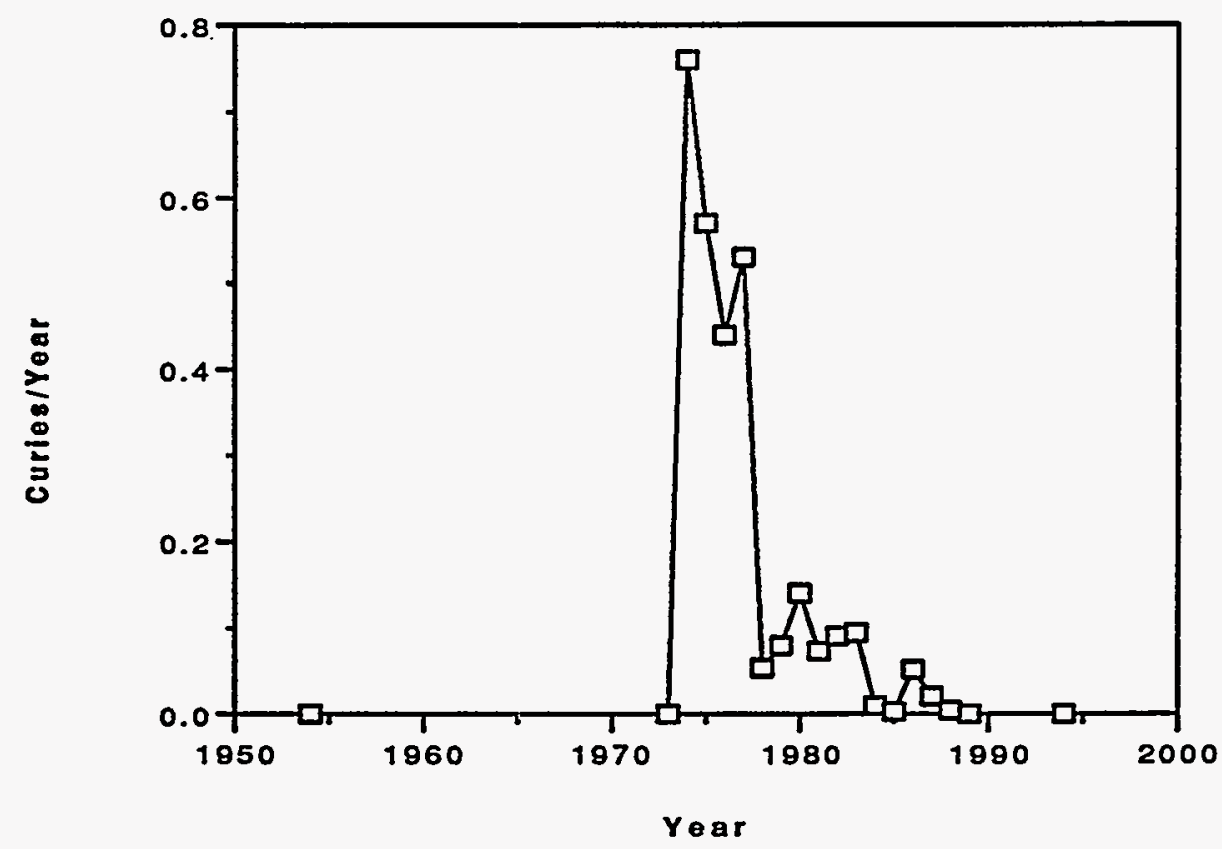

Figure 3.25. SRTC Co-60 Releases to Atmosphere

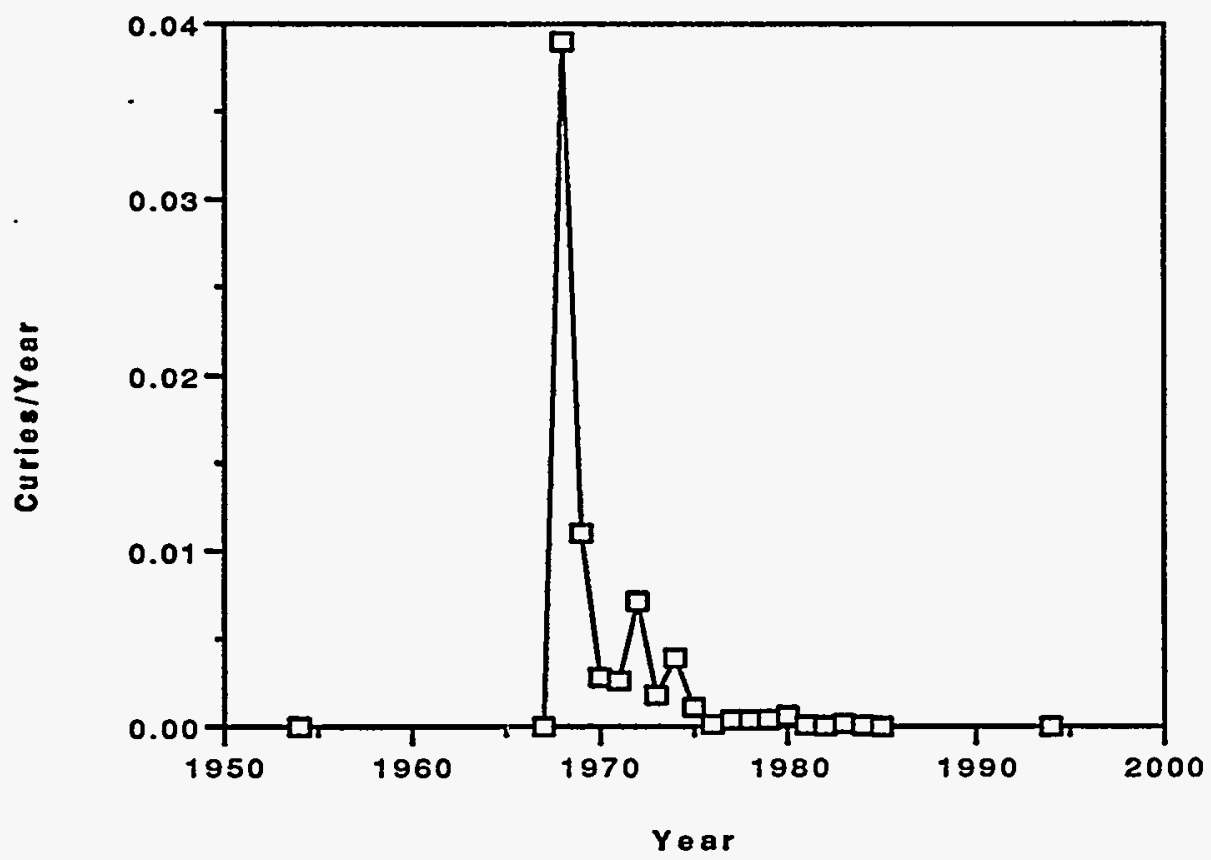




\section{Waste Tank Farms}

High-level, radioactive, liquid-waste storage tanks, located in F Area and $\mathrm{H}$ Area, are known to contain the longer-lived activation product ${ }^{60} \mathrm{Co}$, and once contained others. However, because only one reactor has operated at low power for a short time since 1988 , only ${ }^{60} \mathrm{Co}$ remains in significant quantities. Efforts are under way to quantify the remaining ${ }^{60} \mathrm{Co}$, but it is likely that less than one million curies is in the tank farms.

\section{Summary of Separations and Liquid-Waste Facilities}

Atmospheric releases totaled $1.9 \times 10^{-2} \mathrm{Ci}$ of ${ }^{60} \mathrm{Co}$, with most of the activity released in 1971. No activation products were reported released to streams. Releases to basins were reported only for $\mathrm{H}$ Area and totaled $1.1 \times 10^{2} \mathrm{Ci}$ of ${ }^{51} \mathrm{Cr}, 5.1 \times 10^{6} \mathrm{Ci}$ of ${ }^{60} \mathrm{Co}$, and $2.9 \times 10^{0} \mathrm{Ci}$ of ${ }^{65} \mathrm{Zn}$.

\section{Solid Waste Disposal Facility}

Radioactive solid wastes generated during SRS operations have been bumed in the low-level waste incinerators or buried in the SWDF. Because of the nature of much of the waste, precise analysis of the radioactive inventory of materials committed to the SWDF is not available. Estimates of the radioactive content of packaged wastes are made from radiation surveys of the packages, and conversion factors are applied based on known or assumed fission or activation product content. The data on each package are recorded at the burial facility, and a computerized inventory is maintained. Based on these data, the estimated decay-corrected ${ }^{60} \mathrm{Co}$ content of the SWDF was $3.6 \times 10^{5} \mathrm{Ci}$ as of December 31, 1987 (Hurrell et al. 1988). The quantity of other activation products was $2.9 \times 10^{5} \mathrm{Ci}$ but no distribution was given.

\section{Savannah River Technology Center}

The Savannah River Technology Center provided research and development support for the production facilities of SRS. Laboratory facilities handled radioactivity that ranged from environmental levels to highly radioactive materials-the latter manipulated in shielded cells.
Atmospheric releases of ${ }^{60} \mathrm{Co}$ were reported from 1968 to 1984. The maximum annual release was 3.9 $\times 10^{-2} \mathrm{Ci}$ in 1968 , and the total release was $7.2 \times 10^{-2}$ $\mathrm{Ci}$. The releases likely were the result of research on a thermoelectric generator program that used many thousands of curies of ${ }^{60} \mathrm{Co}$ as the heat source (Angerman 1973; Zecha 1987). Releases by year are shown in Figure 3.25 and Table 3-6.

Liquid radioactive wastes were accumulated in holding tanks pending shipment to $F$ Area for treatment and disposition.

From 1954 to 1982, a seepage basin system was used for low-activity wastes. The first two seepage basins, both designated 904-53G, were put in service in 1954. The last two, 904-54G and -55G, were added in 1958 and 1960, respectively. There is no record of activation product releases to streams or basins.

\section{Other Facilities}

A number of other facilities handled materials containing activation products. These were the test reactors, the Heavy Water Rework Facility, and any facility handling spontaneously fissioning elements.

No releases of activation products were documented for any of the test reactors described in Chapter 2. Had there been releases from these facilities, they would have been small compared to those from production reactors. Operation of these test reactors was discontinued in the 1970s.

The Heavy Water Rework Facility, located in D Area, consisted of four distillation towers and associated equipment to remove ordinary water that accumulated in the heavy water moderator used in the reactors. Leaks in the system were vented through a 21-meter stack. The aqueous waste stream was sent to Beaver Dam Creek after verification that activity levels did not exceed specific limits. The predominant radioactivity associated with this facility was tritium.

Potential existed for traces of activation products to be present in the moderator, as was described in the section on reactor facilities. A small amount $(4.3 \times$ $10^{-3} \mathrm{Ci}$ ) of ${ }^{32} \mathrm{P}$ was released to streams in 1973 . A slightly larger amount $\left(9.0 \times 10^{-2} \mathrm{Ci}\right)$ of ${ }^{51} \mathrm{Cr}$ was released in 1967. A total of $1.7 \times 10^{-1} \mathrm{Ci}$ of ${ }^{60} \mathrm{Co}$ was released during the period 1967 to 1973, and the highest year was 1967 with $1.1 \times 10^{-1} \mathrm{Ci}$ released. The annual releases are shown in Table 3-8.

Central Shops at SRS fabricates and repairs equipment used in the separations and reactor areas of the 
Site. Although equipment is decontaminated before it is sent to Central Shops, some radioactive material occasionally is present and normally is removed during cleaning before the equipment is repaired. The contamination is transferred with other liquid waste streams to a seepage basin. The yearly releases of ${ }^{60} \mathrm{Co}$ to the Central Shops Seepage Basin (Ford Basin) are shown in Table 3-8. The total ${ }^{60}$ Co release was $6.9 \times 10^{-4} \mathrm{Ci}$.

Facilities other than those already described in this chapter that handled spontaneously fissioning elements were the reactor material facilities for uranium fuel and target fabrication in MArea, the TNX Semi Works where various processes were tested on a pilot scale with uranium, and the Naval Fuels facility where uranium fuel for the U.S. Navy was fabricated during the late 1980s. The presence of low levels of activation products that are attributable to spontaneous fission had no impact on the environment and is of academic interest only.

\section{References}

Angerman, C. L., 1973, Savannah River Laboratory Cobalt60 Power and Heat Sources, Final Quarterly Progress Report, DP-1338, E.I. duPont de Nemours \& Co., Aiken, SC.

Cummins, C. L., C. S. Hetrick, and D. K. Martin, 1991, Radioactive Releases at the Savannah River Site 1954-1989, WSRC-RP-91-684, Westinghouse Savannah River Company, Aiken, SC.

Hurrell, S. J., C. D. Collier, and D. H. Walker, 1988, Safety Analysis-200-Area Savannah River Plant Burial Ground Operations, DPSTSA-200-10, Supp. 8, prepared by Science Applications International Corporation for E. I. du Pont de Nemours and Company, Aiken, SC.

Jacobsen, W. R., W. L. Marter, D. A. Orth, and C. P. Ross, 1973, Control and Treatment of Radioactive Liquid Waste Effluents at the Savannah River Plant, DP-1349, E. I. du Pont de Nemours and Company, Aiken, SC.

Taylor, R. W., 1989, Effluent Treatment Facility Emissions Monitoring, DPST-89-309, E. I. du Pont de Nemours and Company, Aiken, SC.

Zecha, D. J., $1987,{ }^{60}$ Co Fueled Thermoelectric Generator Burial, DPSOX-10051, E.I. duPont de Nemours \& Co., Aiken, SC. 
Table 3-8. Miscellaneous Releases

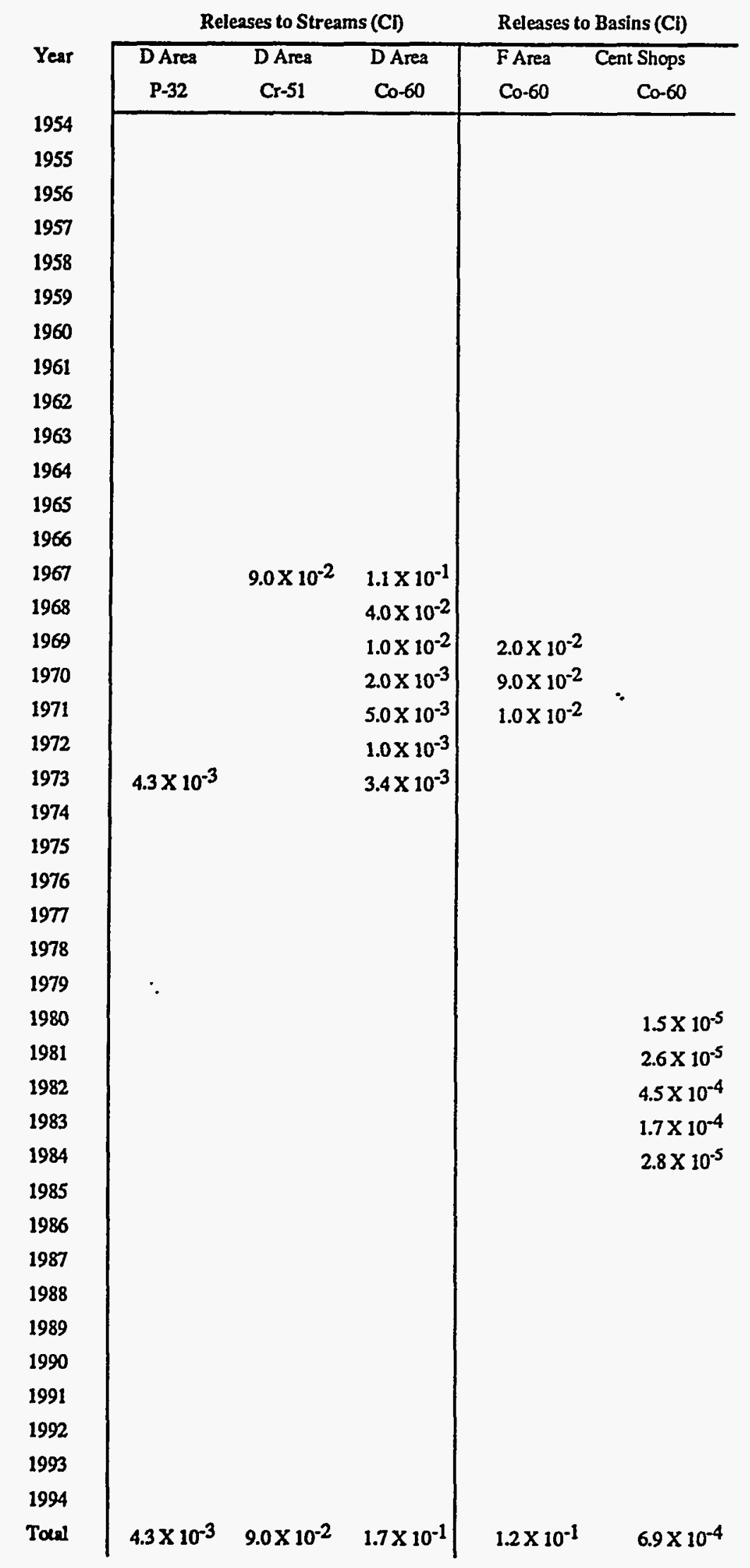




\section{Chapter 4. Activation Products Concentration and Transport Mechanisms}

Activation products released to the environment may be transported in the atmosphere, surface waters, andlor groundwater below SRS. This chapter presents a description of the physical features and details of transport mechanisms for surface waters and groundwater. 
This page intentionally left blank 


\section{Atmospheric Transport}

There were no recorded atmospheric releases of ${ }^{32} \mathrm{P}$, ${ }^{51} \mathrm{Cr}$, and ${ }^{65} \mathrm{Zn}$. Atmospheric releases of ${ }^{60} \mathrm{Co}$ occurred from 1968 through 1984 in A Area, in each of four years in F Area, and in each of two years in $\mathrm{H}$ Area. The largest annual release, $3.9 \times 10^{-2} \mathrm{Ci}$, occurred in A Area in 1968. No other annual release was even half as large. These releases are too small to be measurable in the environment and will be included in the Chapter 5 dose modeling.

\section{Aqueous Transport}

\section{Surface Waters on the Savannah River Site}

Activation products transported by SRS surface waters originated from three sources; fallout, atmospheric releases from SRS operations, and direct releases to streams. Fallout was deposited on the Savannah River watershed as a result of atmospheric testing of nuclear weapons. Fallout radioactivity was deposited uniformly across the Site, except in cases of rainout, when locally heavy deposits were found (Marter 1986). The quantity of activation products was quite small compared with fission products. Atmospheric activation product releases from SRS operations have been small in comparison with stream releases. Direct releases to streams have been reported in Cummins (1991) and are summarized in Table 4-1.

Table 4-1. Releases to Streams by Area

\begin{tabular}{ccccc}
\multicolumn{5}{c}{ Radioactivity (Ci) } \\
\hline Area & P.-32 & Cr-51 & Co-60 & Zn-65 \\
\hline C & $4.4 \times 10^{0}$ & $1.4 \times 10^{3}$ & $1.2 \times 10^{1}$ & $2.8 \times 10^{1}$ \\
K & $2.1 \times 10^{1}$ & $8.8 \times 10^{2}$ & $1.7 \times 10^{1}$ & $1.9 \times 10^{1}$ \\
L & $3.7 \times 10^{0}$ & $7.4 \times 10^{2}$ & $1.5 \times 10^{1}$ & $2.5 \times 10^{1}$ \\
P & $6.9 \times 10^{0}$ & $8.8 \times 10^{2}$ & $1.2 \times 10^{1}$ & $3.2 \times 10^{1}$ \\
R & $6.2 \times 10^{-1}$ & $5.5 \times 10^{2}$ & $1.1 \times 10^{1}$ & $3.8 \times 10^{1}$ \\
H & & $1.1 \times 10^{2}$ & $5.1 \times 10^{0}$ & $2.9 \times 10^{0}$ \\
D & $4.3 \times 10^{-3}$ & $9.0 \times 10^{-2}$ & $1.7 \times 10^{-1}$ & \\
Total & $3.7 \times 10^{1}$ & $4.6 \times 10^{3}$ & $7.2 \times 10^{1}$ & $1.4 \times 10^{2}$ \\
\hline
\end{tabular}

Several streams have received cooling water from reactors and process water from separations facilities with most of the liquid releases occurring in the reactor areas. Most of the activation products entering the streams was transported directly to the Savannah River, although some ${ }^{60} \mathrm{Co}$ was deposited in stream beds, floodplains, and ponds (Gladden et al. 1985).

\section{Lower Three Runs Creek}

Lower Three Runs Creek has the second largest drainage area of SRS streams. Both P Reactor and R Reactor have discharged effluents to the Lower Three Runs system. At SRS, a large (2600-acre) impoundment, PAR Pond, was constructed in 1958 to provide recirculating cooling water through $P$ Reactor and $R$ Reactor. Several smaller ponds were built between the reactors and PAR Pond to provide additional cooling for reactor cooling water before it entered PAR Pond. The average natural flow rate of Lower Three Runs Creek at the PAR Pond dam is $1 \mathrm{~m}^{3} / \mathrm{sec}$. From the PAR Pond dam, the creek flows 38 kilometers to the Savannah River.

\section{Upper Three Runs Creek}

Upper Three Runs Creek is the largest on the Site, with a watershed of $540 \mathrm{~km}^{2}$, a natural flow rate of $7 \mathrm{~m}^{3} / \mathrm{sec}$, and a length of $40 \mathrm{~km}$. Effluents are received from $M$ Area and SRTC, and since 1988, the ETF in H Area has been releasing treated water.

\section{Steel Creek}

Steel Creek is $18 \mathrm{~km}$ long and has a watershed of 90 $\mathrm{km}^{2}$. The natural flow rate is $1 \mathrm{~m}^{3} / \mathrm{sec}$, but was as high as $22 \mathrm{~m}^{3} / \mathrm{sec}$ when both $P$ Reactor and $\mathrm{L}$ Reactor discharged cooling water to the creek in the early $1960 \mathrm{~s}$. PReactor cooling water was diverted to PAR Pond in 1964, and L Reactor was shut down in 1968, then restarted in 1985 . P- Reactor disassembly basin water continued to flow to Steel Creek. L Lake was built in 1985 to provide cooling for L- Reactor discharges. Steel Creek travels about $3 \mathrm{~km}$ through a swamp before entering the Savannah River (Murphy 1991).

\section{Fourmile Branch}

Fourmile Branch has a watershed of $57 \mathrm{~km}^{2}$, is approximately $24 \mathrm{~km}$ long, and has a natural flow of $0.14 \mathrm{~m}^{3}$ / sec. It receives effluent from $F$ Area and $H$ Area and received cooling water from C Reactor until 1985. 


\section{Pen Branch}

Pen Branch has a watershed of $55 \mathrm{~km}^{2}$, is approximately $24 \mathrm{~km}$ long, and has a natural flow of $0.2 \mathrm{~m}^{3}$ / sec. Once it reaches the Savannah River Swamp, the flow path becomes relatively undefined through the swamp parallel to the Savannah River for about $8 \mathrm{~km}$ before entering Steel Creek. Pen Branch receives cooling water from $\mathrm{K}$ Reactor.

\section{Site Stream Summary}

The total historical releases to streams is $3.7 \times 10^{1} \mathrm{Ci}$ of ${ }^{32} \mathrm{P}, 4.6 \times 10^{3} \mathrm{Ci}$ of ${ }^{51} \mathrm{Cr}, 7.2 \times 10^{1} \mathrm{Ci}$ of ${ }^{60} \mathrm{Co}$, and $1.4 \times 10^{2} \mathrm{Ci}$ of ${ }^{65} \mathrm{Zn}$. The breakdown of releases by area is shown in Table 4-1. Analysis of site stream sediments indicates levels of ${ }^{60} \mathrm{Co}$ greater than upriver samples for Fourmile Branch, Pen Branch, and Steel Creek. Cobalt- 60 activity levels in sediment samples from Upper Three Runs and Lower Three Runs were indistinguishable from offsite locations (Gladden et al. 1985).

\section{Savannah River}

The Savannah River forms most of the border between Georgia and South Carolina and drains approximately $25,900 \mathrm{~km}^{2}$ in eastern Georgia and western South Carolina. The flow rate averages about $285 \mathrm{~m}^{3} / \mathrm{sec}$ at Augusta and increases to $340 \mathrm{~m}^{3} / \mathrm{sec}$ downriver near Clyo, Georgia. Water from the river is used at two water treatment plants, Beaufort-Jasper and Port Wentworth. Sediment samples collected upriver of SRS and downriver near the U. S. Highway 301 bridge did not have significantly different levels of ${ }^{60} \mathrm{Co}$ (Gladden 1985).

\section{Groundwater Concentra- tions and Transport}

\section{SRS Groundwater System}

The Savannah River Site lies on the Atlantic Coastal Plain, about $32 \mathrm{~km}$ southeast of the edge of the Piedmont Physiographic Province. The Coastal Plain is underlain by a seaward-dipping wedge of sediments that thins to the northwest where it contacts the exposed crystalline rocks of the Piedmont (Figure 4.1). The sediments of interest in this report are those of Cretaceous or younger age that contain the aquifers that supply much of the drinking water for the area surrounding SRS. These sediments were deposited in shallow marine to fluvial environments (Gohn 1988) and consist of interbedded sands and clays with minor occurrences of calcareous rocks.

The stratigraphic names applied to the various units have been modified as more detailed information has become available. Figure 4.2 compares some of the changes that have occurred in the hydrostratigraphic nomenclature since the mid 1960s. The current nomenclature (Aadland et al. 1992) takes into account the progressive thickening of the aquifers across the Site and the effectiveness of the confining units that separate the aquifer units. The recent changes avoid tying the aquifer nomenclature to the lithostratigraphic names and extend existing hydrostratigraphic nomenclature from surrounding regions into SRS. A map view, Figure 4.3, shows the approximate limits of the Coastal Plain aquifer systems across SRS.

At the base of the Coastal Plain sediments is an aquitard, the Appleton Confining System, composed of residual soils of the basement rocks and dense clays of the Cape Fear Formation. Overlying this confining unit are two aquifers in Cretaceous sands, McQueen Branch and Crouch Branch. Generally, these sands are considered to be prolific water producers and are the source for most of the water supply wells on the Site. They are separated from each other by the relatively less permeable beds that make up the Black Creek Formation.

The Tertiary aquifers are separated from the underlying Cretaceous aquifer units by confining beds of the Black Mingo Group, especially the Ellenton Formation. On the northwestern corner of the Site, the separation is not as effective as in the southem portion.

In the southeastern area, the Tertiary section can be divided into two separate aquifers, the Gordon (formerly called the "Congaree Aquifer") and Upper Three Runs (frequently referred to as the "Bamwell Aquifer" or "Watertable Aquifer"). The aquitard or confining bed that separates these two units is a glauconitic clayey zone of the McBean Formation locally referred to as the "green clay." This clay pinches out and becomes more sandy toward the northwest.

In some areas of the Site, it is necessary to modify the hydrostratigraphic nomenclature because of local changes in lithologies and topography. For example, in some portions of the Site, an aquitard unit referred to as "tan clay" subdivides the uppermost aquifer into two separate zones. In the southern portion of the 


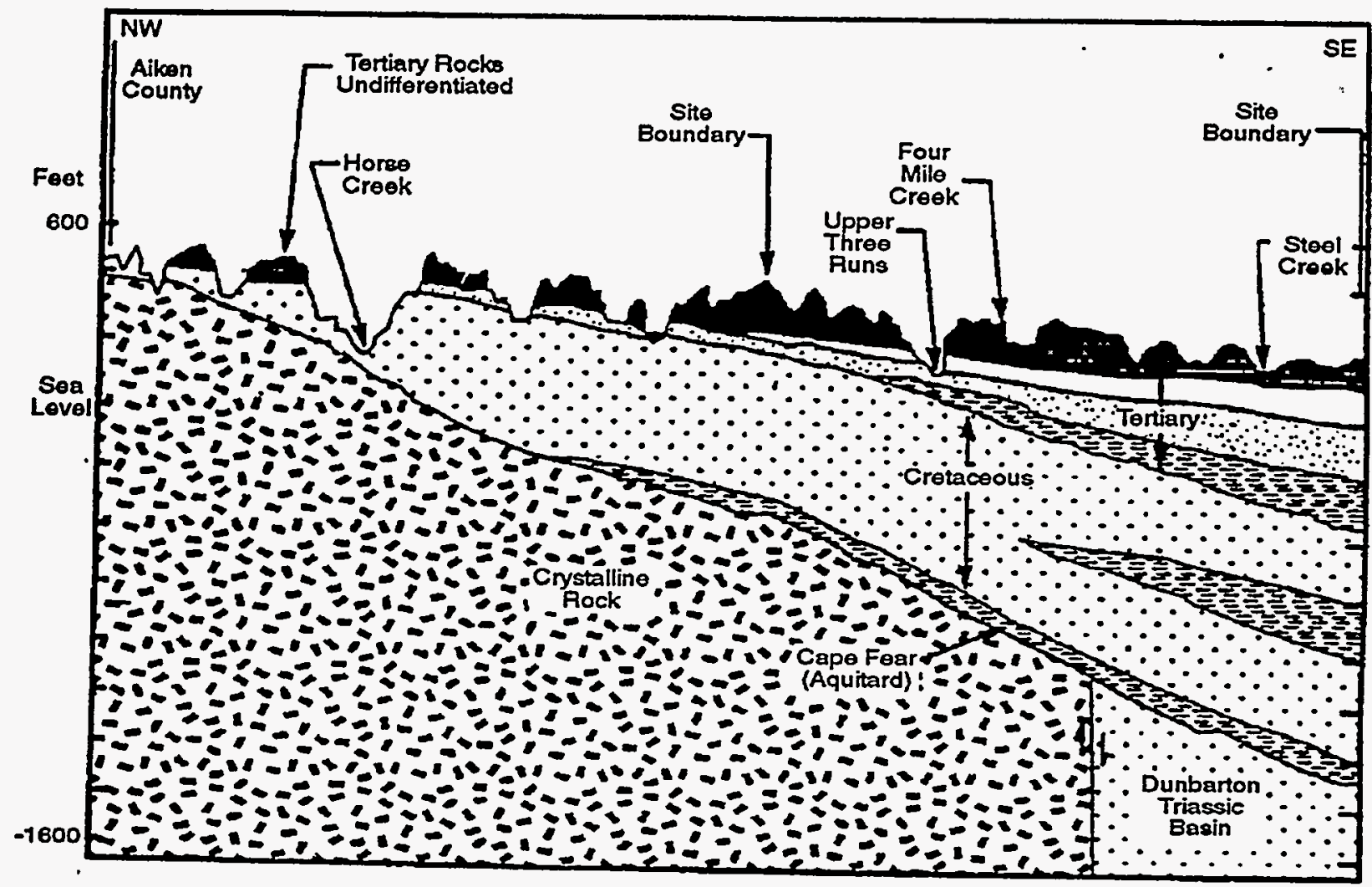

Figure 4.1. Geological Cross Section Showing the Main Aquifers

\begin{tabular}{|c|c|c|c|c|c|c|}
\hline & 1967 & 1967 & \multicolumn{3}{|c|}{1990} & 1989 \\
\hline \multirow{7}{*}{ 呇 } & Hawthom Aquifer & \multirow{5}{*}{$\begin{array}{l}\text { Tertiary } \\
\text { Sand } \\
\text { Aquiler }\end{array}$} & \multicolumn{3}{|c|}{ Upland Unit } & \multirow{2}{*}{$\begin{array}{l}\text { Upland Univ } \\
\text { Hawthom }\end{array}$} \\
\hline & Bamwell & & 善 害 & \multicolumn{2}{|c|}{ Tobacco Rd Formation } & \\
\hline & McBean Aquifor & & $\begin{array}{l}\text { 을 } \\
\text { 은 } \\
\text { o }\end{array}$ & $\begin{array}{l}\text { Dry Branch } \\
\text { Formetion }\end{array}$ & $\begin{array}{l}\text { Cinctriedd Sand Mbr } \\
\text { Grifins Lending Mbr } \\
\text { rwinton Sand Mbr } \\
\text { Twiggs Clay Mbr }\end{array}$ & Barmwell \\
\hline & \multirow[t]{2}{*}{ Congaree Aquifer } & & 离 & \multicolumn{2}{|c|}{$\begin{array}{l}\text { McBean Formation } \\
\text { Green Clay }\end{array}$} & Mobean $\sum$ Sarioo \\
\hline & & & $\delta$ & \multicolumn{2}{|c|}{ Congaree Formation } & Congareo Wartoy \\
\hline & \multirow{2}{*}{$\begin{array}{l}\text { Ellenton } \\
\text { Aquitard }\end{array}$} & \multirow{2}{*}{$\begin{array}{l}\text { Confining } \\
\text { Unit }\end{array}$} & \multirow{2}{*}{ 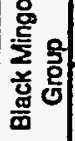 } & \multicolumn{2}{|c|}{ Williansburg Formation } & Black Mingo \\
\hline & & & & \multicolumn{2}{|c|}{ Ellenton Formation } & Ellenton Formation \\
\hline \multirow{4}{*}{ 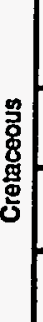 } & $\begin{array}{c}\text { Upper Tuscaloos } \\
\text { Aquifer }\end{array}$ & $\begin{array}{c}\text { Black Creek } \\
\text { Aquifer }\end{array}$ & \multirow{3}{*}{ 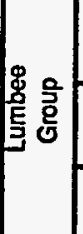 } & \multicolumn{2}{|c|}{ Peodee Formation } & Peedee Formation \\
\hline & $\begin{array}{l}\text { Mid Tuscaloosa } \\
\text { Clay Aquitard }\end{array}$ & $\begin{array}{l}\text { Confining } \\
\text { Unit }\end{array}$ & & \multicolumn{2}{|c|}{ Black Creek Formation } & Black Creek Formatio \\
\hline & $\begin{array}{c}\text { Lower Tuscaloosa } \\
\text { Aquiler }\end{array}$ & $\begin{array}{l}\text { Middendorf } \\
\text { Formation }\end{array}$ & & \multicolumn{2}{|c|}{ Middendorf Formation } & Middendorf Formation \\
\hline & $\begin{array}{l}\text { Basal Clay } \\
\text { Aquitard }\end{array}$ & $\begin{array}{l}\text { Confining } \\
\text { Unit }\end{array}$ & & \multicolumn{2}{|c|}{ Cape Fear Formation } & Cape Fear Formation \\
\hline
\end{tabular}

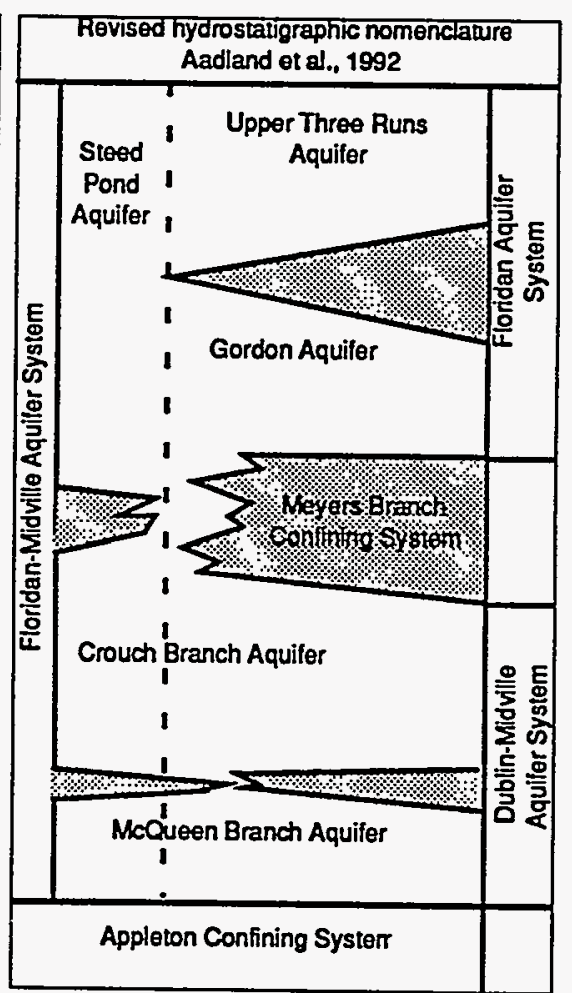

Figure 4.2. Stratigraphic and Hydrostratigraphic Nomenclature Used at SRS 


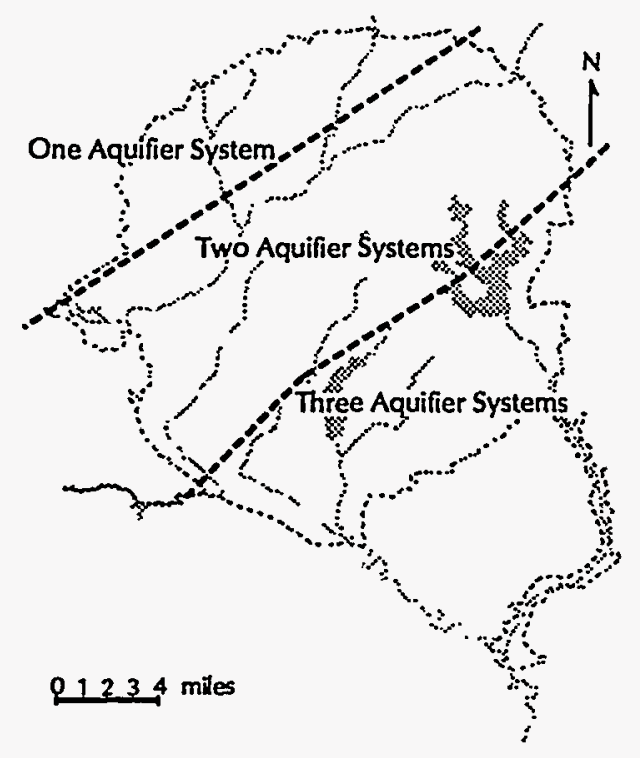

Figure 4.3. Updip Limits of the Confining Systems in the Coastal Plains Sediments

Site, the "tan clay" unit is thin or sporadic and does not form a consistent aquitard.

The water table level is controlled primarily by local topographic features. The surface of the Atlantic Coastal Plain at the Site is a relatively flat plateau (the Aiken Plateau) dissected by stream erosion. The incision of the streams has left relatively isolated, flatlying surfaces separated by 27- to 38-m-deep stream valleys. The depth to the water table below land surface varies from $0 \mathrm{~m}$, when it outcrops in the stream valleys or wetlands, to $38 \mathrm{~m}$ below the remnant plateau areas. The water table depth usually is controlled by the elevation of the nearest Savannah River tributary stream. At many localities onsite, the water table is situated in Tertiary sediments of low water-producing capabilities, and perched water tables exist sporadically across the Site:

The direction of groundwater flow at any locality may change or even reverse in successively deeper aquifers. The aquifers in the Tertiary sediments receive local recharge, and flow generally is toward nearby stream valleys. Typically, flow at the water table is toward minor tributaries, while deeper Tertiary aquifers flow toward major tributaries of the Savannah River. The deepest aquifers at SRS, the Dublin-Midville Aquifer System, receive recharge in the outcrop areas of the Cretaceous sediments north of the Site. Groundwater flow beneath the Site in this system is toward the Savannah River.

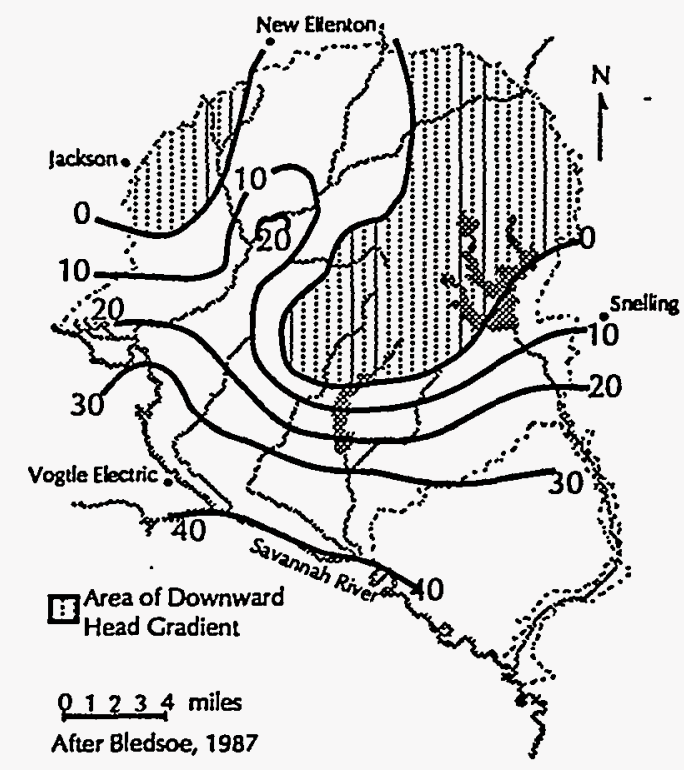

Figure 4.4. Hydraulic Head Differences Across Confining Units Near the Cretaceous/Tertiary Boundary

Over much of the Site, the potentiometric surface, or hydraulic "head," of the deeper aquifers in the Cretaceous sediments is higher than that of the overlying Tertiary aquifers (Christensen and Gordon 1983). This upward gradient, an important characteristic of many of the waste disposal areas, has provided protection from downward transport of contaminants to the deeper aquifers on the Site. Figure 4.4 outlines the areas where there is an upward hydraulic gradient across the confining units near the Cretaceous-Tertiary boundary.

\section{Activation Products in SRS Groundwater}

Elevated concentrations of short-lived radionuclides cannot be maintained over long migration distances in groundwater because groundwater moves slowly. Typical groundwater velocities are on the order of meters to tens of meters per year. Thus, ${ }^{32} \mathrm{P}$ and ${ }^{51} \mathrm{Cr}$, with half-lives of 14 and 28 days, can only travel several meters in groundwater before decaying to negligible concentrations. Though ${ }^{65} \mathrm{Zn}$ (half-life of 244 days) can travel farther, there are no consistently elevated concentrations in groundwater sampled by monitoring wells at SRS. Consistently elevated groundwater concentrations of the longer lived ${ }^{60} \mathrm{Co}$ (half-life 5.3 years) occur at one location. 


\section{Cobalt-60 Chemistry in Groundwater}

The chemistry of cobalt is similar to that of iron. Like iron, dissolved cobalt can exist in Co(II) and Co(III) oxidation states. However, $\mathrm{Co}$ (III) is only dominant at conditions beyond the oxidation limits of water at $25^{\circ} \mathrm{C}$ and 1 atmosphere, and thus in groundwater $\mathrm{Co}$ (II) is the dominant form. Under groundwater conditions typical of SRS, the $\mathrm{Co}^{+2}$ form of cobalt is dominant. Above a $\mathrm{pH}$ of 7.5, complexes resulting from hydrolysis are dominant.

In the acidic conditions that are common in SRS groundwaters and waste streams, cobalt is relatively mobile. Solubility controls on the migration of cobalt in groundwater can be exerted by carbonate and phosphate phases; but in SRS groundwater, cobalt concentrations generally are below saturation with these phases. Co-precipitation can exert controls on the migration of cobalt, if iron or manganese phases are precipitating within the contaminant plume. Similarly, somtion to aquifer solids can attenuate cobalt migration. Factors such as $\mathrm{pH}$, mineralogy, and grain size strongly influence sorption. This is reflected in the range of $K_{d}$ values (the ratio of the amount of a constituent sorbed to the solid phase over the concentration in water at equilibrium), 0.2 to $3800 \mathrm{ml} / \mathrm{g}$, found in a literature survey by Baes et al. (1984).

From 1954 through 1988, seepage basins were used at SRS to dispose of wastewater containing low concentrations of chemicals and radionuclides. The seepage basins were intended to delay the release of radionu- clides that could not otherwise be contained and to allow time for radioactive decay to decrease the activity (Reichert 1968). Several of these basins were located near F Aréa and H Area (see Figure 4.5). Groundwater sampled by monitoring wells in the vicinity of the HArea seepage basins contains consistently elevated concentrations of ${ }^{60} \mathrm{Co}$.

The four H-Area seepage basins, covering an area of $42,700 \mathrm{~m}^{2}$, were in use from 1955 to 1988 . Liquids discharged to these basins contained low-level radioactivity from the H-Area separations facility. In addition, the effluents to these basins contained heavy metals, nitrate in the form of $\mathrm{HNO}_{3}$, and $\mathrm{NaOH}$ (Killian et al. 1985). The basins were closed in 1988 and since have been capped.

The depth of the water table is only about $6 \mathrm{~m}$, and the basins are located close to the groundwater discharge zone along Fourmile Branch. Much of the groundwater flow in this area of the Site appears to occur in narrow, high-permeability channels in the sediments. While a small percentage of the seepage basin waters penetrates into a deeper aquifer, the majority of the waters migrate to the seepline adjacent to Fourmile Branch.

Groundwater sampled by monitoring wells down gradient from the H-Area seepage basins contains elevated ${ }^{60} \mathrm{Co}$ activity. The activity in most wells is either below detection limits or slightly elevated. In five water table wells, the activity has been consistently above the EPA drinking water standard $(100 \mathrm{pCi} / 1)$. However, Figure 4.6 shows that the ${ }^{60} \mathrm{Co}$ activity in these wells has decreased with time.

Figure 4.5. Location Map of Waste Disposal Sites near F Area and H Area

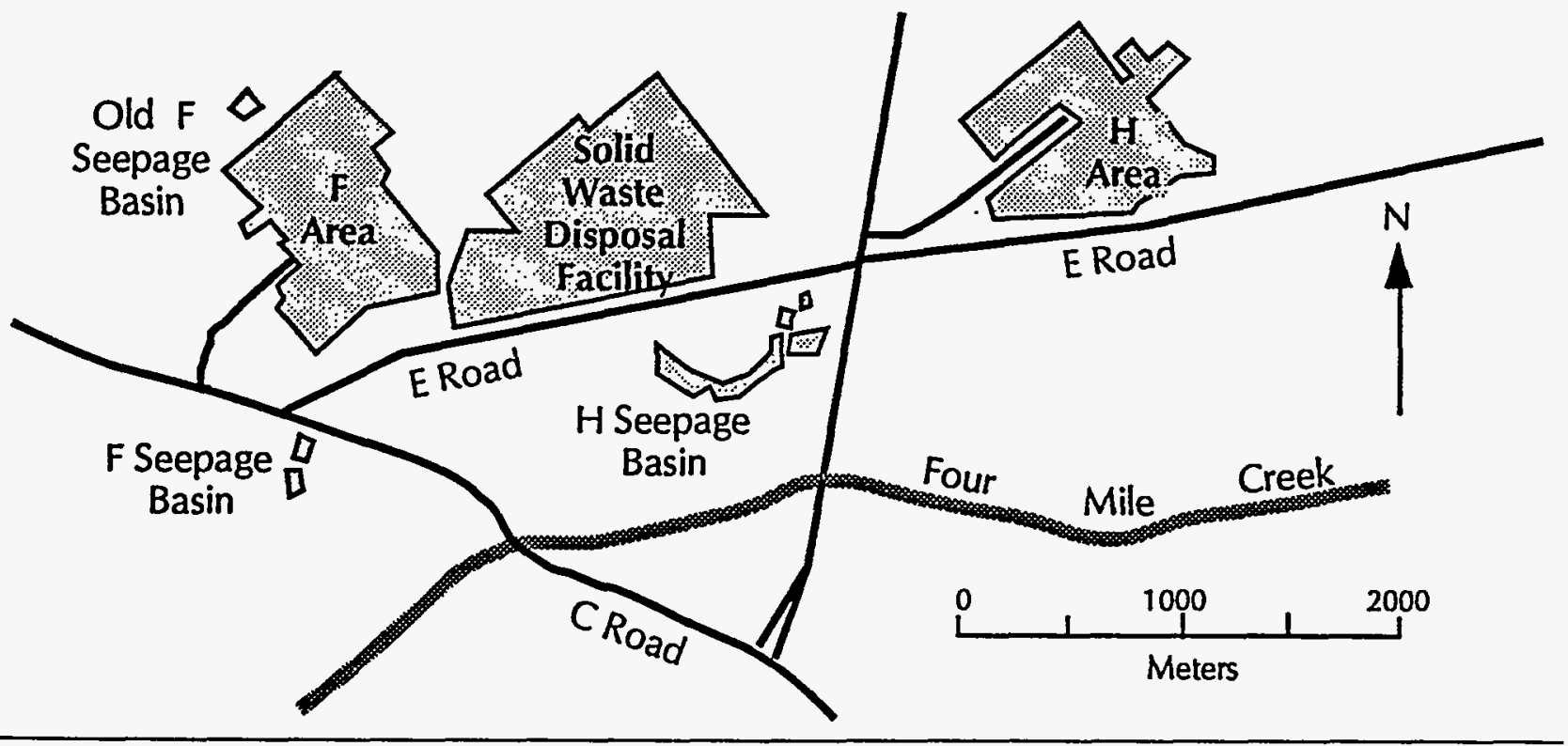



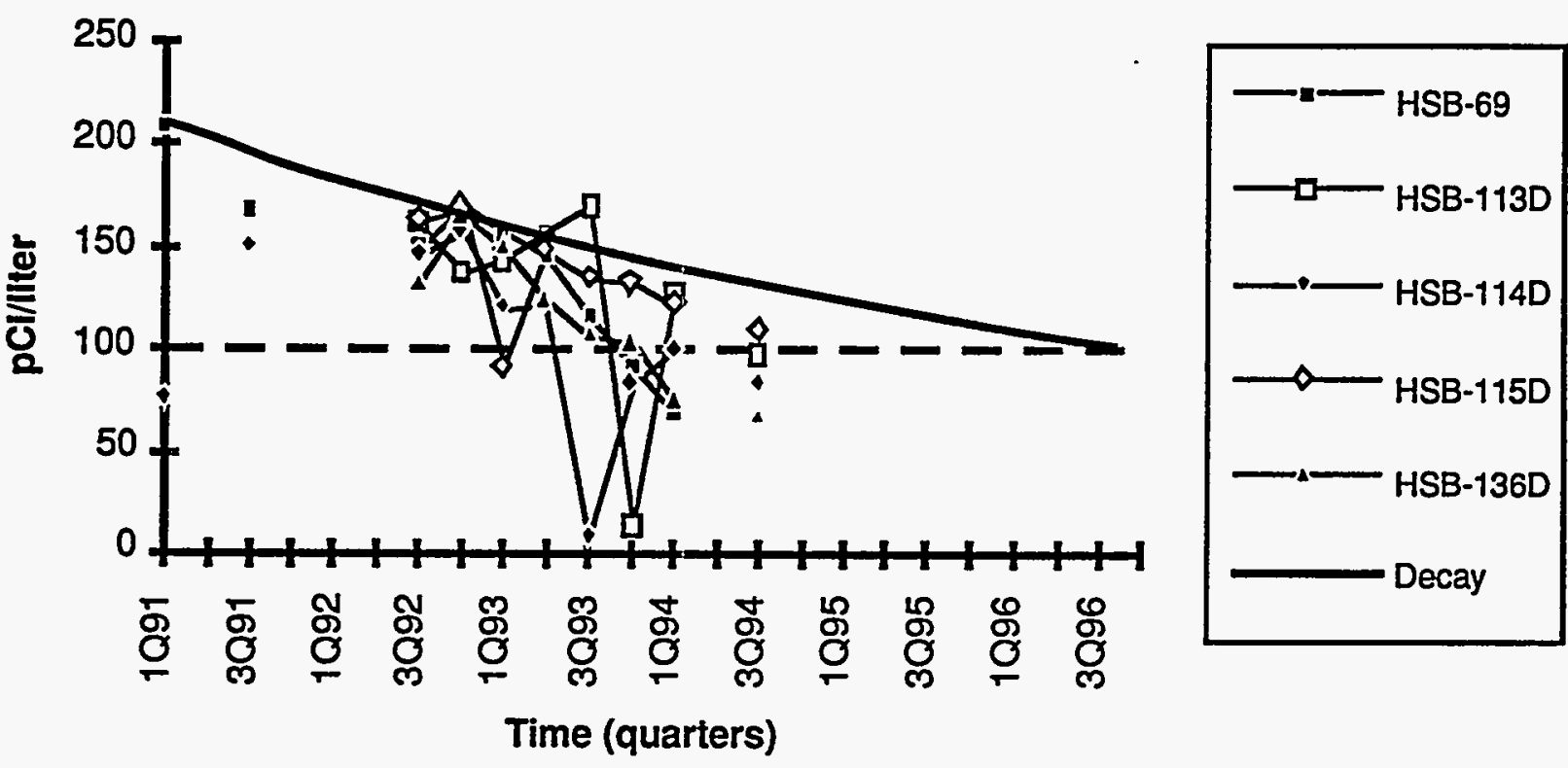

Figure 4.6 Time Series Plot Showing ${ }^{60} \mathrm{Co}$ Activities in Groundwater from the Five Wells that have Exceeded the Drinking Water Standard. The Heavy Solid Line is the Decay Curve of $60 \mathrm{Co}$ from the Maximum Activity of $210 \mathrm{pCi} /$ liter; the Dashed Line is the Drinking Water Standard of $100 \mathrm{pCi} /$ liter.

There is evidence that small amounts of ${ }^{60} \mathrm{Co}$ have reached the groundwater seepline along Fourmile Branch. It has been reported that one water sample from along the seepline near F Area contained elevated ${ }^{60}$ Co activity (Haslow et al. 1990). The location was sampled in 1992, 1993, and 1994, and ${ }^{60}$ Co activity was below detection limits (Dixon and Rogers 1993). However, annual samples from one location along the seepline near $\mathrm{H}$ Area indicated elevated ${ }^{60}$ Co activity, which decreased from 64.4 to 52.9 to $10.1 \mathrm{pCi} / \mathrm{l}$ from 1992 through 1994.

\section{Summary}

Short-lived activation products can travel only short distances in groundwater because of the slow velocity of the groundwater. Phosphorus-32 and ${ }^{51} \mathrm{Cr}$ are not able to migrate in groundwater from waste sites to exposure points. Though ${ }^{65} \mathrm{Zn}$ is longer lived, it has not been detected consistently in SRS groundwater. Elevated ${ }^{60} \mathrm{Co}$ activity does occur in groundwater sampled by monitoring wells associated with the $\mathrm{H}$ Area seepage basins and has been detected at low activity along the Fourmile Branch seepline. The ${ }^{60} \mathrm{Co}$ activity at all of these locations has been decreasing.

\section{References}

Aadland, R. K., P. A. Thayer, and A. D. Smits, 1992 , "Hydrostratigraphic of the Savannah River Site Region, South Carolina and Georgia", in Wallace Fallaw and Van Price, eds: Geological Investigations of the Central Savannah River Area, South Carolina and Georgia, Carolina Geological Field Trip Guide Book, Nov. 13-15, 1992, South Carolina Geological Survey, Harbison Forest Road, Columbia, SC. pp. CSG-B$\mathrm{X}-1$ to 6 .

Baes, C. F. III, R. D. Sharp, A. L. Sjoreen, and R. W. Shor, 1984, A Review and Analysis of Parameters for Assessing Transport of Environmentally Released Radionuclides through Agriculture, ORNL-5786, Oak Ridge National Laboratory, Oak Ridge, TN.

Christensen, E. J., and D. E. Gordon, 1983, Technical Summary of Groundwater Quality Protection Program at Savannah River Plant, Volume 1, DPST-83829, E. I. du Pont de Nemours \& Company, Savannah River Laboratory, Aiken, SC.

Cummins, C. L., C. S. Hetrick, and D. K. Martin, 1991, Radioactive Releases at the Savannah River Site 1954-1989 (U), WSRC-RP-91-684, Westinghouse Savannah River Company, Aiken, SC. 
Dixon, K. L., and V. A. Rogers, 1993, Semi-annual Sampling of Four Mile Creek and Its Seeplines in the $F$ - and H-Areas of SRS, WSRC-TR-93-289, Westinghouse Savannah River Company, Aiken, SC.

Gladden, J. B., M. W. Lower, H. E. Mackey, W. L. Specht, and E. W. Wilde, 1985, Comprehensive Cooling Water Study Annual Report, Volume IV, Radionuclide and Heavy Metal Transport, DP-1697-4, E. I. du Pont de Nemours \& Company, Savannah River Laboratory, Aiken, SC.

Gohn, G. S., 1988, "Late Mesozoic and Early Cenozoic Geology of the Atlantic Coastal Plains; North Carolina to Florida," The Geology of North America, Boulder, Colo., Geologic Society of America, pp 107130.

Haselow, J. S., M. Harris, B. B. Looney, N. V. Halverson, and J. B. Gladden, 1990, Analysis of Soil and Water at the Four Mile Creek Seepline Near the F\&H Areas of SRS (U), WSRC-RP-90-0591, Westinghouse Savannah River Company, Aiken, SC.
Killian, T. H., N. L. Kolb, P. Corbo, and I. W. Marine, 1985, Environmental Information Document - H Area Seepage Basins, DPST-85-706, E.I. du Pont de Nemours \& Company, Savannah River Laboratory, Aiken, $\mathrm{SC}$.

Marter, W. L., 1986, “Comments on 'Analysis of External Gamma Radiation Data around the Savannah River Plant'" Health Physics 50:652-655.

Murphy, C. E. Jr., L. R. Bauer, D. W. Hayes, W. L. Marter, C. C. Zeigler, D. E. Stephenson, D. D. Hoel, and D. M. Hamby, 1991, Tritium in the Savannah River Site Environment, WSRC-RP-90-424-1, Revision 1, Westinghouse Savannah River Company, Aiken, SC.

Reichert, S. O., 1968, "Geology Plays an Important Role in Radioactive Waste Management", Mining Engineering September, 1968: 98-103. 


\section{Chapter 5. Assessment of Dose/Risk from SRS Activation Product Releases}

This chapter describes the health impacts associated with exposure to activation products. The methodology used to produce dose estimates is presented. The results of a dose assessment for activation product releases from 1954 through 1994 are discussed. 
This page intentionally left blank. 


\section{Relationship of Dose to Risk and Health Effects}

\section{Ionizing Radiation}

Ionizing radiation is radiation that has enough energy to remove electrons from the atoms through which it passes. The interaction of ionizing radiation with biological systems can induce a series of chemical reactions that can cause permanent changes in the genetic material of cells. These changes (mutations) may cause abnormal functioning within the cell or may lead to cell death.

The nature of radiation-induced cellular changes depends on the magnitude of the dose and the rate at which it is received. For the low doses and dose rates encountered in the environment from SRS releases, the most significant potential effect is cancer induction.

This is believed to be a stochastic effect (i. e., an increase in dose increases the probability of the effect, but the severity of the effect is independent of the dose).

A characteristic of stochastic risks is the absence of a threshold. In other words, it is conceivable that any dose of radiation, no matter how small, might give rise to a cancer. On the other hand, there is no way to be certain that a given dose, no matter how large, will cause a cancer in an individual.

\section{Cancer Risk Estimates}

The most comprehensive estimates of cancer induction by exposure to ionizing radiation come from studies of the atomic bomb survivors at Hiroshima and Nagasaki. Less definitive studies include those of medical patients exposed to therapeutic and diagnostic radiation. Studies of laboratory animals have increased the understanding of dose-effect relationships. The International Commission on Radiological Protection (ICRP) has evaluated all these studies and concluded that the best estimate of lifetime risk of fatal cancer for members of the general population is approximately 500 cases per $1,000,000$ person-rem (ICRP 1991). This is equivalent to one case per 2000 person-rem.

\section{Activation Product Exposure and Dose to Man}

Phosphorus is an essential constituent of the human body, which contains some $0.8 \mathrm{~kg}$ located predominantly in the skeleton. Most phosphorus compounds are readily absorbed in the body following ingestion or inhalation. About 15\% of the phosphorus entering the body is rapidly excreted; $15 \%$ is retained in intracellular fluids with a halflife of 2 days; $40 \%$ is retained in soft tissues with a halflife of 19 days; and 30\% is retained in bone indefinitely (ICRP 1979).

Chromium is found mostly in the skeleton of the human body. Its absorption from the gastrointestinal tract is variable, depending on the chemical compound, but is taken as $10 \%$ for dosimetric purposes. About $30 \%$ of the chromium absorbed is excreted, and 5\% goes to bone where it remains with a biological half-life of 1000 days. The remainder, uniformly distributed throughout the body, is retained in a two-compartment system with half-lives of 6 and 80 days.

Cobalt is found in small quantities in the human body, with the highest concentration in the liver. Depending on the chemical compound, $5 \%$ to $30 \%$ of ingested cobalt is absorbed from the gastrointestinal tract. About $50 \%$ of the absorbed cobalt is excreted, while $5 \%$ goes to the liver and $45 \%$ goes to all other portions of the body. Cobalt is uniformly distributed throughout the body, except for the liver, which has a four-times-higher concentration (ICRP 1979).

Zinc is readily absorbed from the gastrointestinal tract, with about $50 \%$ entering the body and the rest excreted. About 20\% of the zinc entering the body is transferred to the skeleton and remains there with a biological half-life of $\mathbf{4 0 0}$ days. The rest of the zinc is uniformly distributed throughout the body and remains there with half-lives of 20 and 400 days.

In 1988, DOE issued internal dose conversion factors to ensure that doses are calculated in a consistent manner at all DOE facilities (DOE 1988). The factors, based on ICRP recommendations (ICRP 1979), are used in conjunc- 
tion with the models described later in this chapter to calculate all the doses reported in this document.

Future changes are anticipated in the dose calculation methodology. The ICRP has recently issued age-specific dose factors for ingestion of some of the more common isotopes and is developing age-specific dose factors for inhalation of radioisotopes (ICRP 1989).

\section{Models of Activation Product Transport and Dose}

Except for tritium, most of the radioactive materials released from SRS have such low concentrations in the offsite environment that they are not detectable by conventional monitoring techniques. Therefore, radiation doses to offsite individuals and populations are calculated with mathematical models. These models use known transport mechanisms for atmospheric and liquid releases and known major pathways of exposure to man. Modeled atmospheric and aqueous dispersion are periodically verified using environmental tritium measurements (tritium is released during normal SRS operations).

The first models used at SRS to calculate offsite doses were developed by SRTC (Cooper 1975). These models, MREM (atmospheric releases) and RIVDOSE (liquid releases), were first used in 1972. In 1982, MREM and RIVDOSE were replaced with the more technologically advanced models now in use.

SRS annual offsite doses are currently calculated with the transport and dose models developed for the commercial nuclear industry (NRC 1977a; NRC 1977b). The models are implemented at SRS in the following computer programs:

\section{Atmospheric Releases}

- MAXIGASP calculates maximum and average doses to offsite individuals

- POPGASP calculates offsite population collective dose

\section{Liquid Releases}

- LADTAP II calculates both maximum and average doses to offsite individuals and collective dose to the offsite population.
MAXIGASP and POPGASP are SRTC-modified versions of the Nuclear Regulatory Commission (NRC) programs XOQDOQ (Sagendorf et al. 1982) and GASPAR (Eckerman et al. 1980). The modifications were made to meet the requirements for input of physical and biological data specific to SRS. The basic calculations in the XOQDOQ and GASPAR programs have not been modified. LADTAP II (Simpson and McGill 1980) is an essentially unaltered version of the NRC code of the same name. LADTAP XI, a spreadsheet version of LADTAP II, was used for dose modeling for this document.

\section{Modeling Atmospheric Dispersion of Radioactive Releases}

The routine atmospheric transport of radioactive materials from SRS is evaluated on the basis of meteorological conditions measured continuously at seven onsite towers. The towers relay wind speed, wind direction, and atmospheric stability information at 1.5 -second intervals to SRTC via the WIND (Weather INformation and Display) system. A database of this information containing the 60 -min average values for the period 1987-1991 is accessed by the dispersion codes to estimate downwind concentrations of released radionuclides.

Historically, offsite doses have been calculated using $\mathrm{H}$ Area meteorology and assuming that releases occurred at the geographic center of the Site. It has been demonstrated that using data from one of the other onsite meteorological towers has little effect on the maximum individual dose and no effect on the $80-\mathrm{km}$ population dose (Hamby and Parker 1991).

The dispersion of an atmospheric release from SRS is modeled using $\mathrm{XOQDOQ}$, which computes concentrations in the plume as a function of downwind distance and compass sector. The plume is depleted because of dry deposition and radioactive decay. At the user's option, plume concentrations can be reduced by taking into account the effluent's upward displacement, which results from thermal buoyancy and/or momentum effects. This option is not used at SRS (i.e., no credit is taken for plume rise).

The plume concentration information generated by XOQ$D O Q$ then is used by the dose modeling program GASPAR to estimate doses to offsite individuals and populations. GASPAR estimates doses from a number of pathways, which are illustrated in a general sense in Figure 5.1.

The doses estimated by GASPAR are reported on a pathway-specific basis, as follows: 


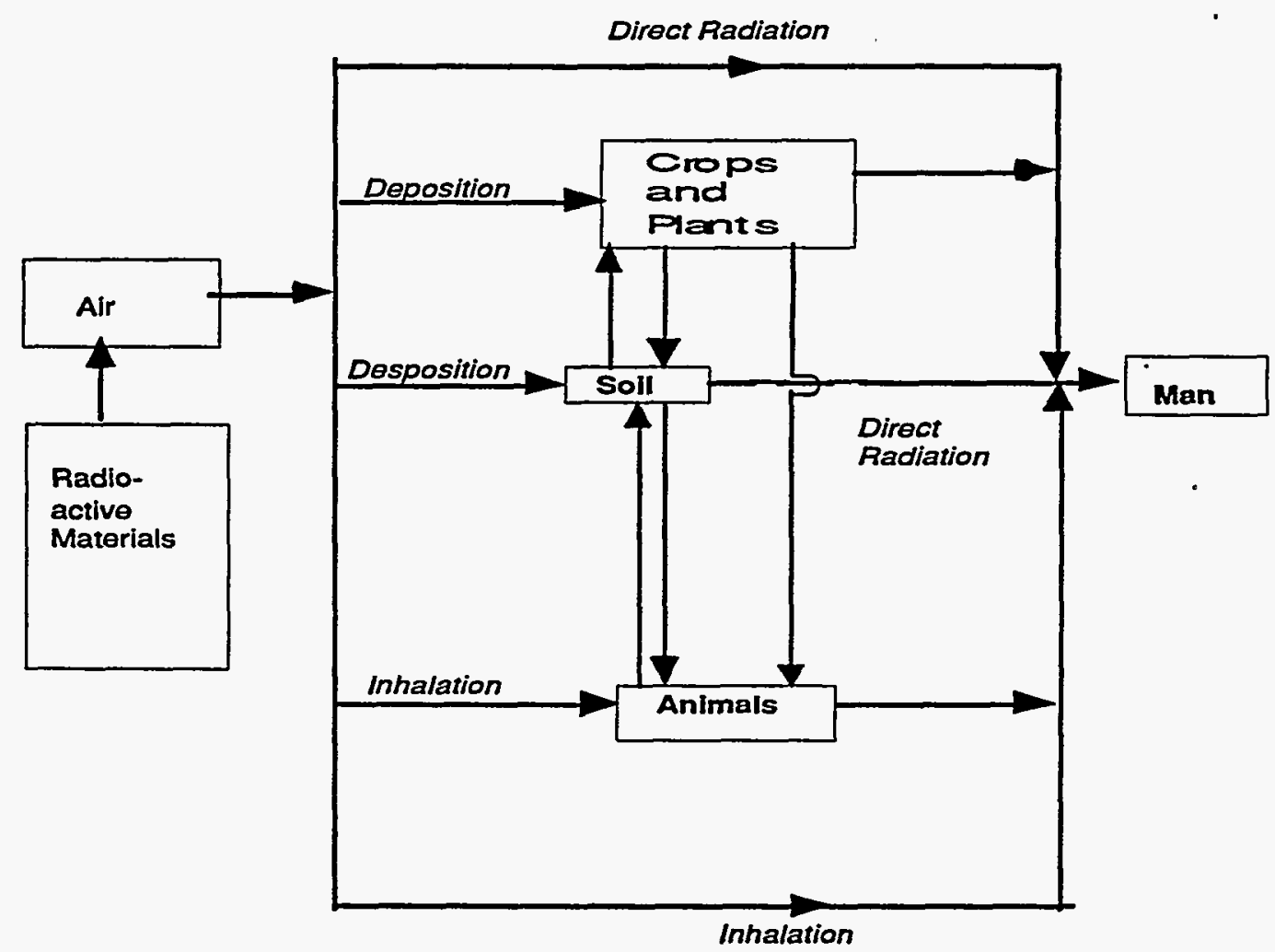

Figure 5.1. Simplified Pathways between Radioactive Materials Released to the Atmosphere and Man 
- Plume-external dose from radioactive materials suspended in the atmosphere

- Ground-external dose from radioactive materials deposited on the ground

- Inhalation-internal dose from inhalation of radioactive materials present in the plume

- Vegetation-internal dose from consumption of contaminated crops

- Milk-intemal dose from milk produced in a contaminated area

- Meat-internal dose from consumption of meat produced in a contaminated area

The codes XOQDOQ (Bauer 1991), GASPAR (Hamby 1992), MAXIGASP and POPGASP (Hamby 1995) have undergone comprehensive reviews in association with the WSRC quality assurance requirements for software.

\section{MAXIGASP}

The calculations required by XOQDOQ and GASPAR to estimate maximum and average individual doses are performed at SRS using the computer program MAXIGASP. MAXIGASP calculates annual average ground-level air concentrations and 50-year committed doses at a number of points along the site boundary in each of 16 compass sectors.

The main outputs from the program are the maximum dose equivalents to an individual along the SRS perimeter. The maximally exposed individual is assumed to reside continuously at the location of highest exposure and to have living and eating habits that maximize dose. These assumptions provide a ceiling on doses from atmospheric releases because no such individual is believed to exist.

The parameters used to calculate doses with MAXIGASP are presented in Table 5-1.

\section{POPGASP}

The calculations required by XOQDOQ and GASPAR to estimate population doses from atmospheric releases are performed at SRS using POPGASP. POPGASP calculates annual average ground-level air concentrations and annual doses for each of 160 regions (16 wind direction sectors at 10 distances per sector) within an 80-kilometer radius of the release location.

In addition to compass sector-specific meteorological information, POPGASP uses sector-specific data on population distribution and composition. Comparable data on milk, meat, and vegetable production/consumption also are used in the code. These databases are extensive and are available for review in the SRS annual environmental reports. With respect to the human parameters used in POPGASP, the key values are shown in Table 5-1.

Table 5-1. Site-Specific Parameters for Atmospheric Releases

\section{Population Group}

$80-\mathrm{km}$ radius

555,100

(1980 Census)

Maximum Individual

(MAXIGASP)

\section{Exposure Pathway}

Inhalation $\left(\mathrm{ms}\left({ }^{3}\right) / \mathrm{yr}\right)$

8,000

Ingestion

Cow's milk (L/yr)

230

Meat (kg/yr)

81

Leafy vegetables $(\mathrm{kg} / \mathrm{yr})$

43

Fruits, grains, and other

leafy vegetables $(\mathrm{kg} / \mathrm{yr})$

External exposure

Transmission factor for

0.7

shielding from buildings

General Population

(POPGASP)

\section{Exposure Pathway}

Inhalation $\left(\mathrm{ms}\left({ }^{3}\right) / \mathrm{yr}\right)$

Ingestion

Cow's milk (L/yr)

120

Meat (kg/yr)

Leafy vegetables $(\mathrm{kg} / \mathrm{yr})$

21

Fruits, grains, and other

163

vegetables $(\mathrm{kg} / \mathrm{yr})$

External exposure

Transmission factor for

0.5 


\section{Modeling Doses from Liquid Releases}

The consequences of liquid releases from SRS are modeled using LADTAP XI, a spreadsheet version of LADTAP II (Liquid Annual Doses To All Persons). The potential pathways of exposure from liquid releases to the environment are shown in Figure 5.2. The pathwayspecific doses calculated by LADTAP are grouped into the following five categories:

- Potable drinking water-internal dose from consuming drinking water of Savannah River origin

- Sport fish and commercial fish-internal dose from consuming fish of Savannah River origin

- Salt water invertebrates-internal dose from consuming shellfish from estuaries of the Savannah River

- Recreation-external dose from recreation activities (boating, swimming, and shoreline) in and along the Savannah River

- Irrigation-internal dose from foods produced by irrigation with Savannah River water. (There are no known users of the river for this purpose.)

LADTAP XI estimates individual and population doses at specific downstream locations. The only removal mechanism included in the transport model as it is used at -SRS is radioactive decay. No credit is taken for adsorption on stream sediments.

One major difference between LADTAP II and LADTAP XI is the method of calculating population dose. LADTAP II uses only a fraction of the dose from fish caught in the Savannah River. The fraction is the ratio of the 80-kilometer harvest to the United States harvest. LADTAP XL assigns the dose from all fish to the population dose. LADTAP XI, used for dose calculations in this document, is conservative and reports the maximum possible population dose.

One major assumption inherent in the application of LADTAP XL to SRS releases is that liquid discharges undergo complete mixing in the Savannah River before reaching potentially exposed populations. This assumption is supported by repeated measurements indicating that complete mixing occurs in the river between the SRS and the Highway 301 sampling station (Arnett et al. 1994).
LADTAP XI generates maximum individual and population doses for all of the exposure pathways identified above. Though standard input values were provided in LADTAP II, SRS calculations are performed with sitespecific information. Principal input values used in the SRS version of LADTAP XI are shown in Table 5-2. Additional site specific parameters for liquid releases are shown in Table 5-3.

Table 5-2. Site-Specific Parameters for Liquid Releases

Maximally Exposed

Individual Dose Assessments

(LADTAP XL)

\section{Site Parameters}

Savannah River flow rate

(cu ft/sec)

Transit time from

Measured average

SRS to Savannah River (hr)

Shore-width factor

24

Human Parameters-

0.2

Maximum Individual

Water consumption

730

(L/yr)

Fish consumption

(kg/yr)

Shellfish consumption

8

(kg/yr)

Shoreline recreation

(hr/yr)

Swimming

(hr/yr)

Boating

(hr/yr) 


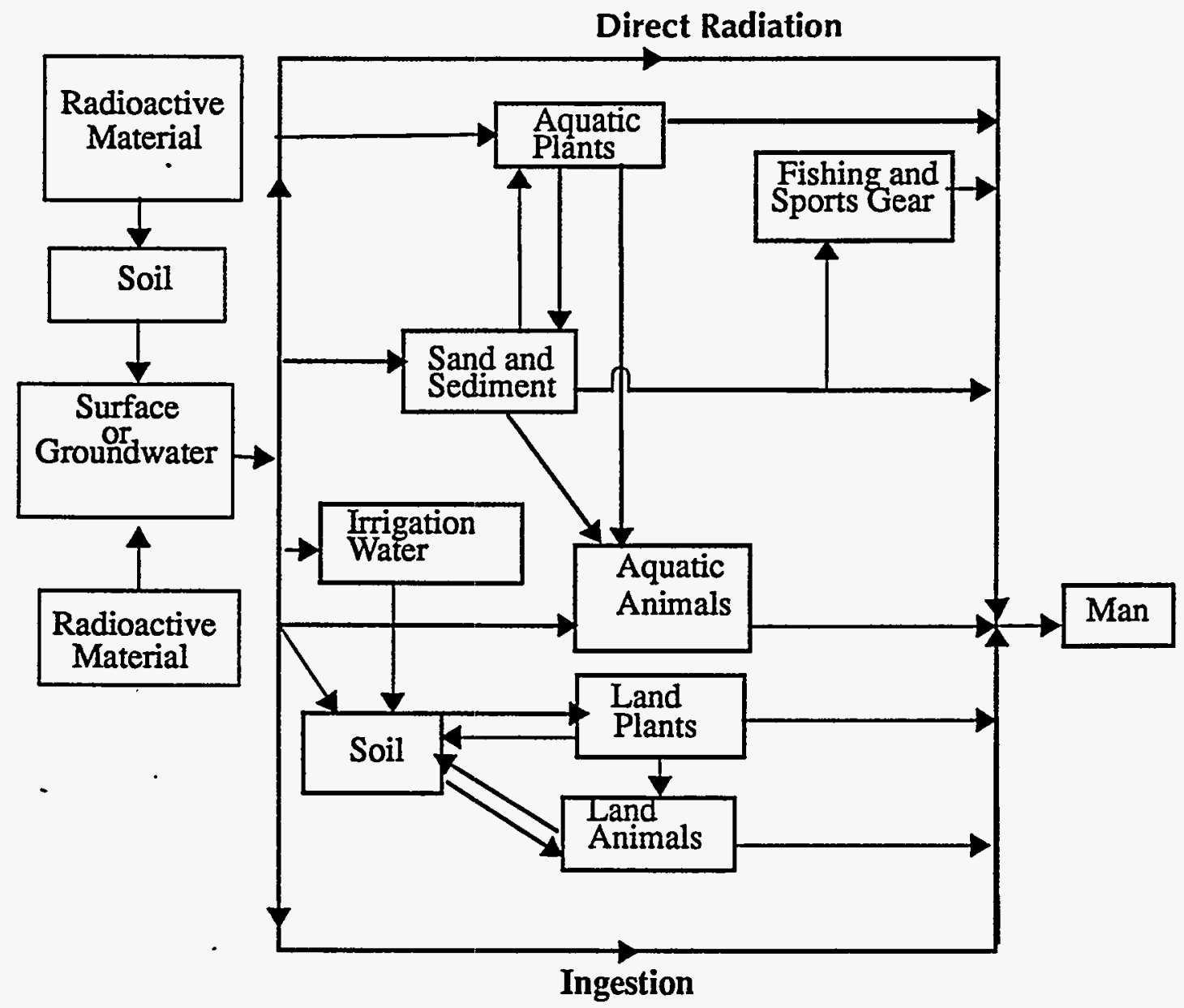

Figure 5.2. Simplified Pathways between Radioactive Materials Released to Groundwater or Surface Waters and Man 
Radioisotope concentrations in the Savannah River are diluted by the inflow of streams downriver of SRS. Additional dilution occurs at the Beaufort-Jasper, South Carolina water treatment plant from the inflow of surface water and at the Port Wentworth, Georgia water treatment plant because of the close proximity of Abercom Creek to the intake. Because tritium is readily measured in the processed water of each system, a derived river flow rate that allows better estimates of radionuclide concentrations at these treatment plants can be calculated.

Table 5-3. Additional Site-Specific Parameters for Liquid Releases

\section{Average Individual/Population Dose Assessments (LADTAP XL)}

\section{Site Parameters}

Savannah River flow rate $\left(\mathrm{ft}^{3} / \mathrm{sec}\right)$

Transit time from SRS to Savannah River (hr)

Transit time from SRS to water treatment plants (hr)

Retention time in water treatment system (hr)

Shore-width factor

River dilution in estuary

Aquatic food harvest, edible portions $(\mathrm{kg} / \mathrm{yr})$

Sport fish

Commercial fish

Saltwater invertebrates

\section{Human Parameters}

Water consumption

(L/yr)

Fish consumption

$(\mathrm{kg} / \mathrm{yr})$

Shellfish consumption (kg/yr)

\section{9}

24

72

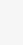

Average

Individual

2
Average Individual/Population Dose Assessments

(LADTAP XL)

Usage

(person-hr)

Shoreline recreation

960,000

(hr/yr)

160,000

Swimming

(hr/yr)

Boating

(hr/yr)

\section{Validation of Transport Models Using Monitoring Data}

\section{Atmospheric Releases}

The radionuclide concentrations predicted by XOQDOQ are compared routinely with measured values of tritium concentrations in air to evaluate the performance of the code. (Tritium is the only radionuclide released by SRS that can be routinely detected offsite with conventional measuring techniques.) Predicted values tend to exceed observed values yet not to a degree that would indicate an excessively conservative approach.

Other comparisons of predicted and measured concentrations have been made (Marter 1984) and have exhibited similar results. The available data suggest that calculated concentrations of tritium in air generally are conservative estimates of actual offsite values.

\section{Liquid Releases}

Throughout the period from 1954 through 1994, SRS liquid releases were dominated by tritium. Measured, rather than estimated, tritium concentrations therefore are used for the downriver locations that are the most important in terms of dose calculations:

- just below SRS

- at the Beaufort-Jasper water treatment plant

- at the Port Wentworth water treatment plant. 
In addition to supplying measured tritium concentrations, such data also allow calculation of Savannah River dilution factors for these locations. Having accurate estimates of river dilution characteristics significantly enhances the ability to predict downriver concentrations of other radionuclides such as activation products.

\section{Impact of SRS Activation Product Releases on the Offsite Population}

The computer codes MAXIGASP, POPGASP, and LADTAP XL have been used to calculate effective dose equivalents that have been theoretically received by segments of the offsite population from exposure to activation products over the course of site operations. The results are shown are in Table 5-4 for atmospheric releases and Tables 5-5 through 5-8 for liquid releases. Liquid activation product release levels have consistently exceeded atmospheric release levels. Of the four activation product radionuclides considered in this report, only ${ }^{60} \mathrm{Co}$ has been released to the atmosphere.

\section{Doses from Atmospheric Releases}

As shown in Table 5-4, the largest annual effective dose equivalent theoretically received by an adult occurred in 1968. The effective dose equivalent from ${ }^{60} \mathrm{Co}$ to the "maximum" adult at the site perimeter in 1968 was 0.4 mrem.

"Maximum" individuals are hypothetical persons who live at the SRS boundary and subsist on diets of locally produced milk, meat, and vegetables. No such individuals are known to exist. Nevertheless, if one examines the case of the maximally exposed adult individual living continuously at the site perimeter throughout the period from 1954 through 1994, the cumulative effective dose equivalent from atmospheric releases of ${ }^{60} \mathrm{Co}$ has been estimated at 0.76 mrem (Table 5-4). This value is the upper bounding case and made a minor contribution to the overall dose received during that time.

A person living in the Central Savannah River Area (CSRA) received an effective dose of approximately $11,800 \mathrm{mrem}$ from exposure to natural sources of radioactivity and an additional 2,600 mrem from medical practices and various consumer products during the 40-year period (WSRC 1994). Therefore, the cumulative dose contribution to this individual from SRS atmospheric ${ }^{60}$ Co releases is about $0.005 \%$ of that received from sources unrelated to SRS.

Because the contribution of SRS ${ }^{60}$ Co releases to any individual's total radiation dose is so small, it is necessary to pool the radiation exposures from a given population if an assessment of potential health risks is desired. The population dose within an 80-kilometer radius is the figure of merit frequently used to make such an assessment.

The population doses reported in Table $5-4$ are based on 1980 census data $(555,100$ people within $80 \mathrm{~km})$ and current meteorological and dose factor data. If it is assumed that this population has lived in the SRS vicinity throughout the period of site operations, the total collective effective dose received by the population through 1994 would be 1.0 person-rem.

The risks associated with this collective dose are quite small. The risk estimate using ICRP factors for the number of excess fatal cancers potentially induced by a collective dose of 1.0 person-rem is 0.0005 . Conversely, in the same population, at the current fatal cancer frequency of $16 \%$ (EPA 1989b), there will be about 90,000 spontaneous fatal cancers from all other causes. Therefore, it is impossible to demonstrate that a relationship exists between any of the cancer deaths occurring in this population and the releases of ${ }^{60} \mathrm{Co}$ to the atmosphere.

\section{Individual Doses from Liquid Releases}

Dose equivalents potentially received by downstream consumers of Savannah River water and fish are shown in Tables 5-5 through 5-8. The release levels reflect contributions from all known effluents. Dose equivalents have been calculated for a "maximum" individual living just below SRS who subsisted on a diet of untreated Savannah River water and Savannah River fish. Such doses are believed to represent the bounding case for liquid releases. Drinking water doses have also been calculated for "maximum" individuals at both the downstream water treatment plants and for the populations served by these plants.

\section{Phosphorus-32}

The maximum annual dose occurred in 1965 . The effective dose equivalent to the maximally exposed individual for that year has been estimated as 16 mrem. If the hypothetical "maximum" exposure conditions are used as the bounding case for the 40-year period of site operations considered here, the cumulative effective dose to such an individual would be about $46 \mathrm{mrem}$. Approximately $99 \%$ of this dose is from eating fish from the Savannah River and the remainder is from drinking untreated river water. 
Table 5-4. Atmospheric Co-60 Releases and Dose

\begin{tabular}{|c|c|c|c|c|}
\hline Year & $\begin{array}{l}\text { Release } \\
\text { A Area } \\
\text { (CI) }\end{array}$ & $\begin{array}{c}\text { Release } \\
\text { F Area \& H Area } \\
\text { (CI) }\end{array}$ & $\begin{array}{l}\text { Maximum Individual } \\
\text { Dose at Boundary } \\
\text { (mrem) }\end{array}$ & $\begin{array}{c}\text { Population } \\
\text { Dose } \\
\text { (person-rem) }\end{array}$ \\
\hline \multicolumn{5}{|l|}{1954} \\
\hline \multicolumn{5}{|c|}{$1955^{\circ}$} \\
\hline \multicolumn{5}{|l|}{1956} \\
\hline \multicolumn{5}{|l|}{1957} \\
\hline \multicolumn{5}{|l|}{1958} \\
\hline & & & & \\
\hline \multicolumn{5}{|l|}{$\begin{array}{l}1959 \\
1960\end{array}$} \\
\hline \multicolumn{5}{|l|}{1961} \\
\hline \multicolumn{5}{|l|}{1962} \\
\hline 1963 & & & & \\
\hline \multicolumn{5}{|l|}{1964} \\
\hline \multicolumn{5}{|l|}{1965} \\
\hline \multicolumn{5}{|l|}{1966} \\
\hline \multicolumn{5}{|l|}{1967} \\
\hline 1968 & $3.9 \times 10^{-2}$ & & $4.1 \times 10^{-1}$ & $4.7 \times 10^{-1}$ \\
\hline 1969 & $1.1 \times 10^{-2}$ & & $1.2 \times 10^{-1}$ & $1.3 \times 10^{-1}$ \\
\hline 1970 & $2.8 \times 10^{-3}$ & & $3.0 \times 10^{-2}$ & $3.4 \times 10^{-2}$ \\
\hline 1971 & $26 \times 10^{-3}$ & $2.0 \times 10^{-2}$ & $3.0 \times 10^{-2}$ & $20 \times 10^{-1}$ \\
\hline 1972 & $7.1 \times 10^{-3}$ & $9.0 \times 10^{-5}$ & $7.5 \times 10^{-2}$ & $8.7 \times 10^{-2}$ \\
\hline 1973 & $1.8 \times 10^{-3}$ & & $1.9 \times 10^{-2}$ & $2.2 \times 10^{-2}$ \\
\hline 1974 & $3.9 \times 10^{-3}$ & & $4.1 \times 10^{-2}$ & $4.7 \times 10^{-2}$ \\
\hline 1975 & $1.1 \times 10^{-3}$ & & $1.2 \times 10^{-2}$ & $1.3 \times 10^{-2}$ \\
\hline 1976 & $1.3 \times 10^{-4}$ & & $1.4 \times 10^{-3}$ & $1.6 \times 10^{-3}$ \\
\hline 1977 & $3.8 \times 10^{-4}$ & & $4.0 \times 10^{-3}$ & $4.6 \times 10^{-3}$ \\
\hline 1978 & $3.8 \times 10^{-4}$ & & $4.0 \times 10^{-3}$ & $4.6 \times 10^{-3}$ \\
\hline 1979 & $4.0 \times 10^{-4}$ & & $4.2 \times 10^{-3}$ & $4.8 \times 10^{-3}$ \\
\hline 1980 & $6.2 \times 10^{-4}$ & & $6.6 \times 10^{-3}$ & $7.5 \times 10^{-3}$ \\
\hline 1981 & $8.9 \times 10^{-5}$ & & $9.4 \times 10^{-4}$ & $1.1 \times 10^{-3}$ \\
\hline 1982 & $4.4 \times 10^{-5}$ & & $4.7 \times 10^{-4}$ & $5.3 \times 10^{-4}$ \\
\hline 1983 & $1.7 \times 10^{-4}$ & & $1.8 \times 10^{-3}$ & $2.1 \times 10^{-3}$ \\
\hline 1984 & $5.4 \times 10^{-5}$ & & $5.7 \times 10^{-4}$ & $6.5 \times 10^{-4}$ \\
\hline \multicolumn{5}{|l|}{1985} \\
\hline 1986 & & $8.0 \times 10^{-6}$ & $1.4 \times 10^{-6}$ & $6.7 \times 10^{-5}$ \\
\hline \multicolumn{5}{|l|}{1987} \\
\hline 1988 & & $3.0 \times 10^{-6}$ & $5.2 \times 10^{-7}$ & $2.5 \times 10^{-5}$ \\
\hline \multicolumn{5}{|l|}{1989} \\
\hline \multicolumn{5}{|l|}{1990} \\
\hline \multicolumn{5}{|l|}{1991} \\
\hline \multicolumn{5}{|l|}{1992} \\
\hline \multicolumn{5}{|l|}{1993} \\
\hline \multicolumn{5}{|l|}{1994} \\
\hline Total & $7.2 \times 10^{-2}$ & $2.0 \times 10^{-2}$ & $7.6 \times 10^{-1}$ & $1.0 \times 10^{0}$ \\
\hline
\end{tabular}


Assessment of Activation Products

in the Savannah River Site Environment (U)

Table 5-5. Liquid ${ }^{32} \mathrm{P}$ Releases and Dose

\begin{tabular}{|c|c|c|c|c|c|c|c|c|c|c|c|}
\hline Yeas & $\begin{array}{l}\text { River } \\
\text { Flow } \\
\text { Rate } \\
\left(\mathrm{m}^{3} / s\right)\end{array}$ & $\begin{array}{c}\text { B-J } \\
\text { Derived } \\
\text { Flow } \\
\text { Rate } \\
\left(\mathrm{m}^{3} / \mathrm{s}\right)\end{array}$ & $\begin{array}{c}\text { PW } \\
\text { Denived } \\
\text { Flow } \\
\text { Rate } \\
\left(\mathrm{m}^{3} / \mathrm{s}\right)\end{array}$ & $\begin{array}{l}\text { Releases } \\
\text { to } \\
\text { Streams } \\
\text { (Ci) }\end{array}$ & $\begin{array}{c}\text { Max } \\
\text { Ind } \\
\text { Below SRS } \\
\text { (mrem) }\end{array}$ & 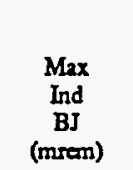 & $\begin{array}{c}\text { Max } \\
\text { Ind } \\
\text { PW } \\
\text { (mrem) }\end{array}$ & $\begin{array}{c}\text { Pop } \\
\text { Dose } \\
\text { BJ } \\
\text { (per-rem) }\end{array}$ & $\begin{array}{c}\text { Pop } \\
\text { Dose } \\
\text { PW } \\
\text { (per-rem) }\end{array}$ & $\begin{array}{c}\text { Pop } \\
\text { Dose } \\
80 \mathrm{~km} \\
\text { (per-rem) }\end{array}$ & $\begin{array}{c}\text { Pop } \\
\text { Dore } \\
\text { Total } \\
\text { (perrem) }\end{array}$ \\
\hline 1954 & 209 & & 263 & & & & & & & & \\
\hline 1955 & 169 & & 213 & & & & & & & & \\
\hline 1956 & 179 & & 225 & & & & & & & & \\
\hline 1957 & 235 & & 297 & & & & & & & & \\
\hline 1958 & 313 & & 394 & & & & & & & & \\
\hline 1959 & 276 & & 348 & & & & & & & & \\
\hline 1960 & 371 & & 468 & & & & & & & & \\
\hline 1961 & 309 & & 389 & & & & & & & & \\
\hline 1962 & 300 & & 377 & & & & & & & & \\
\hline 1963 & 315 & & 397 & & & & & & & & \\
\hline 1964 & 580 & & 731 & $3.1 \times 10^{0}$ & $2.2 \times 10^{0}$ & & $7.0 \times 10^{-4}$ & & $4.6 \times 10^{-3}$ & $5.4 \times 10^{0}$ & $5.4 \times 10^{0}$ \\
\hline 1965 & 362 & 800 & 456 & $1.4 \times 10^{1}$ & $1.6 \times 10^{1}$ & $28 \times 10^{-3}$ & $5.0 \times 10^{-3}$ & $6.3 \times 10^{-2}$ & $3.3 \times 10^{-2}$ & $3.8 \times 10^{1}$ & $3.8 \times 10^{1}$ \\
\hline 1966 & 316 & 520 & 399 & $1.0 \times 10^{1}$ & $1.4 \times 10^{1}$ & $3.3 \times 10^{-3}$ & $4.3 \times 10^{-3}$ & $7.3 \times 10^{-2}$ & $2.8 \times 10^{-2}$ & $3.3 \times 10^{1}$ & $3.3 \times 10^{1}$ \\
\hline 1967 & 299 & 625 & 377 & $4.2 \times 10^{0}$ & $5.9 \times 10^{0}$ & $1.1 \times 10^{-3}$ & $1.8 \times 10^{-3}$ & $2.5 \times 10^{-2}$ & $1.2 \times 10^{-2}$ & $1.0 \times 10^{1}$ & $1.4 \times 10^{1}$ \\
\hline 1968 & 273 & 470 & 343 & $2.4 \times 10^{0}$ & $3.8 \times 10^{0}$ & $8.7 \times 10^{-4}$ & $1.2 \times 10^{-3}$ & $1.9 \times 10^{-2}$ & $7.8 \times 10^{-3}$ & $9.1 \times 10^{0}$ & $9.2 \times 10^{0}$ \\
\hline 1969 & 310 & 624 & 390 & $7.3 \times 10^{-1}$ & $1.0 \times 10^{0}$ & $2.0 \times 10^{-4}$ & $3.1 \times 10^{-4}$ & $4.3 \times 10^{-3}$ & $2.1 \times 10^{-3}$ & $24 \times 10^{0}$ & $2.4 \times 10^{0}$ \\
\hline 1970 & 232 & 72 & 293 & $7.7 \times 10^{-1}$ & $1.4 \times 10^{0}$ & $1.7 \times 10^{-4}$ & $4.4 \times 10^{-4}$ & $3.7 \times 10^{-3}$ & $2.9 \times 10^{-3}$ & $3.4 \times 10^{0}$ & $3.4 \times 10^{0}$ \\
\hline 1971 & 303 & 1245 & 381 & $9.2 \times 10^{-1}$ & $1.3 \times 10^{0}$ & $1.2 \times 10^{-4}$ & $4.0 \times 10^{-4}$ & $2.7 \times 10^{-3}$ & $2.7 \times 10^{-3}$ & $3.1 \times 10^{0}$ & $3.1 \times 10^{0}$ \\
\hline 1972 & 318 & 775 & 401 & $3.0 \times 10^{-1}$ & $4.0 \times 10^{-1}$ & $6.5 \times 10^{-5}$ & $1.3 \times 10^{-4}$ & $1.5 \times 10^{-3}$ & $8.3 \times 10^{-4}$ & $9.6 \times 10^{-1}$ & $9.6 \times 10^{-1}$ \\
\hline 1973 & 409 & 656 & 468 & $1.3 \times 10^{-1}$ & $1.4 \times 10^{-1}$ & $3.4 \times 10^{-5}$ & $4.8 \times 10^{-5}$ & $7.5 \times 10^{-4}$ & $3.1 \times 10^{-4}$ & $3.3 \times 10^{-1}$ & $3.3 \times 10^{-1}$ \\
\hline 1974 & 314 & 640 & 373 & $1.4 \times 10^{-2}$ & $1.9 \times 10^{-2}$ & $3.7 \times 10^{-6}$ & $6.3 \times 10^{-6}$ & $8.1 \times 10^{-5}$ & $4.1 \times 10^{-5}$ & $4.5 \times 10^{-2}$ & $4.6 \times 10^{-2}$ \\
\hline 1975 & 436 & 877 & 538 & $2.0 \times 10^{-3}$ & $1.9 \times 10^{-3}$ & $3.8 \times 10^{-7}$ & $6.2 \times 10^{-7}$ & $8.4 \times 10^{-6}$ & $4.1 \times 10^{-6}$ & $4.7 \times 10^{-3}$ & $4.7 \times 10^{-3}$ \\
\hline 1976 & 394 & 996 & 472 & $1.7 \times 10^{-2}$ & $1.8 \times 10^{-2}$ & $2.9 \times 10^{-6}$ & $6.0 \times 10^{-6}$ & $6.3 \times 10^{-5}$ & $4.0 \times 10^{-5}$ & $4.4 \times 10^{-2}$ & $4.4 \times 10^{-2}$ \\
\hline 1977 & 330 & 562 & 433 & $6.4 \times 10^{-3}$ & $8.3 \times 10^{-3}$ & $1.9 \times 10^{-6}$ & $2.5 \times 10^{-6}$ & $4.2 \times 10^{-5}$ & $1.6 \times 10^{-5}$ & $2.0 \times 10^{-2}$ & $2.0 \times 10^{-2}$ \\
\hline 1978 & 298 & 689 & 324 & & & & & & & & \\
\hline 1979 & 375 & 989 & 495 & $4.0 \times 10^{-3}$ & $4.5 \times 10^{-3}$ & $6.8 \times 10^{-7}$ & $1.4 \times 10^{-6}$ & $1.5 \times 10^{-5}$ & $8.9 \times 10^{-6}$ & $1.1 \times 10^{-2}$ & $1.1 \times 10^{-2}$ \\
\hline 1980 & 374 & 863 & 488 & & & & & & & & \\
\hline 1981 & 187 & 331 & 243 & & & & & & & & \\
\hline 1982 & 203 & 555 & 287 & & & & & & & & \\
\hline 1983 & 350 & 361 & 417 & & & & & & & & \\
\hline 1984 & 361 & 747 & 487 & & & & & & & & \\
\hline 1985 & 203 & 263 & 254 & & & & & & & & \\
\hline 1986 & 175 & 235 & 213 & & & & & & & & \\
\hline 1987 & 254 & 374 & 357 & & & & & & & & \\
\hline 1988 & 152 & 211 & 203 & & & & & & & & \\
\hline 1989 & 226 & 240 & 245 & & & & & & & & \\
\hline 1990 & 336 & 447 & 367 & & & & & & & & \\
\hline 1991 & 328 & 550 & 453 & & & & & & & & \\
\hline 1992 & 331 & 350 & 279 & & & & & & & & \\
\hline 1993 & 419 & 566 & 416 & & & & & & & & \\
\hline 1994 & 347 & 421 & 348 & & & & & & & & \\
\hline TOTAL & & & & $3.6 \times 10^{1}$ & $4.6 \times 10^{1}$ & $8.7 \times 10^{-3}$ & $1.4 \times 10^{-2}$ & $1.9 \times 10^{-1}$ & $9.5 \times 10^{-2}$ & $1.1 \times 10^{2}$ & $1.1 \times 10^{2}$ \\
\hline
\end{tabular}

a Flow rates based on USGS measurements and Hayes, 1991. 
Table 5-6. Liquid ${ }^{51} \mathrm{Cr}$ Releases and Dose

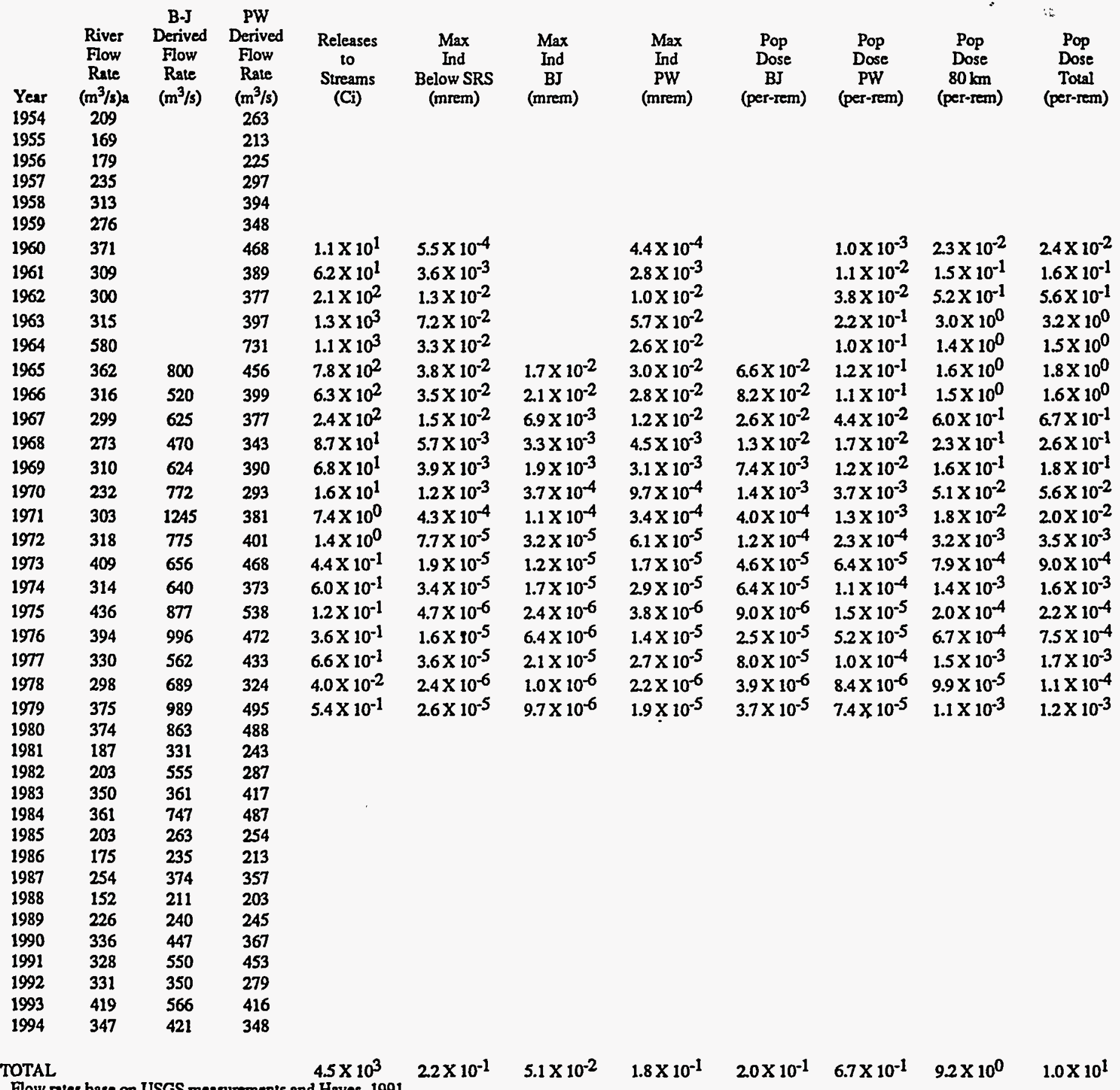

a Flow rates base on USGS measurements and Hayes, 1991. 
Table 5-7. Liquid ${ }^{60}$ Co Releases and Dose

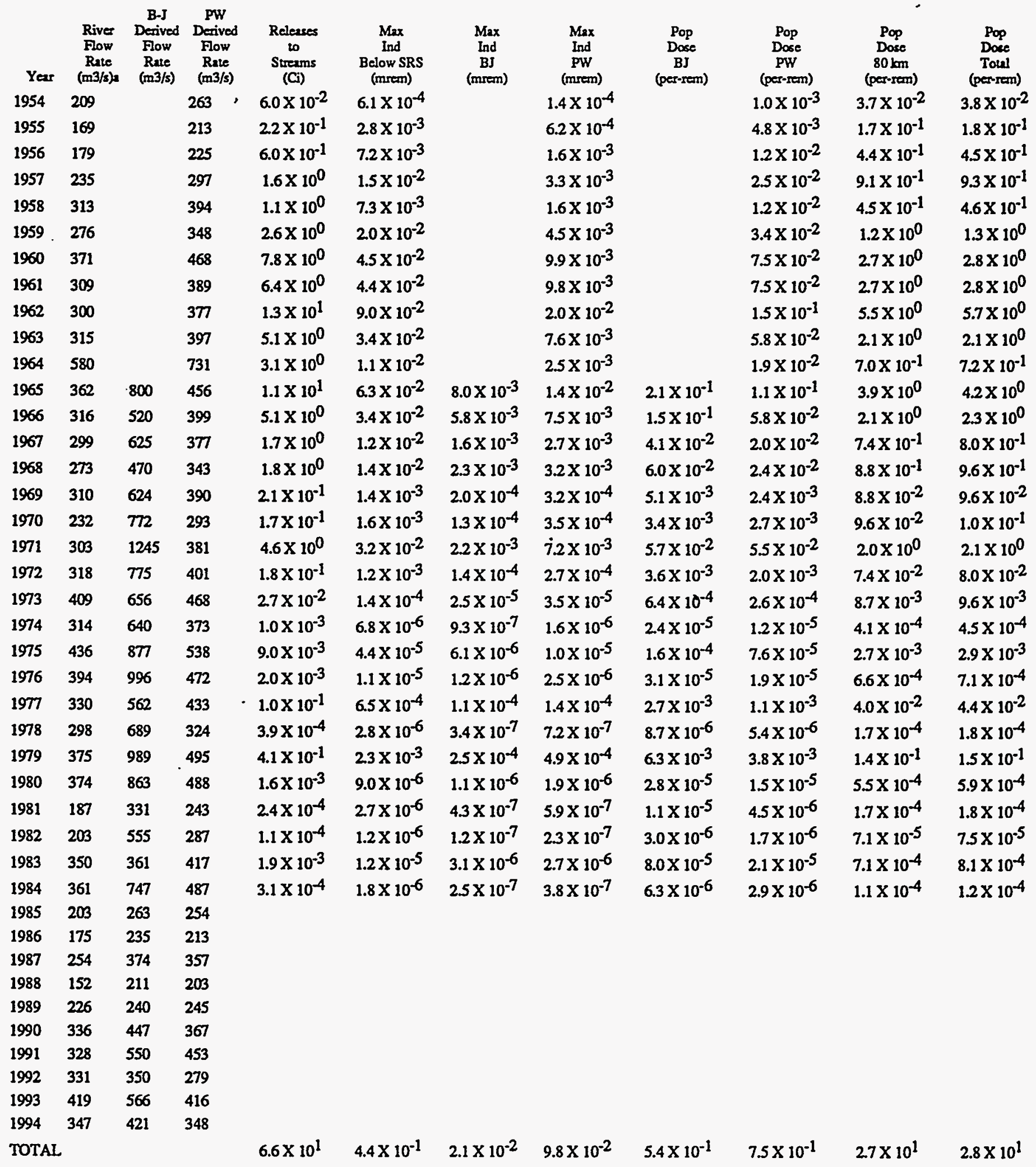

a Flow rates based on USGS measurements and Hayes, 1991. 
Table 5-8. Liquid ${ }^{65} \mathrm{Zn}$ Releases and Dose

\begin{tabular}{|c|c|c|c|c|c|c|c|c|c|c|c|}
\hline Year & $\begin{array}{l}\text { River } \\
\text { Flow } \\
\text { Rate } \\
\left(\mathrm{m}^{3} / \mathrm{s}\right) \mathrm{a}\end{array}$ & $\begin{array}{c}\text { B-J } \\
\text { Derived } \\
\text { Flow } \\
\text { Rate } \\
\left(\mathrm{m}^{3} / \mathrm{s}\right)\end{array}$ & $\begin{array}{c}\text { PW } \\
\text { Derived } \\
\text { Flow } \\
\text { Rate } \\
\left(\mathrm{m}^{3} / \mathrm{s}\right)\end{array}$ & $\begin{array}{l}\text { Releases } \\
\text { to } \\
\text { Streams } \\
(C i)\end{array}$ & $\begin{array}{c}\text { Max } \\
\text { Ind } \\
\text { Below SRS } \\
\text { (mrem) }\end{array}$ & $\begin{array}{c}\text { Max } \\
\text { Ind } \\
\text { BJ } \\
\text { (mrem) }\end{array}$ & $\begin{array}{c}\text { Max } \\
\text { Ind } \\
\text { PW } \\
\text { (mrem) }\end{array}$ & $\begin{array}{c}\text { Pop } \\
\text { Dose } \\
\text { BJ } \\
\text { (per-rem) }\end{array}$ & $\begin{array}{c}\text { Pop } \\
\text { Dose } \\
\text { PW } \\
\text { (per-rem) }\end{array}$ & $\begin{array}{c}\text { Pop } \\
\text { Dose } \\
80 \mathrm{~km} \\
\text { (per-rem) }\end{array}$ & $\begin{array}{c}\text { Pop } \\
\text { Dose } \\
\text { Total } \\
\text { (per-rem) }\end{array}$ \\
\hline 1954 & 209 & & 263 & & & & & & & & \\
\hline 1955 & 169 & & 213 & & & & & & & & \\
\hline 1956 & 179 & & 225 & & & & & & & & \\
\hline 1957 & 235 & & 297 & & & & & & & & \\
\hline 1958 & 313 & & 394 & & & & & & & $\cdot$ & \\
\hline 1959 & 276 & & 348 & & & & & & & & \\
\hline 1960 & 371 & & 468 & $4.3 \times 10^{0}$ & $2.0 \times 10^{-1}$ & & $2.8 \times 10^{-3}$ & & $2.2 \times 10^{-2}$ & $2.9 \times 10^{1}$ & \\
\hline 1961 & 309 & & 389 & $2.1 \times 10^{1}$ & $1.1 \times 10^{0}$ & & $1.7 \times 10^{-2}$ & & $1.3 \times 10^{-1}$ & $1.7 \times 10^{2}$ & \\
\hline 1962 & 300 & & 377 & $3.2 \times 10^{1}$ & $1.8 \times 10^{0}$ & & $2.6 \times 10^{-2}$ & & $2.1 \times 10^{-1}$ & $2.7 \times 10^{2}$ & \\
\hline 1963 & 315 & & 397 & $3.4 \times 10^{1}$ & $1.8 \times 10^{0}$ & & $2.7 \times 10^{-2}$ & & $2.1 \times 10^{-1}$ & $2.7 \times 10^{2}$ & \\
\hline 1964 & 580 & & 731 & $2.0 \times 10^{1}$ & $5.8 \times 10^{-1}$ & & $8.5 \times 10^{-3}$ & & $6.7 \times 10^{-2}$ & $8.7 \times 10^{1}$ & $8.7 \times 10^{1}$ \\
\hline 1965 & 362 & 800 & 456 & $8.9 \times 10^{0}$ & $4.2 \times 10^{-1}$ & $3.5 \times 10^{-3}$ & $6.1 \times 10^{-3}$ & $9.1 \times 10^{-2}$ & $4.8 \times 10^{-2}$ & $6.3 \times 10^{1}$ & $6.3 \times 10^{1}$ \\
\hline 1966 & 316 & 520 & 399 & $7.6 \times 10^{0}$ & $4.1 \times 10^{-1}$ & $4.5 \times 10^{-3}$ & $5.9 \times 10^{-3}$ & $1.2 \times 10^{-1}$ & $4.6 \times 10^{-2}$ & $6.1 \times 10^{1}$ & $6.1 \times 10^{1}$ \\
\hline 1967 & 299 & 625 & 377 & $7.3 \times 10^{0}$ & $4.1 \times 10^{-1}$ & $3.6 \times 10^{-3}$ & $6.0 \times 10^{-3}$ & $9.6 \times 10^{-2}$ & $4.7 \times 10^{-2}$ & $6.2 \times 10^{1}$ & $6.2 \times 10^{1}$ \\
\hline 1968 & 273 & 470 & 343 & $4.5 \times 10^{0}$ & $28 \times 10^{-1}$ & $3.0 \times 10^{-3}$ & $4.1 \times 10^{-3}$ & $7.8 \times 10^{-2}$ & $3.2 \times 10^{-2}$ & $4.2 \times 10^{1}$ & $4.2 \times 10^{1}$ \\
\hline 1969 & 310 & 624 & 390 & $1.5 \times 10^{0}$ & $8.4 \times 10^{-2}$ & $7.6 \times 10^{-4}$ & $1.2 \times 10^{-3}$ & $2.0 \times 10^{-2}$ & $9.5 \times 10^{-3}$ & $1.3 \times 10^{1}$ & $1.3 \times 10^{1}$ \\
\hline 1970 & 232 & 772 & 293 & $5.1 \times 10^{-1}$ & $3.7 \times 10^{-2}$ & $2.1 \times 10^{-4}$ & $5.4 \times 10^{-4}$ & $5.4 \times 10^{-3}$ & $4.2 \times 10^{-3}$ & $5.6 \times 10^{0}$ & $5.6 \times 10^{0}$ \\
\hline 1971 & 303 & 1245 & 381 & $1.8 \times 10^{0}$ & $9.8 \times 10^{-2}$ & $4.4 \times 10^{-4}$ & $1.4 \times 10^{-3}$ & $1.2 \times 10^{-2}$ & $1.1 \times 10^{-2}$ & $1.5 \times 10^{1}$ & $1.5 \times 10^{1}$ \\
\hline 1972 & 318 & 775 & 401 & & & & & & & & \\
\hline 1973 & 409 & 656 & 468 & & & & & & & & \\
\hline 1974 & 314 & 640 & 373 & $1.4 \times 10^{-1}$ & $7.6 \times 10^{-3}$ & $6.8 \times 10^{-5}$ & $1.2 \times 10^{-4}$ & $1.8 \times 10^{-3}$ & $9.1 \times 10^{-4}$ & $1.1 \times 10^{0}$ & $1.1 \times 10^{0}$ \\
\hline 1975 & 436 & 877 & 538 & $2.0 \times 10^{-3}$ & $7.8 \times 10^{-5}$ & $7.1 \times 10^{-7}$ & $1.2 \times 10^{-6}$ & $1.9 \times 10^{-5}$ & $9.1 \times 10^{-6}$ & $1.2 \times 10^{-2}$ & $1.2 \times 10^{-2}$ \\
\hline 1976 & 394 & 996 & 472 & & & & & & & & \\
\hline 1977 & 330 & 562 & 433. & & & & & & & & \\
\hline 1978 & 298 & 689 & 324 & & & & & & & & \\
\hline 1979 & 375 & 989 & 495 & & & & & & & & \\
\hline 1980 & 374 & 863 & 488 & & & & & & & & \\
\hline 1981 & 187 & 331 & 243 & & & & & & & & \\
\hline 1982 & 203 & 555 & 287 & & & & & & & & \\
\hline 1983 & 350 & 361 & 417 & & & & & & & & \\
\hline 1984 & 361 & 747 & 487 & & & & & & & & \\
\hline 1985 & 203 & 263 & 254 & & & & & & & & \\
\hline 1986 & 175 & 235 & 213 & & & & & & & & \\
\hline 1987 & 254 & 374 & 357 & & & & & & & & \\
\hline 1988 & 152 & 211 & 203 & & & & & & & & \\
\hline 1989 & 226 & 240 & 245 & & & & & & & & \\
\hline 1990 & 336 & 447 & 367 & & & & & & & & \\
\hline 1991 & 328 & 550 & 453 & & & & & & & & \\
\hline 1992 & 331 & 350 & 279 & & & & & & & & \\
\hline 1993 & 419 & 566 & 416 & & & & & & & & \\
\hline 1994 & 347 & 421 & 348 & & & & & & & & \\
\hline $\begin{array}{l}\text { TOTAL } \\
\text { Flow }\end{array}$ & hes & 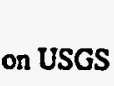 & 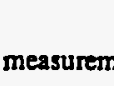 & $\begin{array}{l}1.4 \times 10^{2} \\
\text { ents and Hay }\end{array}$ & $\begin{array}{l}7.3 \times 10^{0} \\
\text { s, } 1991 .\end{array}$ & $1.6 \times 10^{-2}$ & $1.1 \times 10^{-1}$ & $4.2 \times 10^{-1}$ & $8.3 \times 10^{-1}$ & $1.1 \times 10^{3}$ & $1.1 \times 10^{3}$ \\
\hline
\end{tabular}


Assessment of Activation Products

in the Savannah River Site Environment (U)

Table 5-9. Maximally Exposed Individual Drinking Water Doses at Beaufort-Jasper and Port Wentworth

\begin{tabular}{|c|c|c|c|c|c|c|c|c|c|c|}
\hline \multirow{3}{*}{$\begin{array}{l}\text { Year } \\
1954\end{array}$} & \multicolumn{5}{|c|}{ Beaufor-Jasper Max Ind (mrem) } & \multicolumn{5}{|c|}{ Port Wentworth Max Ind (mrem) } \\
\hline & P-32 & CI-5T & Co-60 & $\mathrm{Zn}-65$ & Total & P-32 & Cr-5I & Co-60 & $\mathrm{Zn-65}$ & Total \\
\hline & & & & & & & & $1.4 \times 10^{-4}$ & & $1.4 \times 10^{-4}$ \\
\hline 1955 & & & & & & & & $6.2 \times 10^{-4}$ & & $6.2 \times 10^{-4}$ \\
\hline 1956 & & & & & & & & $1.6 \times 10^{-3}$ & & $1.6 \times 10^{-3}$ \\
\hline 1957 & & & & & & & & $3.3 \times 10^{-3}$ & & $3.3 \times 10^{-3}$ \\
\hline 1958 & & & & & & & & $1.6 \times 10^{-3}$ & & $1.6 \times 10^{-3}$ \\
\hline 1959 & & & & & & & & $4.5 \times 10^{-3}$ & & $4.5 \times 10^{-3}$ \\
\hline 1960 & & & & & & & $4.4 \times 10^{-4}$ & $9.9 \times 10^{-3}$ & $2.80 \times 10^{-3}$ & $1.3 \times 10^{-2}$ \\
\hline 1961 & & & & & & & $2.8 \times 10^{-3}$ & $9.8 \times 10^{-3}$ & $1.60 \times 10^{-2}$ & $2.9 \times 10^{-2}$ \\
\hline 1962 & & & & & & & $1.0 \times 10^{-2}$ & $2.0 \times 10^{-2}$ & $2.60 \times 10^{-2}$ & $5.6 \times 10^{-2}$ \\
\hline 1963 & & & & & & & $5.7 \times 10^{-2}$ & $7.6 \times 10^{-3}$ & $2.70 \times 10^{-2}$ & $9.2 \times 10^{-2}$ \\
\hline 1964 & & & & & & $7.0 \times 10^{-4}$ & $2.6 \times 10^{-2}$ & $2.6 \times 10^{-3}$ & $8.50 \times 10^{-3}$ & $3.8 \times 10^{-2}$ \\
\hline 1965 & $2.8 \times 10^{-3}$ & $1.7 \times 10^{-2}$ & $8.0 \times 10^{-3}$ & $3.5 \times 10^{-3}$ & $3.2 \times 10^{-2}$ & $5.0 \times 10^{-3}$ & $3.0 \times 10^{-2}$ & $1.4 \times 10^{-2}$ & $6.10 \times 10^{-3}$ & $5.5 \times 10^{-2}$ \\
\hline 1966 & $3.3 \times 10^{-3}$ & $2.1 \times 10^{-2}$ & $5.8 \times 10^{-3}$ & $4.5 \times 10^{-3}$ & $3.5 \times 10^{-2}$ & $4.3 \times 10^{-3}$ & $2.8 \times 10^{-2}$ & $7.5 \times 10^{-3}$ & $5.90 \times 10^{-3}$ & $4.6 \times 10^{-2}$ \\
\hline 1967 & $1.1 \times 10^{-3}$ & $6.9 \times 10^{-3}$ & $1.6 \times 10^{-3}$ & $3.6 \times 10^{-3}$ & $1.3 \times 10^{-2}$ & $1.8 \times 10^{-3}$ & $1.2 \times 10^{-2}$ & $2.7 \times 10^{-3}$ & $6.00 \times 10^{-3}$ & $2.2 \times 10^{-2}$ \\
\hline 1968 & $8.7 \times 10^{-4}$ & $3.3 \times 10^{-3}$ & $2.3 \times 10^{-3}$ & $3.0 \times 10^{-3}$ & $9.4 \times 10^{-3}$ & $1.2 \times 10^{-3}$ & $4.5 \times 10^{-3}$ & $3.2 \times 10^{-3}$ & $4.10 \times 10^{-3}$ & $1.3 \times 10^{-2}$ \\
\hline 1969 & $2.0 \times 10^{-4}$ & $1.9 \times 10^{-3}$ & $2.0 \times 10^{-4}$ & $7.6 \times 10^{-4}$ & $3.1 \times 10^{-3}$ & $3.1 \times 10^{-4}$ & $3.1 \times 10^{-3}$ & $3.2 \times 10^{-4}$ & $1.20 \times 10^{-3}$ & $5.0 \times 10^{-3}$ \\
\hline 1970 & $1.7 \times 10^{-4}$ & $3.7 \times 10^{-4}$ & $1.3 \times 10^{-4}$ & $2.1 \times 10^{-4}$ & $8.7 \times 10^{-4}$ & $4.4 \times 10^{-4}$ & $9.7 \times 10^{-4}$ & $3.5 \times 10^{-4}$ & $5.40 \times 10^{-4}$ & $2.3 \times 10^{-3}$ \\
\hline 1971 & $1.2 \times 10^{-4}$ & $1.1 \times 10^{-4}$ & $2.2 \times 10^{-3}$ & $4.4 \times 10^{-4}$ & $2.9 \times 10^{-3}$ & $4.0 \times 10^{-4}$ & $3.4 \times 10^{-4}$ & $7.2 \times 10^{-3}$ & $1.40 \times 10^{-3}$ & $9.4 \times 10^{-3}$ \\
\hline 1972 & $6.5 \times 10^{-5}$ & $3.2 \times 10^{-5}$ & $1.4 \times 10^{-4}$ & & $2.4 \times 10^{-4}$ & $1.3 \times 10^{-4}$ & $6.1 \times 10^{-5}$ & $2.7 \times 10^{-4}$ & & $4.5 \times 10^{-4}$ \\
\hline 1973 & $3.4 \times 10^{-5}$ & $1.2 \times 10^{-5}$ & $2.5 \times 10^{-5}$ & & $7.1 \times 10^{-5}$ & $4.8 \times 10^{-5}$ & $1.7 \times 10^{-5}$ & $3.5 \times 10^{-5}$ & & $9.9 \times 10^{-5}$ \\
\hline 1974 & $3.7 \times 10^{-6}$ & $1.7 \times 10^{-5}$ & $9.3 \times 10^{-7}$ & $6.8 \times 10^{-5}$ & $8.9 \times 10^{-5}$ & $6.3 \times 10^{-6}$ & $2.9 \times 10^{-5}$ & $1.6 \times 10^{-6}$ & $1.20 \times 10^{-4}$ & $1.5 \times 10^{-4}$ \\
\hline 1975 & $3.8 \times 10^{-7}$ & $2.4 \times 10^{-6}$ & $6.1 \times 10^{-6}$ & $7.1 \times 10^{-7}$ & $9.6 \times 10^{-6}$ & $6.2 \times 10^{-7}$ & $3.8 \times 10^{-6}$ & $1.0 \times 10^{-5}$ & $1.20 \times 10^{-6}$ & $1.6 \times 10^{-5}$ \\
\hline 1976 & $2.9 \times 10^{-6}$ & $6.4 \times 10^{-6}$ & $1.2 \times 10^{-6}$ & & $1.0 \times 10^{-5}$ & $6.0 \times 10^{-6}$ & $1.4 \times 10^{-5}$ & $2.5 \times 10^{-6}$ & & $2.2 \times 10^{-5}$ \\
\hline 1977 & $1.9 \times 10^{-6}$ & $2.1 \times 10^{-5}$ & $1.1 \times 10^{-4}$ & & $1.3 \times 10^{-4}$ & $2.5 \times 10^{-6}$ & $2.7 \times 10^{-5}$ & $1.4 \times 10^{-4}$ & & $1.7 \times 10^{-4}$ \\
\hline 1978 & & $1.0 \times 10^{-6}$ & $3.4 \times 10^{-7}$ & & $1.4 \times 10^{-6}$ & $\cdot$ & $2.2 \times 10^{-6}$ & $7.2 \times 10^{-7}$ & & $2.9 \times 10^{-6}$ \\
\hline 1979 & $6.8 \times 10^{-7}$ & $9.7 \times 10^{-6}$ & $2.5 \times 10^{-4}$ & & $2.6 \times 10^{-4}$ & $1.4 \times 10^{-6}$ & $1.9 \times 10^{-5}$ & $4.9 \times 10^{-4}$ & & $5.1 \times 10^{-4}$ \\
\hline 1980 & & & $1.1 \times 10^{-6}$ & & $1.1 \times 10^{-6}$ & & & $1.9 \times 10^{-6}$ & & $1.9 \times 10^{-6}$ \\
\hline 1981 & & & $4.3 \times 10^{-7}$ & & $4.3 \times 10^{-7}$ & & & $5.9 \times 10^{-7}$ & & $5.9 \times 10^{-7}$ \\
\hline 1982 & & & $1.2 \times 10^{-7}$ & & $1.2 \times 10^{-7}$ & & & $2.3 \times 10^{-7}$ & & $2.3 \times 10^{-7}$ \\
\hline 1983 & & & $3.1 \times 10^{-6}$ & & $3.1 \times 10^{-6}$ & & & $2.7 \times 10^{-6}$ & & $2.7 \times 10^{-6}$ \\
\hline 1984 & & & $2.5 \times 10^{-7}$ & & $2.5 \times 10^{-7}$ & & & $3.8 \times 10^{-7}$ & & $3.8 \times 10^{-7}$ \\
\hline 1985 & & . & & & & & & & & \\
\hline 1986 & & & & & & & & & & \\
\hline 1987 & & & & & & & & & & \\
\hline 1988 & & & & & & & & & & \\
\hline 1989 & & & & & & & & & & \\
\hline 1990 & & & & & & & & & & \\
\hline 1991 & & & & & & & & & & \\
\hline 1992 & & & & & & & & & & \\
\hline 1993 & & & & & & & & & & \\
\hline 1994 & & & & & & & & & & \\
\hline DTAL & $8.7 \times 10^{-3}$ & $5.1 \times 10^{-2}$ & $2.1 \times 10^{-2}$ & $1.6 \times 10^{-2}$ & $9.7 \times 10^{-2}$ & $1.4 \times 10^{-2}$ & $1.8 \times 10^{-1}$ & $9.8 \times 10^{-2}$ & $1.1 \times 10^{-1}$ & $3.9 \times 10^{-1}$ \\
\hline
\end{tabular}




\section{Chromium-51}

The maximum annual dose occurred in 1963. The effective dose equivalent to the maximally exposed individual for that year has been estimated as $0.072 \mathrm{mrem}$. If the hypothetical "maximum" exposure conditions are used as the bounding case for the 40-year period of site operations considered here, the cumulative effective dose to such an individual would be about $0.22 \mathrm{mrem}$. Approximately $84 \%$ of this dose is from eating fish from the Savannah River, and most of the remainder is from drinking untreated river water.

\section{Cobalt 60}

The maximum annual dose occurred in 1962 . The effective dose equivalent to the maximally exposed individual for that year has been estimated as $0.09 \mathrm{mrem}$. If the hypothetical "maximum" exposure conditions are used as the bounding case for the 40-year period of site operations considered here, the cumulative effective dose to such an individual would be about $0.44 \mathrm{mrem}$. This dose is almost equally due to eating fish from the Savannah River, drinking untreated river water, and being exposed on the shoreline to energetic gamma rays.

\section{Zinc-65}

The maximum rahntual dose occurred in 1962 and 1963. The effective dose equivalent to the maximally exposed individual for those years has been estimated as $1.8 \mathrm{mrem}$. If the hypothetical "maximum" exposure conditions are used as the bounding case for the 40-year period of site operations considered here, the cumulative effective dose to such an individual would be about $7.3 \mathrm{mrem}$. More than $99 \%$ of this dose is due to eating fish from the Savannah River, and most of the remainder is from drinking untreated river water.

\section{Sum of All Doses}

The maximally exposed indivudual dose from the sum of the individual radionuclide doses is $54 \mathrm{mrem}$. Because this individual's dose from non-SRS sources of radiation for that same time period would have exceeded 14,000 mrem, it may be concluded that the contribution to downstream individual doses by SRS activation product releases is a tiny fraction of the total dose.

\section{Collective Doses from Liquid Releases}

Collective or population doses to residents who drink Savannah River water, eat fish from the river, and eat saltwater invertebrates from the Savannah River estuary are reported in Tables 5-5 through 5-8.
Drinking water doses for users of the Beaufort-Jasper (50,000 customers) and Port Wentworth, (15,000 effective consumers) water treatment plants also have been estimated. Different terminology is used to describe the two populations to reflect the difference in their compositions (Hamby 1991). The Beaufort-Jasper plant services residential areas and therefore provides full-scale domestic water service. The Port Wentworth facility serves a commercial complex in which contact with treated Savannah River water is currently limited to industrial workers who consume tap water.

If the cumulative effective doses received by both water treatment plant populations are summed, the collective dose equivalent would be about 3.7 person-rem. Using the ICRP nominal risk factor, the predicted impact of this collective dose is an estimated 0.002 excess fatal cancers in a population of 65,000 people- 10,400 of whom, at the current fatal cancer rate, are projected to succumb to cancer from all other sources.

The total population dose for liquid releases is the sum of the dose from the water treatment plant pathway (3.7 person-rem, 65,000 people) plus the dose due to other liquid pathways such as fish (1,250 person-rem, 550,000 people). The collective dose equivalent is 1254 person-rem distributed among 615,000 people. The nominal risk factor predicts 0.6 fatal cancers in a population of 615,000 people98,000 of whom will die of cancer from other sources.

\section{Comparisons of Activation Product Doses Near SRS with Applicable Regulations}

\section{Atmospheric Releases}

The highest hypothetical annual effective dose received by the maximally exposed individual because of atmospheric releases of ${ }^{60} \mathrm{Co}$ from SRS was $0.4 \mathrm{mrem}$ in 1968 (Table 5-4). The current DOE and EPA annual limit for dose to members of the public because of atmospheric releases is $10 \mathrm{mrem}$ (DOE 1990; and EPA 1989a).

\section{Liquid Releases}

Activation product doses from drinking water sources are evaluated based on the DOE and EPA annual drinking water standard of 4 mrem (DOE 1990; and EPA 1977). As shown in Table 5-9, at no time during site operations has a drinking water dose from SRS activation product releases 
to the Savannah River exceeded $0.1 \mathrm{mrem}$. The maximum dose was 0.09 mrem for Port Wentworth in 1963. It is important to note that the dose limits described above are meant to be applied to all releases of radioactivity not just activation products. When the calculations are expanded to include all radionuclide releases, the relationship between SRS doses and the EPA dose limits described above remains valid. SRS, based on activation product or total releases, consistently is a minor contributor to radiation dose in the SRS environment.

\section{Summary of Dosimetric Impacts}

The overall radiological impact of SRS activation product releases (1954-1994) on the offsite maximally exposed individual can be characterized by total doses of $0.76 \mathrm{mrem}$ (atmospheric) and $54 \mathrm{mrem}$ (liquid). During this same period, however, such an individual received a dose of approximately 14,000 mrem from other sources of ionizing radiation present in the environment.

The impact of SRS activation product releases on offsite populations also has been evaluated. The total collective dose from atmospheric activation product releases (1954 1994) is estimated as 1.0 person-rem, distributed among 555,100 individuals. The total collective dose from liquid activation product releases for the same period was 1254 person-rem, distributed among the 555,100 individuals listed above and an additional 65,000 individuals who get their drinking water from the Savannah River. These collective doses are minor components of the doses received from other environmental sources.

Activation product releases from SRS have decreased dramatically in the last decade of site operations and present a negligible risk to the offsite environment and the population it supports.

\section{References}

Amett, M.W., L. K. Karapatakis and A. R. Mamatey, 1994, Savannah River Site Environmental Report for 1993. WSRC-TR-94-075, p. 79, Westinghouse Savannah River Company, Aiken, SC.

Bauer, L. R., 1991, Modeling Chronic Almospheric Releases at the SRS: Evaluation and Verification of XOQ$D O Q(U)$, WSRC-RP-91-320, Westinghouse Savannah River Company, Aiken, SC.
Cooper, R. E., 1975, Computer Programs at SRL to Evaluate Environmental Effects of SRP Operations and Postulated Accidental Releases, DPST-75-384, Savannah River Laboratory, Aiken, SC.

DOE (U.S. Department of Energy), 1988, Internal Dose Conversion Factors for Calculation of Dose to the Public, DOE/EH-0071, Washington, DC.

DOE, 1990, Radiation Protection of the Public and Environment, DOE Order 5400.5, Washington, DC.

Eckerman, K. F., F. J. Congel, A. K. Roecklein, and W. J. Pasciak, 1980, User's Guide to GASPAR Code, NUREG0597, U. S. Nuclear Regulatory Commission, Washington, DC.

EPA (U. S. Environmental Protection Agency), 1977, National Interim Primary Drinking Water Regulations, EPA 570/9-76-003, Washington, DC.

EPA, 1989a, National Emission Standards for Emissions of Radionuclides Other than Radon from Department of Energy Facilities, 40 CFR, Part 61, Subpart H, Washington, DC.

EPA, 1989b, National Emission Standards for Hazardous Air Pollutants; Regulation of Radionuclides; Final Rule and Notice of Reconsideration, 40 CFR Part 61, Federal Register, Vol. 54, No. 240, Washington, DC.

Hamby, D. M., 1991, Land and Water Use Characteristics in the Vicinity of the Savannah River Site (U), WSRC-RP91-17, Westinghouse Savannah River Company, Aiken, SC.

Hamby, D. M., and M. J. Parker, 1991, Gaussian Dispersion and Dosimetric Modeling Sensitivity to Area-specific 1982-1986 Meteorological Data Collected at the Savannah River Site (U), WSRC-RP-91-909, Westinghouse Savannah River Company, Aiken, SC.

Hamby, D. M., 1992, Verification of the GASPAR Dose Assessment Module Used in MAXIGASP and POPGASP, WSRC-RP-92-418, Westinghouse Savannah River Company, Aiken, SC.

Hamby, D. M., 1995, Verification of the MAXIGASP and POPGASP Computer Codes for Environmental Dose Assessment, WSRC-RP-94-522, Westinghouse Savannah River Company, Aiken, SC. 
ICRP, 1979, International Commission on Radiological Protection. Limits for Intake of Radionuclides by Workers, Oxford: Pergamon Press; ICRP Publication 30, Part 1.

ICRP, 1989, International Commission on Radiological Protection. Age-Dependent Doses to Members of the Public from Radionuclides, Oxford: Pergamon Press; ICRP Publication 56.

ICRP, 1991, International Commission on Radiological Protection, Risks Associated with Ionizing Radiations, Oxford: Pergamon Press; ICRP Vol. 22, No. 1.

Marter, W. L., 1984, Environmental Dosimetry for Normal Operations at SRP, DPST-83-270, Rev. 1, Savannah River Laboratory, Aiken, SC.

NRC (U. S. Nuclear Regulatory Commission), 1977a, Methods for Estimating Atmospheric Transport and Dispersion of 'Gaseous Effluents in Routine Releases from Light-Water-Cooled Reactors, Regulatory Guide 1.111, Rev. 1, Washington, DC.

NRC, 1977b, Calculation of Annual Doses to Man from Routine Releases of Reactor Effluents for the Purpose of Evaluating Compliance with 10 CFR Part 50, Appendix I, Regulatory Guide 1.109, Rev. 1, Washington, DC.

Sagendorf, J. F., J. T. Goll, and W. F. Sandusky, 1982, XOQDOQ: Computer Program for the Meteorological Evaluation of Routine Effluent Releases at Nuclear Power Stations, NUREG/CR-2919, U.S. Nuclear Regulatory Commission, Washington, DC.

Simpson, D. B., and B. L. McGill, 1980, Users Manual for LADTAP II - A Computer Program for Calculating Radiation Exposure to Man from Routine Releases of Nuclear Reactor Effluents, NUREG/CR-1276, ORNI/TDMC-1, Oak Ridge National Laboratory, Oak Ridge, TN.

WSRC, 1994, Savannah River Site Environmental Report for 1993, Summary Report, WSRC-TR-94-076, Westinghouse Savannah River Company, Aiken, SC, p. 6.

\section{Additional Reading}

The following documents in the Radiological Assessment Program series are available to the public from National Technical Information Service

\section{U.S. Department of Commerce 5285 Port Royal Road Springfield, VA 22161}

Assessment of Radiocarbon in the Savannah River Site Environment WSRC-TR-93-215

Cesium in the Savannah River Site Environment WSRC-RP-92-250

Radioiodine in the Savannah River Site Environment WSRC-RP-90-424-2

Assessment of Mercury in the Savannah River Site Environment WSRC-TR-94-0218-ET

Assessment of Noble Gases in the Savannah River Site Environment WSRC-TR-95-219

Assessment of Plutonium in the Savannah River Site Environment WSRC-RP-92-879, Rev 1

Assessment of Strontium in the Savannah River Site Environment WSRC-RP-92-984

Assessment of Technetium in the Savannah River Site Environment WSRC-TR-93-217

Assessment of 'Tritium in the Savannah River Site Environment WSRC-TR-93-214

Uranium in the Savannah River Site Environment WSRC-RP-92-315 
